VILNIAUS GEDIMINO TECHNIKOS UNIVERSITETAS

Donatas UZNYS

\title{
NERAIŠKIĄJA LOGIKA GRĮSTAS ŠEŠIAFAZIŲ ASINCHRONINIŲ PAVARŲ VALDYMAS
}

DAKTARO DISERTACIJA

TECHNOLOGIJOS MOKSLAI,

ELEKTROS IR ELEKTRONIKOS INŽINERIJA (01T)

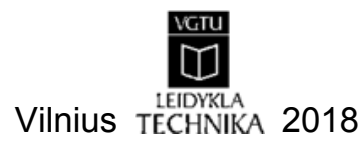


Disertacija rengta 2013-2018 metais Vilniaus Gedimino technikos universitete.

Vadovas

doc. dr. Saulius LISAUSKAS (Vilniaus Gedimino technikos universitetas, elektros ir elektronikos inžinerija - 01T).

Vilniaus Gedimino technikos universiteto Elektros ir elektronikos inžinerijos mokslo krypties disertacijos gynimo taryba:

\section{Pirmininkas}

prof. dr. Algirdas BAŠKYS (Vilniaus Gedimino technikos universitetas, elektros ir elektronikos inžinerija - 01T).

\section{Nariai:}

dr. Adam IDZKOWSKI (Balstogès technologijos universitetas, Lenkija, elektros ir elektronikos inžinerija - 01T),

dr. Robertas LUKOČIUS (Kauno technologijos universitetas, elektros ir elektronikos inžinerija - 01T),

doc. dr. Tomas LUNECKAS (Vilniaus Gedimino technikos universitetas, elektros ir elektronikos inžinerija - 01T),

prof. dr. Voitech STANKEVIČ (Valstybinis mokslinių tyrimų institutas Fizinių ir technologijos mokslų centras, fizika - 02P).

Disertacija bus ginama viešame Elektros ir elektronikos inžinerijos mokslo krypties disertacijos gynimo tarybos posėdyje 2018 m. liepos 13 d. 9 val. Vilniaus Gedimino technikos universiteto senato posėdžių salèje.

Adresas: Sauletekio al. 11, LT-10223 Vilnius, Lietuva.

Tel.: (8 5) 274 4956; faksas (8 5) 270 0112; el. paštas doktor@vgtu.lt

Pranešimai apie numatomą ginti disertaciją išsiųsti 2018 m. birželio $12 \mathrm{~d}$.

Disertaciją galima peržiūreti VGTU talpykloje http://dspace.vgtu.lt ir Vilniaus Gedimino technikos universiteto bibliotekoje (Saulètekio al. 14, LT-10223 Vilnius, Lietuva) bei Lietuvos mokslų akademijos Vrublevskių bibliotekoje (Žygimantų g. 1, LT-01102 Vilnius, Lietuva).

VGTU leidyklos TECHNIKA 2018-030-M mokslo literatūros knyga http://leidykla.vgtu.lt

ISBN 978-609-476-117-1

(C) VGTU leidykla TECHNIKA, 2018

(C) Donatas Uznys, 2018

donatas.uznys@vgtu.lt 
VILNIUS GEDIMINAS TECHNICAL UNIVERSITY

Donatas UZNYS

FUZZY LOGIC BASED SIX-PHASE INDUCTION DRIVE CONTROL

DOCTORAL DISSERTATION

TECHNOLOGICAL SCIENCES,

ELECTRICAL AND ELECTRONIC ENGINEERING (01T)

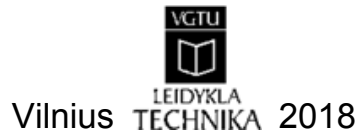


Doctoral dissertation was prepared at Vilnius Gediminas Technical University in 2013-2018.

\section{Supervisor}

Assoc. Prof. Dr Saulius LISAUSKAS (Vilnius Gediminas Technical University, Electrical and Electronic Engineering - 01T).

The Dissertation Defence Council of Scientific Field of Electrical and Electronic Engineering of Vilnius Gediminas Technical University:

\section{Chairman}

Prof. Dr Algirdas BAŠKYS (Vilnius Gediminas Technical University, Electrical and Electronic Engineering - 01T).

\section{Members:}

Dr Adam IDZKOWSKI (Bialystok University of Technology, Poland, Electrical and Electronic Engineering - 01T),

Dr Robertas LUKOČIUS (Kaunas University of Technology, Electrical and Electronic Engineering - 01T),

Assoc. Prof. Dr Tomas LUNECKAS (Vilnius Gediminas Technical University, Electrical and Electronic Engineering - 01T),

Prof. Dr Voitech STANKEVIČ (State Research Institute Center for Physical Sciences and Technology, Physics - 02P).

The dissertation will be defended at the public meeting of the Dissertation Defence Council of Electrical and Electronic Engineering in the Senate Hall of Vilnius Gediminas Technical University at 9 a. m. on 13 July 2018.

Address: Saulètekio al. 11, LT-10223 Vilnius, Lithuania.

Tel.: +370 5274 4956; fax +370 5270 0112; e-mail: doktor@vgtu.lt

A notification on the intend defending of the dissertation was sent on 12 June 2018.

A copy of the doctoral dissertation is available for review at VGTU repository http://dspace.vgtu.lt and at the Library of Vilnius Gediminas Technical University (Sauletekio al. 14, LT-10223 Vilnius, Lithuania) and the Wroblewski Library of the Lithuanian Academy of Sciences (Žygimantų g. 1, LT-01102 Vilnius, Lithuania). 


\section{Reziumè}

Disertacijoje nagrinėjama šešiafazio asinchroninio variklio, dirbančio normaliuoju ir poavariniu režimu, valdymo problema, taikant neraiškiosios logikos valdiklius. Darbo tikslas - sukurti šešiafazių asinchroninių pavarų valdymo būdus, naudojančius neraiškiosios logikos reguliatorius bei gebančius pagerinti statoriaus srovių ir magnetinio srauto kokybinius rodiklius.

Darbe sprendžiami uždaviniai: daugiafazių asinchroninių variklių matematinių ir kompiuterinių modelių sudarymas; eksperimentinis šešiafazio variklio pereinamujų vyksmų, esant normaliajam ir poavariniam darbo režimams, tyrimas; šešiafazių elektros pavarų su šešiafaziu įtampos inverteriu tyrimas modeliuojant; šešiafazès asinchroninès dažninės pavaros eksperimentinis poavarinio režimo padarinių kompensavimo tyrimas.

Disertaciją sudaro įvadas, trys skyriai, bendrosios išvados, naudotos literatūros ir autoriaus publikacijų disertacijos tema sąrašai ir trys priedai.

Ivadiniame skyriuje aptariama tiriamoji problema, darbo aktualumas, aprašomas tyrimų objektas, formuluojamas darbo tikslas bei uždaviniai, aprašoma tyrimų metodika, darbo mokslinis naujumas, darbo rezultatų praktinè reikšmė, ginamieji teiginiai. Ivado pabaigoje pristatomos disertacijos tema autoriaus paskelbtos publikacijos ir pranešimai konferencijose bei disertacijos struktūra.

Pirmajame skyriuje pateikta literatūros analizè. Jame apžvelgiami daugiafazių asinchroninių variklių privalumai ir trūkumai, jų taikymo atvejai, apžvelgti šių variklių gedimai, jų pasekmių kompensavimo metodai. Pristatyti daugiafazių asinchroninių dažninių pavarų valdymo metodai ir šešiafazių asinchroninių variklių matematiniai modeliai. Skyriaus pabaigoje formuluojamos išvados ir tikslinami disertacijos uždaviniai.

Antrajame skyriuje pateikti imitaciniai šešiafazio asinchroninio variklio ir dažninès pavaros bandymų rezultatai, sukurtas vektorinis valdymas naudojantis neraiškiosios logikos reguliatorių.

Trečiajame skyriuje aprašytas eksperimentinių bandymų stendas poavariniam režimui tirti, ištirtas vienos trūkstamos statoriaus fazès poavarinio režimo padarinių kompensavimas skaliariniu pavaros valdymo būdu, jo taikymui sukurtas formuojamų statoriaus įtampos fazinių kampų paieškos algoritmas ir šiuos kampus pritaikantis reguliatorius pavarai.

Disertacijos tema paskelbti 4 straipsniai: vienas - mokslo žurnale, įtrauktame i Clarivate Analytics Web of Science duomenų bazę, vienas - Clarivate Analytics Web of Science duomenų bazès Proceedings leidiniuose ir du - moksliniuose žurnaluose, cituojamose kitose duomenų bazèse. Disertacijos tema perskaityti 9 pranešimai konferencijose. 


\section{Abstract}

The dissertation investigates the issues of six-phase induction motor in normal operating and post-fault conditions using fuzzy logic controllers. The main aim of research is to develop six-phase induction drive control methods using fuzzy logic controllers that can improve qualities of stator currents and magnetic flux production.

The work approaches the following tasks: creation of multi-phase induction machine mathematical and computer models; experimental studies of six-phase machine transients in normal operating and post-fault conditions; simulation studies of six-phase electric drives with six-phase voltage source inverter; experimental studies of six-phase induction frequency drive in compensated post-fault conditions.

The dissertation consists of three parts including introduction, three chapters, general conclusions, references and three annexes.

The introduction reveals the investigated problem, importance of the thesis and the object of research and describes the purpose and tasks of the thesis, research methodology, scientific novelty, the practical significance of results examined in the thesis and defended statements. The introduction ends in presenting the author's publications and conference presentations on the subject of the defended dissertation and defining the structure of the dissertation.

Chapter 1 revises used literature. Advantages and disadvantages of multiphase induction motors, their application, faults, compensation methods for fault aftereffects are discussed. Control methods of multi-phase induction drives and mathematical models of six-phase induction drives are presented. At the end of the chapter, conclusions are drawn and the tasks for the dissertation are reconsidered.

Chapter 2 presents simulation results of six-phase induction motor and frequency drive operation. Fuzzy logic controller for vector control method is developed.

Chapters 3 presents experimental rig for testing in post-fault conditions, investigates one phase loss post-fault condition after-effects compensation using scalar control method. For this purpose, a search algorithm for stator voltage phase angles and controller for their application is developed.

4 articles focusing on the subject of the discussed dissertation are published: one article - in the Clarivate Analytics Web of Science database, one - in Clarivate Analytics Web of Science database Proceedings material, two articles - in journals quoted by other data bases. 9 presentations on the subject have been given in conferences. 


\section{Žymëjimai}

\section{Simboliai}

A - statoriaus A fazè;

B - statoriaus B fazé;

C - statoriaus C fazé;

D - statoriaus D fazé;

E - statoriaus E fazé;

F - statoriaus F faze;

a - rotoriaus a fazé;

b - rotoriaus b fazé;

c - rotoriaus c fazé;

$i_{\mathrm{A}}$ - statoriaus A fazès srovè;

$i_{\mathrm{B}}$ - statoriaus B fazès srovė;

$i_{\mathrm{C}}$ - statoriaus $\mathrm{C}$ fazès srovė;

$i_{\mathrm{D}}$-statoriaus D fazès srovė; 
$i_{\mathrm{E}}-$ statoriaus E fazès srove;

$i_{\mathrm{F}}$ - statoriaus $\mathrm{F}$ fazès srovè;

$i_{\mathrm{a}}$ - rotoriaus a fazès srové;

$i_{\mathrm{b}}$ - rotoriaus b fazès srovè;

$i_{c}$ - rotoriaus c fazès srovè;

$i_{\alpha s}$ - statoriaus srovès projekcija ị $\alpha$ aši

$i_{\beta s}-$ statoriaus srovès projekcija i $\beta$ ašį;

$i_{\mathrm{ds}}-$ statoriaus srovės projekcija ị d aši;

$i_{\mathrm{qs}}$ - statoriaus srovės projekcija ị q ašį;

$i_{\alpha r}-$ rotoriaus srovès projekcija ị $\alpha$ ašįi;

$i_{\beta r}$ - rotoriaus srovès projekcija ị $\beta$ ašį;

$i_{\mathrm{dr}}$ - rotoriaus srovès projekcija ị d ašį;

$i_{\mathrm{qr}}$ - rotoriaus srovès projekcija ị q ašị;

$J$ - variklio rotoriaus inercijos momentas;

$L_{\mathrm{A}}$ - statoriaus A fazinès apvijos savasis induktyvumas;

$L_{\mathrm{B}}$ - statoriaus B fazinès apvijos savasis induktyvumas;

$L_{\mathrm{C}}$ - statoriaus C fazinès apvijos savasis induktyvumas;

$L_{\mathrm{D}}$ - statoriaus D fazinès apvijos savasis induktyvumas;

$L_{\mathrm{E}}-$ statoriaus $\mathrm{E}$ fazinès apvijos savasis induktyvumas;

$L_{\mathrm{F}}$ - statoriaus F fazinès apvijos savasis induktyvumas;

$L_{\mathrm{ls}}$ - statoriaus apvijų sklaidos induktyvumas;

$L_{\operatorname{lm}}$ - abipusis statoriaus apvijų sklaidos induktyvumas;

$L_{\mathrm{lr}}$ - rotoriaus apvijų sklaidos induktyvumas;

$L_{\mathrm{m}}$ - abipusis statoriaus ir rotoriaus apvijų induktyvumas;

$M_{\mathrm{e}}$ - asinchroninio variklio elektromagnetinis momentas;

viii 
$M_{\text {st }}$ - statinis apkrovos momentas;

$n$ - daugiafazio elektros variklio statoriaus fazių skaičius;

$R_{\mathrm{A}}$ - statoriaus A fazinès apvijos varža;

$R_{\mathrm{B}}$ - statoriaus B fazinès apvijos varža;

$R_{\mathrm{C}}$ - statoriaus C fazinès apvijos varža;

$R_{\mathrm{D}}$ - statoriaus D fazinès apvijos varža;

$R_{\mathrm{E}}$ - statoriaus E fazinès apvijos varža;

$R_{\mathrm{F}}$ - statoriaus $\mathrm{F}$ fazinès apvijos varža;

$R_{\mathrm{a}}$ - rotoriaus a fazinès apvijos varža;

$R_{\mathrm{b}}$ - rotoriaus b fazinès apvijos varža;

$R_{\mathrm{c}}$ - rotoriaus c fazinès apvijos varža;

$R_{\mathrm{s}}$ - statoriaus aktyvioji varža;

$u_{\mathrm{A}}$ - statoriaus A fazinès apvijos akimirkinè ịtampa;

$u_{\mathrm{B}}$ - statoriaus B fazinès apvijos akimirkinè ịtampa;

$u_{\mathrm{C}}$ - statoriaus $\mathrm{C}$ fazinès apvijos akimirkinè ịtampa;

$u_{\mathrm{D}}$ - statoriaus D fazinès apvijos akimirkinè ịtampa;

$u_{\mathrm{E}}$-statoriaus E fazinès apvijos akimirkinè ịtampa;

$u_{\mathrm{F}}$ - statoriaus $\mathrm{F}$ fazinès apvijos akimirkinè ịtampa;

$u_{\mathrm{a}}$ - rotoriaus a fazinès apvijos akimirkinè ịtampa;

$u_{\mathrm{b}}$ - rotoriaus b fazinès apvijos akimirkinè įtampa;

$u_{\mathrm{c}}$ - rotoriaus c fazinès apvijos akimirkinè ịtampa;

$u_{\alpha \mathrm{s}}$ - statoriaus įtampos projekcija ị $\alpha$ aši;

$u_{\beta s}$ - statoriaus įtampos projekcija ị $\beta$ ašį;

$u_{\mathrm{ds}}$ - statoriaus ịtampos projekcija ị d ašį;

$u_{\mathrm{qs}}$ - statoriaus ịtampos projekcija ị q aší ; 
$u_{\alpha r}$ - rotoriaus įtampos projekcija ị $\alpha$ aši;

$u_{\beta r}$ - rotoriaus ịtampos projekcija ị $\beta$ ašį;

$u_{\mathrm{dr}}$ - rotoriaus ịtampos projekcija ị d aši;

$u_{\mathrm{qr}}$ - rotoriaus ịtampos projekcija ị q ašị;

$\Psi_{\text {A }}$ - statoriaus A fazinès apvijos surištasis srautas;

$\Psi_{\mathrm{B}}$ - statoriaus B fazinès apvijos surištasis srautas;

$\Psi_{\mathrm{C}}$ - statoriaus $\mathrm{C}$ fazinès apvijos surištasis srautas;

$\Psi_{\mathrm{D}}$ - statoriaus D fazinès apvijos surištasis srautas;

$\Psi_{\mathrm{E}}$ - statoriaus E fazinès apvijos surištasis srautas;

$\Psi_{\mathrm{F}}$ - statoriaus $\mathrm{F}$ fazinès apvijos surištasis srautas;

$\Psi_{\text {a }}$ - rotoriaus a fazinès apvijos surištasis srautas;

$\Psi_{\mathrm{b}}$ - rotoriaus b fazinès apvijos surištasis srautas;

$\Psi_{\mathrm{c}}$ - rotoriaus c fazinès apvijos surištasis srautas;

$\Psi_{\alpha s}$ - statoriaus surištụjų srautų projekcija ị $\alpha$ ašį;;

$\Psi_{\beta s}$ - statoriaus surištujų srautų projekcija ị $\beta$ ašį;

$\Psi_{\mathrm{ds}}$ - statoriaus surištụjų srautų projekcija ị d ašį;;

$\Psi_{\mathrm{qs}}$ - statoriaus surištụjų srautų projekcija ị q ašį;

$\Psi_{\alpha r}$ - rotoriaus surištụjų srautų projekcija ị $\alpha$ aši;

$\Psi_{\beta r}$ - rotoriaus surištujų srautų projekcija ị $\beta$ ašį;

$\Psi_{\mathrm{dr}}$ - rotoriaus surištųjų srautų projekcija ị d ašį;

$\Psi_{\mathrm{qr}}$ - rotoriaus surištujų srautų projekcija ị q ašį;

$\theta_{\mathrm{r}}$ - rotoriaus posūkio kampas;

$\omega_{\mathrm{r}}$ - rotoriaus sukimosi greitis;

$\omega_{\mathrm{e}}-$ dvipolio variklio sinchroninis greitis. 


\section{Santrumpos}

NL - (angl. Fuzzy Logic) neraiškioji logika;

TMV - (angl. Direct Torque Control, DTC) tiesioginis momento valdymas. 



\section{Turinys}

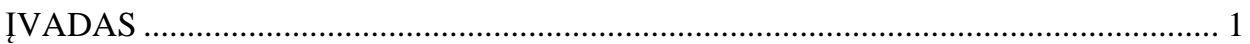

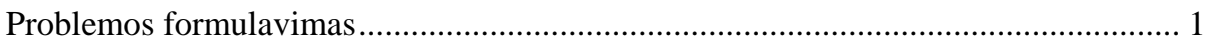

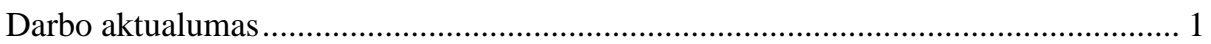

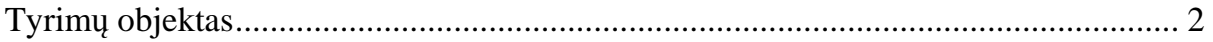

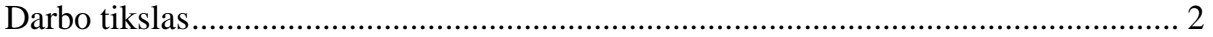

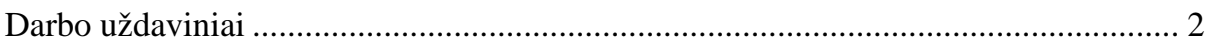

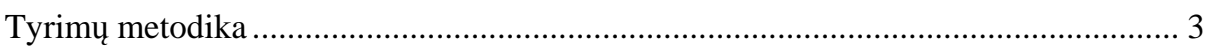

Darbo mokslinis naujumas .................................................................................. 3

Darbo rezultatų praktinė reikšmė ………............................................................. 3

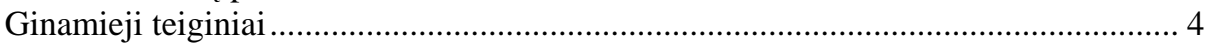

Darbo rezultatu aprobavimas................................................................................... 4

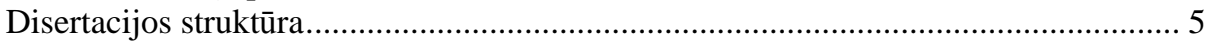

1. DAUGIAFAZIŲ ELEKTROS PAVARŲ APŽVALGA IR ANALIZĖ ......................... 7

1.1. Daugiafazių elektros pavarų taikymo sritys ir konstrukcijos.................................. 7

1.2. Daugiafazio variklio dinaminiai modeliai .......................................................... 18

1.3. Daugiafazių pavaru valdymo metodai ................................................................... 22

1.4. Pirmojo skyriaus išvados ir disertacijos uždavinių formulavimas........................ 29

2. ŠEŠIAFAZIŲ PAVARŲ MODELIAVIMAS IR VALDYMAS ESANT

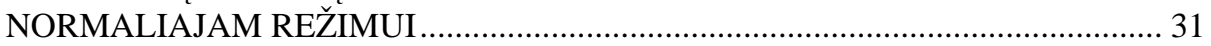

2.1. Imitaciniai šešiafazio variklio ir pavaros bandymai .............................................. 31 
2.2. Vektorinis šešiafazių pavarų valdymas

2.3. Vektorinis šešiafazių pavarų su neraiškiosios logikos reguliatoriais valdymas... 48

2.4. Antrojo skyriaus išvados 56

3. ŠEŠIAFAZIŲ PAVARŲ VALDYMAS ESANT POAVARINIAM REŽIMUI ......... 59

3.1. Eksperimentinis bandymų stendas.................................................................. 59

3.2. Dažninès pavaros normaliojo ir poavarinio režimo tyrimas .................................. 66

3.3. Poavarinio režimo kompensatoriaus sudarymo metodika ..................................... 74

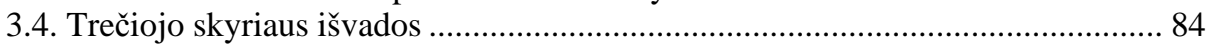

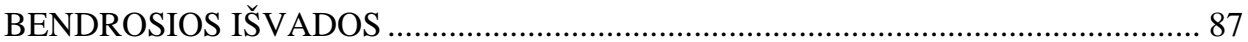

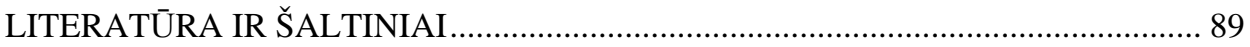

AUTORIAUS MOKSLINIŲ PUBLIKACIJŲ DISERTACIJOS TEMA SĄRAŠAS .... 97

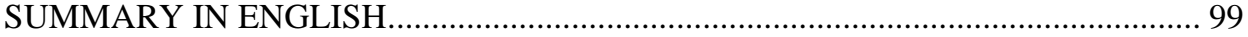

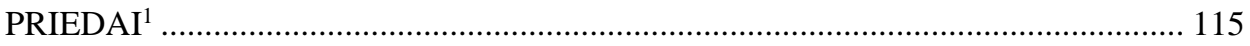

A priedas. Disertacijos autoriaus sąžiningumo deklaracija ..................................... 116

B priedas. Bendraautorių sutikimai teikti publikacijų medžiagą disertacijoje........... 117

C priedas. Autoriaus mokslinių publikacijų disertacijos tema kopijos ....................... 124

${ }^{1}$ Priedai pateikiami pridètoje kompaktinèje plokštelèje.

xiv 


\section{Contents}

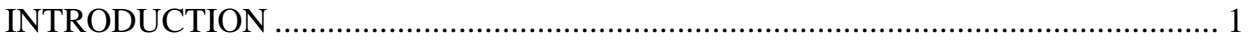

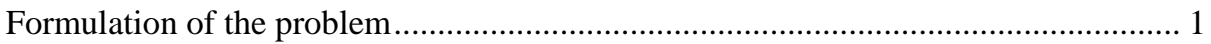

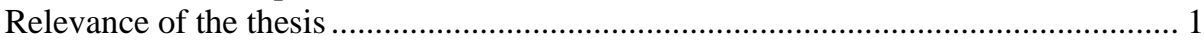

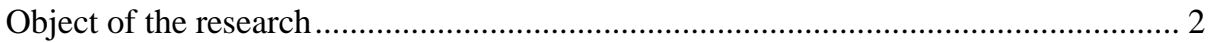

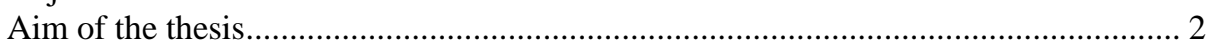

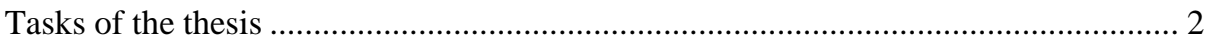

Research methodology ………………..................................................................... 3

Scientific novelty of the thesis .................................................................................. 3

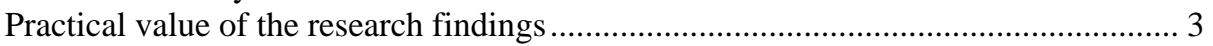

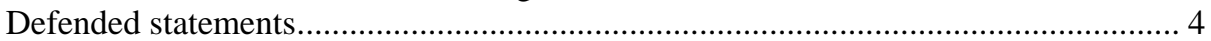

Approval of the research findings ........................................................................... 4

Structure of the disertation .......................................................................................... 5

1. SURVEY AND ANALYSIS OF MULTI-PHASE ELECTRIC DRIVES ………........ 7

1.1. Applications and designs of multi-phase electric drives......................................... 7

1.2. Dynamic models of multi-phase machines......................................................... 18

1.3. Control methods of multi-phase drives.............................................................. 22

1.4. First chapter conclusions and formulation of the thesis objectives ...................... 29

2. SIX-PHASE DRIVE MODELING AND CONTROL IN NORMAL OPERATING

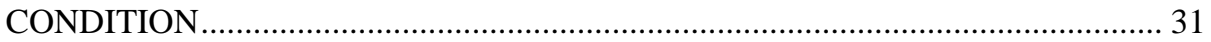

2.1. Simulation of six-phase motor and drive............................................................. 31 
2.2. Vector control of six-phase drives

2.3. Vector control of six-phase drives using fuzzy logic controllers......................... 48

2.4. Second chapter conclusions.................................................................................. 56

3. SIX-PHASE DRIVE CONTROL IN POST-FAULT CONDITIONS ......................... 59

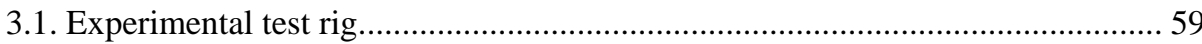

3.2. Normal operating and post-fault conditions of frequency drive ........................... 66

3.3. Compensator for operation in post-fault conditions ............................................ 74

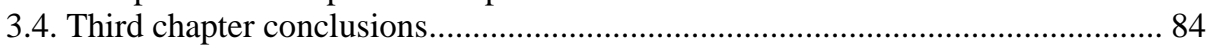

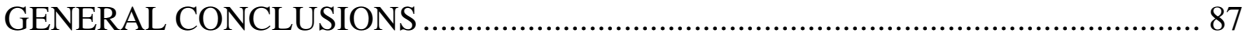

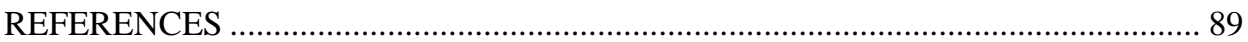

LIST OF THE AUTHOR'S SCIENTIFIC PUBLICATIONS BY THE AUTHOR ON THE TOPIC OF THE DISSERTATION ................................................................... 97

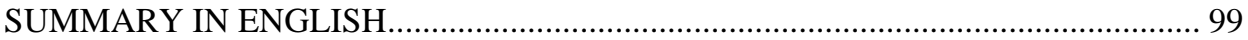

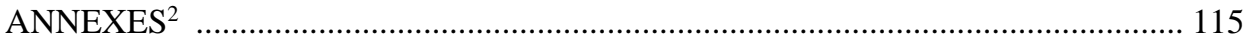

Annex A. Author's declaration of academic integrity ............................................... 116

Annex B. Co-author's agreements to present publications material in the doctoral

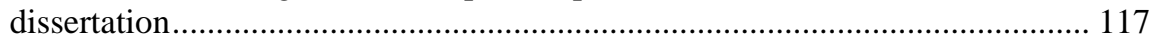

Annex C. Copies of scientific publications by the author on the topic of the dissertation.

${ }^{2}$ The annexes are supplied in the enclosed compact disc. 


\section{Ivadas}

\section{Problemos formulavimas}

Mokslinėje literatūroje vis intensyviau nagrinėjami daugiafaziai asinchroniniai varikliai. Tokie varikliai turi nemažai privalumų lyginant su trifaziais: mažesnės fazinès srovès, mažesni nuostoliai ir srovių harmonikos, galimybè toliau dirbti nutrūkus vienai ar daugiau fazių. Vis daugiau dėmesio skiriama tokių variklių valdymo ir poavarinio režimo padarinių kompensavimo metodams.

Daugiafazių pavarų naudojimą labiausiai stabdo daugiafazio pramoninio elektros tinklo trūkumas. Todèl jos naudojamos tik lokaliose sistemose, kur trifazè tinklo įtampa galios keitikliais verčiama ị reikiamą daugiafazę.

Darbe tirtas šešiafazès asinchroninès pavaros tiesioginio momento ir srauto valdymas naudojant neraiškiosios logikos reguliatorių. Taip pat poavarinio režimo padarinių kompensavimas taikant skaliarinị valdymą ir neraiškiosios logikos kompensatorių.

\section{Darbo aktualumas}

Dèl didesnio patikimumo daugiafaziai varikliai vis dažniau taikomi karinèje ir kosmoso pramonèse, branduolinejje energetikoje ir taip toliau. Šiuo metu didejjant 
elektrinių ir hibridinių automobilių paklausai, šie varikliai vis dažniau pasirenkami dèl savo patikimumo ir galimybès dirbti poavariniu režimu. Tokios pavaroms yra svarbus greičio ir sukimo momento valdymas, todèl jų darbo režimų tyrimai yra labai aktualūs.

Poavarinio režimo pasekmės yra srovių sistemos iškraipymai lyginant su normaliuoju režimu, pakitęs magnetinis laukas ir kritusi pavaros galia. Šioms pasekmėms kompensuoti reikalingas tikslus jų įvertinimas. Mokslinėje literatūroje pastebima, kad dažniausiai apsiribojama tiesioginiu statoriaus srovių matavimu, o sukamasis magnetinis srautas yra išskaičiuojamas. Magnetinių srautų tyrimai yra aktualūs vystant naujus poavarinio režimo padarinių kompensavimo metodus.

\section{Tyrimu objektas}

Darbo tyrimų objektas - šešiafazių asinchroninių elektros pavarų valdymo metodai, skirti normaliajam ir poavariniam režimui.

\section{Darbo tikslas}

Darbo pagrindinis tikslas - sukurti šešiafazių asinchroninių pavarų valdymo būdus, naudojančius neraiškiosios logikos reguliatorius bei gebančius pagerinti statoriaus srovių ir magnetinio srauto kokybinius rodiklius.

\section{Darbo uždaviniai}

Darbo tikslui pasiekti darbe reikia spręsti šiuos uždavinius:

1. Sukurti neraiškiosios logikos reguliatorių vektoriniam tiesioginio momento valdymo būdui, kuris pagerintų daugiafazės pavaros dinamines charakteristikas.

2. Sukurti paieškos metodą, leidžiantị rasti statoriaus ịtampų fazinius kampus, kuriais kompensuojami poavarinio režimo padariniai.

3. Sukurti reguliatorių, kompensuojantị poavarinio režimo metu pasireiškiančius viršsrovius ir statoriaus srovių atstojamojo vektoriaus elipsinę trajektoriją. 


\section{Tyrimų metodika}

Darbe šešiafazių variklių ir pavarų tyrimui taikomas matematinis modeliavimas daugiafazių variklių ir pavarų tyrimui. Modeliavimas atliekamas Matlab Simulink programiniu paketu. Atlikti eksperimentiniai šešiafazès pavaros normaliojo ir poavarinio režimų pereinamujų vyksmų tyrimai. Eksperimentiniai tyrimai atliekami naudojant tyrimų stendą, kurị sudaro šešių fazių dažnio keitiklio maketas, asinchroninis šešių fazių variklis, mechaninè apkrova - elektros generatorius, sukimosi greičio bei sukimo momento jutiklis, srovès matavimo jutikliai, magnetinio srauto tankio jutikliai, duomenų rinkimo sistema.

Eksperimentiniai tyrimai atlikti Vilniaus Gedimino technikos universiteto Elektronikos fakulteto Automatikos katedroje (dabar Elektros inžinerijos katedra). Buvo naudota Valstybinio mokslinių tyrimų instituto Fizinių ir technologijos mokslų centro matavimo duomenų rinkimo įranga.

\section{Darbo mokslinis naujumas}

Rengiant disertaciją buvo gauti šie Elektros ir elektronikos inžinerijos mokslui nauji rezultatai:

1. Sukurtas naujas neraiškiosios logikos reguliatorius skirtas tiesioginio momento valdymo metodui šešiafazių asinchroninių pavarų valdymui normaliuoju režimu.

2. Sukurtas naujas statoriaus įtampų fazinių kampų paieškos metodas, skirtas skaliarinio valdymo daugiafazių pavarų poavarinio režimo statoriaus viršsrovių ir suminio srovių vektoriaus trajektorijos kompensavimui.

3. Sukurtas neraiškiosios logikos reguliatorius, kompensuojantis poavarinio režimo metu pasireiškiančius viršsrovius ir statoriaus srovių atstojamojo vektoriaus elipsinę trajektoriją keičiant statoriaus maitinimo įtampų fazinius kampus.

\section{Darbo rezultatų praktinė reikšmė}

Remiantis disertacijos rezultatais gali būti projektuojamos ir tiriamos daugiafazès asinchroninès pavaros. Sukurti imitaciniai modeliai tinka daugiafazių pavarų tyrimui realiuoju laiku. 
Sukurti daugiafazių asinchroninių pavarų imitaciniai modeliai leidžia toliau vykdyti daugiafazių variklių valdymo metodų tobulinimą ir tyrimus.

Sukurtas šešiafazès asinchroninės pavaros eksperimentinių tyrimų stendas bus naudojamas tolimesniems šešiafazių asinchroninių pavarų tyrimams.

\section{Ginamieji teiginiai}

1. Sukurtas neraiškiosios logikos reguliatorius tiesioginio momento valdymo būdui sumažina elektromagnetinio momento pulsacijas ne mažiau kaip 8 \%, o statoriaus magnetinio srauto ne mažiau kaip 26 \% lyginant su tipiniu tiesioginio momento valdymo būdu.

2. Sukurtas paieškos metodas, kurị sudaro tikslo funkcija, vektorinėmis diagramomis pagrịstos iteracijos ir paieškos algoritmas, leidžia rasti statoriaus įtampų fazinius kampus, sumažinančius poavarinio režimo viršsrovius ir statoriaus srovių atstojamojo vektoriaus trajektorijos elipsiškumą.

3. Sukurtas neraiškiosios logikos reguliatorius leidžia kompensuoti poavarinio režimo metu pasireiškiančius viršsrovius ir statoriaus srovių atstojamojo vektoriaus elipsinę trajektoriją atsižvelgiant ị keturis valdymo parametrus.

\section{Darbo rezultatų aprobavimas}

Disertacijos tema yra atspausdinti 4 moksliniai straipsniai: vienas - mokslo žurnale, ịtrauktame ị Clarivate Analytics Web of Science duomenų bazę (Lisauskas et al. 2013); vienas - Clarivate Analytics Web of Science duomenų bazès Proceedings leidiniuose (Rinkevičienè et al. 2017); du - mokslo žurnaluose, cituojamuose kitose duomenų bazėse (Uznys 2015; Pitrènas et al. 2017).

Disertacijoje atliktų tyrimų rezultatai buvo paskelbti devyniose mokslinėse konferencijose:

- Lisauskas, S.; Udris, D.; Uznys, D. 2013. Direct Torque Control of Induction Drive Using Fuzzy Controller. Septynioliktoji tarptautinè konferencija „Elektronika 2013“. Palanga, 2013 m. birželio 17-19 d.

- Uznys, D. 2014. Šešiafazio variklio modeliavimas. Septynioliktoji Lietuvos jaunujų mokslininkų konferencija „Mokslas - Lietuvos ateitis“. Vilnius, $2014 \mathrm{~m}$. kovo $21 \mathrm{~d}$. 
- Uznys, D. 2015. Šešiafazio variklio valdymas. Aštuonioliktoji Lietuvos jaunujų mokslininkų konferencija „Mokslas - Lietuvos ateitis“. Vilnius, $2015 \mathrm{~m}$. kovo $20 \mathrm{~d}$.

- Uznys, D. 2016. Šešiafazio variklio gedimo režimo modeliavimas. Devynioliktoji Lietuvos jaunujų mokslininkų konferencija „Mokslas - Lietuvos ateitis“. Vilnius, $2016 \mathrm{~m}$. kovo $18 \mathrm{~d}$.

- Pitrėnas, A.; Uznys, D. 2016. Daugiafazio variklio apskritiminės srovės trajektorijos kūrimas asimetriniu darbo režimu. Trečioji atvira elektros, elektronikos ir informatikos mokslų konferencija „eStream“. Vilnius, $2016 \mathrm{~m}$. balandžio $19 \mathrm{~d}$.

- Uznys, D. 2017. Modeling of Six-Phase Induction Drives in Post-Fault Conditions. International Conference "Electrical, Electronic and Information Sciences”. Vilnius, $2017 \mathrm{~m}$. balandžio $27 \mathrm{~d}$.

- Rinkevičienè, R.; Savickienė, Z.; Uznys, D.; Pitrènas, A.; Šlepikas, A. 2017. Scalar Control of Six-Phase Induction Motor. International Conference “Electrical, Electronic and Information Sciences”. Vilnius, 2017 m. balandžio $27 \mathrm{~d}$.

- Uznys, D.; Pitrénas, A.; Beištaras, D.; Lisauskas, S. 2017. Direct Measurement of Six-Phase Induction Drive Magnetic Flux in the Air Gap. 13th International Conference "Mechatronic Systems and Materials". Vilnius, 2017 m. liepos 3-5 d.

- Rinkevičienè, R.; Savickienè, Z.; Lisauskas, S.; Petrovas, A.; Uznys, D.; Pitrènas, A.; Šlepikas, A. 2017. Fuzzy Controllers in Rotor Flux Orientation Control System of Six-Phase Induction Motor. 13th International Conference "Mechatronic Systems and Materials". Vilnius, 2017 m. liepos 3-5 d.

\section{Disertacijos struktūra}

Disertaciją sudaro įvadas, trys skyriai ir bendrosios išvados. Taip pat yra trys priedai.

Darbo apimtis yra 98 puslapiai, neskaitant priedų, tekste panaudotos 48 numeruotos formulès, 51 paveikslas ir 9 lentelès. Rašant disertaciją buvo panaudoti 94 literatūros šaltiniai. 



\section{1}

\section{Daugiafazių elektros pavaru apžvalga ir analizè}

Skyriuje apžvelgiama daugiafazių variklių taikymo atvejai, jų konstrukcija, veikimo ir valdymo principai. Išnagrinèti tokių variklių matematiniai ir kompiuteriniai modeliai, asinchroninių variklių koordinačiu transformavimo sistemos. Taip pat aptarti daugiafazių asinchroninių variklių greičio ir momento reguliavimo būdai. Skyriaus pabaigoje pateikiamos pirmojo skyriaus išvados ir tikslinami darbo uždaviniai.

Skyriaus tematika paskelbtas vienas straipsnis (Uznys 2015).

\subsection{Daugiafazių elektros pavarų taikymo sritys ir konstrukcijos}

Šiuolaikinès mechatroninès sistemos renka jutiklių informaciją, ją apdoroja ir pagal nustatytus valdymo algoritmus generuoja jëgas bei judesius. Judesius tokiose sistemose generuoja pneumatiniai, hidrauliniai arba elektriniai vykdikliai, kurie yra jungiamoji valdiklių ir valdomųjų mašinų grandis ir kuria sukamajį ar slenkamajji judesį. Dèl išplètoto elektros energijos perdavimo tinklų infrastruktūros daž- 
niausiai naudojami vykdikliai yra elektros varikliai, kurie gali dirbti trumpalaikiais ar ilgalaikiais režimais, būti dažnai stabdomi ar keisti greitị ir momentą pagal užduotą dėsnị. Dažniausiai vykdikliai parenkami pagal užduotą technologinị procesą, reikalingą galią, judesio tipą, darbo režimą, sukimosi greičio reguliavimo diapazoną, patikimumą ir kitus parametrus.

Tradiciškai dèl galimybės tiksliai valdyti greitị, tiesinės mechaninės charakteristikos reguliuojamosiose pavarose buvo naudojami kolektoriniai nuolatinès srovès elektros varikliai, tačiau nuo 1990 m. vis dažniau imta naudoti asinchroninius kintamosios srovès variklius (Bose 2006). Mechatroninès sistemos variklio kaina ir patikimumas yra svarbūs rodikliai, todèl kolektoriniai nuolatinès srovès varikliai vis rečiau naudojami dèl jų trūkumų (šepečių nusidèvẻjimas, kibirkščiavimas, akustinis triukšmas). Juos pakeitė elektroniškai komutuojami nuolatinès srovès, kintamosios srovès sinchroniniai varikliai su nuolatiniais magnetais rotoriuje, asinchroniniai elektros varikliai (Leonhard 2001). Jų patikimumas padidèja, nes juose nèra kolektoriaus ir vienintelè besidèvinti detalè yra guoliai.

Pramonejje paplitęs trifazis elektros tinklas lemia tai, kad labiausiai paplitę varikliai yra trifaziai kintamosios srovės asinchroniniai varikliai. Šio tipo varikliai pasižymi nesudètinga eksploatacija ir patikimumu, lyginant su nuolatinès srovès varikliais. Dažnio keitiklių tobulèjimas leido kintamosios srovės pavaroms ịsitvirtinti pramonėje ir autonominėse sistemose, tačiau anksčiau minètose srityse (ypač autonominèse sistemose, kur fazių skaičiaus neriboja pramoninis tinklas) tipinės konstrukcijos trifazès mašinos ne visada yra geriausias sprendimas, užtikrinantis geriausius rezultatus. Iprasta, kad trifazę srovių sistemą naudojantys daugiafaziai varikliai yra vadinami trifaziais, o daugiafaziais laikomi varikliai, kurių fazių skaičius didesnis už tris. Šioje disertacijoje bus laikomasi tokios pačios sampratos. Daugiafazès mašinos turi keletą privalumų lyginant su trifazėmis mašinomis. Pagrindiniai privalumai yra (Golubev, Ignatenko 2000; Levi et al. 2007; Levi et al. 2008; Levi 2016; Jacobina et al. 2004; Kianinezhad et al. 2008a; Duran, Barrero 2015; Duran et al. 2016; Batista et al. 2013; Gonzalez-Prieto et al. 2016):

1. Bendra sistemos galia paskirstoma daugiau nei trims fazèms, dèl to sumažèja vienos fazès apvijos srovè, komutuojama puslaidininkiniais galios įtaisais.

2. Daugiafaziuose varikliuose gaunami mažesni statoriaus nuostoliai, mažesnès rotoriaus srovių harmonikos ir sukimo momento pulsacijos. Šešiafaziai asinchroniniai varikliai turi 6,7 \% mažesnius elektrinius nuostolius, lyginant juos su trifaziais varikliais, kuriuose suklotos ekvivalentiškos, tokio paties žingsnio fazinès apvijos.

3. Daugiafazès mašinos yra atsparesnès gedimams ir gali veikti poavariniu režimu, t. y. sugedus vienai ar daugiau statoriaus fazių, o tai gerokai didina ne tik šių variklių bet ir visos sistemos patikimumą. Trifaziam varikliui nemaitinant nors vienos fazès, jis dirba kaip 
vienfazis variklis, jei nėra neutralaus laido, todèl jo galia sumažèja $50 \%$, jis negali pats pasileisti. Daugiafaziam varikliui nemaitinant vienos apvijos, jis gali pasileisti ir jo galia sumažejja minimaliai. Taip pat atjungus tokią fazę galima remontuoti maitinimo šaltinị nestabdant pačios pavaros. Šešiafaziai asinchroniniai varikliai gali būti paleisti ir veikti, jei yra bent trys veikiančios fazès, su sąlyga, kad gedimai atsiranda ne gretimose statoriaus fazèse.

4. Esant bet kokiam kintamos srovės mašinos fazių skaičiui, norint nepriklausomai valdyti jos srautą ir sukimo momentą, reikia keisti dvi nepriklausomai valdomas srovès dedamąsias.

5. Daugiafaziai varikliai taip pat pasižymi mažesniu akustiniu triukšmu, lyginant su trifaziais varikliais.

Daugiafazių mašinų koncepcija atsirado 1920 metais, kai atsirado didelès galios poreikis ir kurios dydį ribojo tuo metu naudojami galios puslaidininkiniai raktai. Tuomet trifazis generatorius būdavo verčiamas į šešiafazị, todèl jų faziné srovė buvo du kartus mažesnè. Šis sprendimas tapo neaktualus, kai padidèjo puslaidininkinių raktų srovès dydis (Kim et al. 2013).

1960 metais pradejjus kurti dažniu valdomas elektros pavaras, vèl buvo susidomèta daugiafazèmis mašinomis. Pagrindinè priežastis buvo didelès momento vibracijos maitinant variklius žemo dažnio ịtampa, kai inverteriai veikè šešių žingsnių principu (angl. six-step). Didesnis fazių skaičius leido tas vibracijas sumažinti, tačiau atsiradus IPM valdymui, toliau daugiafazių pavarų sritis nebuvo vystoma (Kim et al. 2013).

Pirmasis daugiafazis variklis straipsniuose paminètas 1969 metais (Ward, Härer 1969). Tuo metu daugiausiai dėmesio buvo skiriama daugiafazių variklių modeliavimui, projektavimui, dažninio valdymo klausimams (Duran, Barrero 2015; Levi 2016). Tyrimai šioje srityje suintensyvejjo tik dvidešimto amžiaus paskutiniame dešimtmetyje ir pirmame šio amžiaus dešimtmetyje.

Daugiafazès mašinos gali sklandžiai veikti poavariniu režimu, kai yra nutrūkęs maitinimas vienai ar kelioms statoriaus apvijoms. Maitinimas gali nutrūkti dèl IGBT tranzistorių, energijos perdavimo kabelių gedimų ar suveikus apsaugos automatikai ir atjungus fazès maitinimą (Munim et al. 2016).

Galimybè dirbti poavariniu režimu iš karto sudomino mokslininkus, tačiau daugiafazių pavarų kūrimas ir taikymas pradžioje apsiribojo keleto trifazių variklio apvijų, maitinamų iš trifazio tinklo, tyrimais (Gemesa 2016; Ditmanson et al. 2014; Cao et al. 2012). Nuo 1990 metų, atsižvelgus ị daugiafazių variklių privalumus: galimybes dirbti poavariniu režimu, naudoti mažesnès galios elektronikos įtaisus, jie pradèti taikyti laivuose, dèl to ypatingai suaktyvėjo jų tyrimai (Duran et al. 2016; Levi 2016; Kim et al. 2013).

Šis tyrimų suintensyvejjimas ir naujų publikacijų atsiradimas paskatino ir teminio žurnalo IEEE Transactions on Industrial Electronics „Special Section on 
Multiphase Machines and Drives“ numerio publikavimą 2008 metų gegužès mènesį.

Daugiausiai dėmesio mokslinėse publikacijose skiriama: maitinimo šaltinių skirtų daugiafazèms mašinoms ir jų valdymo sistemoms (galios elektronikos elementų, dažnio keitiklių, inverterių), tokių mašinų konstrukcijos, modeliavimo ir valdymo metodų, poavarinio režimo tyrimams.

Daugiafazès mašinos priklausomai nuo statoriaus apvijų tipo gali būti maitinamos iš skirtingų dažnio keitiklių. Labiausiai paplitusios šios daugiafazių elektros pavarų (mašina ir įtampos inverteris) konfigūracijos (Bojoi et al. 2016; Cheng et al. 2009; Oleschuk, Ermuratskii 2014; Kominami, Fujimoto 2004; Jones et al. 2013):

1. Daugiafazès mašinos su viena neutrale (1.1 pav.).

2. Daug nepriklausomų vienfazių vienetų (1.2 pav.).

3. Daug nepriklausomų trifazių vienetų (1.3 pav.).

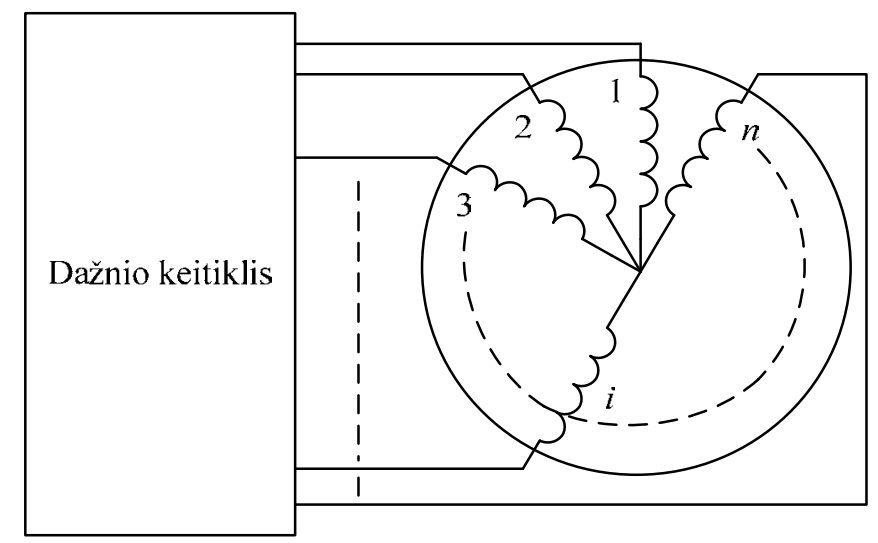

1.1 pav. Daugiafazių mašinų topologija su viena neutrale Fig. 1.1. Topology of multi-phase machine with single neutral

Paveiksle 1.1 pateiktoje topologijoje yra tik vienas dažnio keitiklis, kuris maitina visas $n$-fazio variklio apvijas (sunumeruotas skaičiais $1,2,3, i$ ir $n$, kur $i$ kitų fazių numeriai). Šis keitiklis turi formuoti statoriaus maitinimo įtampas su $n$ fazinių kampų. Apvijų jungimas - žvaigždè.

Paveiksle 1.2 pateiktoje topologijoje naudojami vienfaziai keitikliais. $n$-faziam varikliui reikia $n$ skaičiaus keitiklių, kurie yra izoliuoti vienas nuo kito - jie neturi nei vienos bendros neutralès. Šis variantas yra brangesnis už topologiją pateiktą paveiksle 1.1, nes daugiafaziam keitikliui užtenka dvigubai mažiau pakopų lyginant su bendru pakopų kiekiu būtinų vienfazių keitiklių atveju. 


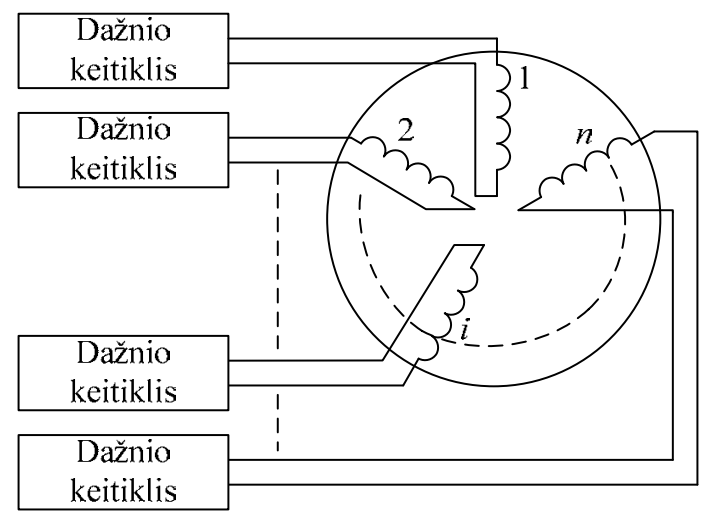

1.2 pav. Daugiafazių mašinų topologija sudaryta iš daugelio nepriklausomų fazių

Fig. 1.2. Multi-phase machine topology with multiple single-phase units

Daugiafazès pavaros maitinamos iš trifazių dažnio keitiklių topologijas pateikta paveiksle 1.3 .

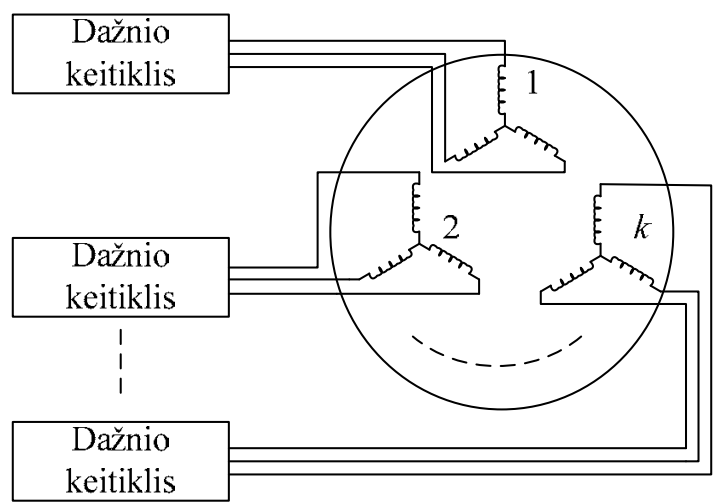

1.3 pav. Daugiafazis variklis sudarytas iš daugelio nepriklausomų trifazių vienetu

Fig. 1.3. Multi-phase machine topology with multiple three-phase units

Variklį, kurio statoriaus fazių skaičius yra kartotinis skaičiaus 3, galima maitinti iš trifazių keitiklių, jei jie turi sinchronizavimo funkciją. Toks variantas yra populiarus, nes trifaziai keitikliai yra gaminami masiškai. Be to, įvairūs gedimai gali būti izoliuoti atjungiant vieną keitiklį, kuris maitina 120 elektrinių laipsnių kampu suklotas apvijas. Taip išlaikomas pavaros srovių sistemos simetriškumas, kuris užtikrina patikimą poavarinio režimo pavaros darbą, jei nėra perkrovų. 
Atsižvelgiant ị statoriaus apvijų padètį ir kampą tarp jų, šešiafaziai asinchroniniai varikliai gali būti trijų rūšių (1.4 pav.):

1. Dvigubo trifazio statoriaus (1.4 pav. a).

2. Asimetriniai (1.4 pav. b).

3. Simetriniai (1.4 pav. c).

a)

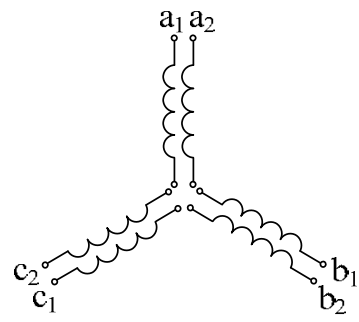

b)

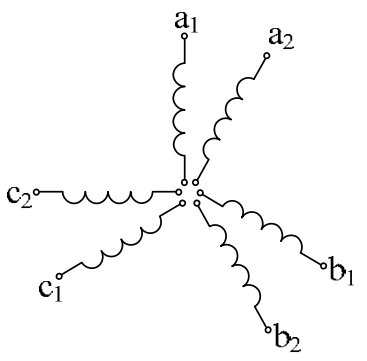

c)

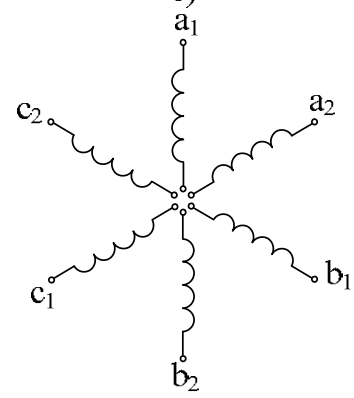

1.4 pav. Šešiafazių asinchroninių variklių apvijų padètis statoriuje: a) dvigubo statoriaus; b) asimetrinio variklio; c) simetrinio variklio

Fig. 1.4. Three mainstream six-phase machines: a) dual three-phase machine; b) asymmetrical six-phase machine; c) symmetrical six-phase machines

Simetriniu atveju laikomas toks statoriaus apvijų klojimas, kai sudaromas erdvinis kampas tarp gretimų fazių yra 60 elektrinių laipsnių (1.4 pav. c). Toks atvejis yra nagrinėjamas dažniausiai (Mansour et al. 2008; Markadeh et al. 2009; Nanoty, Chudasama 2012). Rečiau sutinkami šešiafaziai varikliai su asimetriniu statoriumi. Juose kampai tarp gretimų fazių yra nevienodi (1.4 pav. b) - vienas iš jų 30 elektrinių laipsnių ir kitas 90 elektrinių laipsnių.

Kai šešiafazių variklių rotoriuje suklota šešiafazè apvija, tai kampinis poslinkis tarp gretimų rotoriaus fazių sudaro 60 elektrinių laipsnių. Faziniuose rotoriuose, kuriuose yra suklota trifazė apvija, kampinis poslinkis tarp skirtingų rotoriaus fazių sudaro 120 elektrinių laipsnių.

Iprastai nagrinejjami šešiafaziai varikliai su skirtingomis statorių ir rotorių kombinacijomis. Atsižvelgiant ị literatūroje nurodytus atvejus, galima teigti, kad dažnai nagrinėjami varikliai, kurių statoriuje suklota asimetrinè šešiafazė apvija, o rotoriuje nurodoma trifazė apvija. Nemažas dėmesys skiriamas ir variklių su simetrine šešiafaze apvija statoriuje bei rotoriuje nagrinèjimui.

Šios disertacijos tyrimuose naudojamas simetrinis šešiafazis asinchroninis variklis su narveliniu rotoriumi.

Daugiafazių variklių maitinimas iš įvairių įtampos inverterių plačiai išnagrinètas (Levi 2016) straipsnyje. Jame aprašomi nauji daugiafazių pavarų impulsų 
moduliacijos valdymo metodai, kurie naudojami dviejų ir daugiau lygių įtampos inverteriuose, maitinant žvaigžde sujungtą daugiafazę mašiną. Šie valdymo metodai lyginami tarpusavyje, taip pat lyginama gautu statoriaus ịtampų ir srovių kokybė, tiriant harmonikų iškraipymus. Nagrinejjama kitos dažnio keitiklio topologijos ir valdymo būdai naudojant matricinius ịtampos keitiklius (angl. matrix converter). Taip pat straipsnyje nagrinejjamas daugiafazès pavaros panaudojimas elektromobiliuose. Daugelyje šiuolaikinių elektromobilių naudojami du inverteriai, vienas iš jų naudojamas elektros variklio valdymui ir regeneruotos energijos gražinimui i bateriją, kitas krovimo metu, kai elektromobilis įkraunamas iš elektros tinklo. Straipsnyje siūlomas būdas naudoti tik vieną inverterị abiem operacijoms atlikti. Toks jungimas leidžia naudoti daugiafazị variklị kaip filtrą, nes fazèmis tekančios srovès nesukuria besisukančio magnetinio lauko, tuo pačiu ir sukimo momento. Tokių pavarų panaudojimas leistų atsisakyti papildomo krovimo inverterio ir sumažintų bendrą sistemos masę.

Daugiafazèse mašinose srovių harmoninè sudètis yra geresnè nei trifazèse, tačiau šių rodiklių gerinimas yra aktualus. (Karttunen et al. 2015) straipsnyje pateikiamas dvigubos trifazès (asimetrinès šešiafazės) pavaros srovès valdymo metodas, kuris ženkliai sumažina statoriaus srovių nepageidaujamas harmonikas. Metodas, paremtas trikdžių stebikliu (angl. disturbance observer), panaikina daugiau nei 99 \% nepageidaujamų harmonikų normaliojo darbo režimo metu. Lietuvoje vystyta statoriaus srovių harmonikų tyrimai, kai taikomi erdvinio vektoriaus moduliavimo metodai (Baškys et al. 2011; Lipinskis 2014; Lipinskis 2013; Lipinskis et al. 2014; Lipinskis et al. 2013; Lipinskis, Bleizgys 2016; Lipinskis, Zlosnikas 2015).

Daugiafazès mašinos tobulinamos ne tik vystant valdymo būdus, bet ir konstrukcijas. Trifazių variklių kontekste, ši tema yra labai gerai išnagrinèta, tačiau esant daugiau fazių, pavyzdžiui, esant penkioms fazèms (Abdel-Khalik et al. 2016; Barrero, Duran 2016; Duran, Barrero 2015) mokslinė bazè yra vystoma. Taip pat, daugiafazių mašinų apvijų projektavimo tema vykdyti moksliniai tyrimai ir Lietuvoje (Bukšnaitis 2015; Bukšnaitis 2013; Bukšnaitis 2012; Kundrotas 2013; Kundrotas et al. 2014).

Pavaros kokybės vertinimui dažnai pasitelkiama magnetovaros ar magnetinio srauto analizè (Patel et al. 2015; Zhang et al. 2016). Magnetiniai srautai nèra matuojami tiesiogiai, bet išskaičiuojami iš statoriaus srovès ir elektrovaros. Pavyzdžiui, nesinusinès maitinimo įtampos įtakos tyrimams penkių ir devynių fazių varikliuose (Kong et al. 2016).

Normaliojo režimo atveju tyrimams galima apsiriboti dinaminių procesų modeliavimu neatliekant eksperimentų (Zhang et al. 2016). Šie matematiniai modeliai yra žinomi, tačiau sėkmingai vystomi ir toliau (Shao et al. 2015; Kundrotas 2014; Kundrotas et al. 2011; Pitrėnas, Uznys 2016; Pitrėnas 2014). 
Daugiafazès pavaros yra patikimesnès už trifazes, tačiau jų valdymas yra sudètingesnis. Specialūs valdymo būdai gali užtikrinti nenutrūkstamą darbą besikeičiant darbo sąlygoms: iš normaliojo darbo režimo, ị gedimą ir ị poavarinị režimą (Nguyen et al. 2015; Guzman et al. 2015; Duran et al. 2016). Tačiau šiems valdymams poavarinio režimo metu reikalauja daug tikslių grįžtamųjų ryšių.

Galima teigti, kad daugiafazių variklių pranašumai prieš įprastus trifazius variklius ịtakojo jų taikymą įvairiose pramonès šakose: jūrų transporte, laivuose (Taheri et al. 2012; Santos et al. 2011; Moghadasian et al. 2010; Nabi et al. 2011), elektrinėse arba elektrinėse-hibridinėse transporto priemonèse, orlaiviuose, lokomotyvuose (Alnajjar et al. 2015; Cavagnino et al. 2015; Baltatanu et al. 2013; Vukosavic et al. 2005; Abjadi et al. 2010; Ahmed 2012; Oleschuk, Griva 2009; Oleschuk et al. 2007; Levi et al. 2006; Levi 2008), vandens aparatuose, erdvèlaiviuose, robotams valdyti bei didelès galios ịrenginiuose (Bojoi et al. 2016; Goyal, Aware 2012; Santos et al. 2010).

Pramonèje naudojamas trifazis tinklas ir daugiafazio variklio maitinimui reikalingos papildomos priemonès, kurios transformuotų trifazị tinklą ị reikiamo fazių skaičiaus daugiafazi elektros tinklą, ir tai yra pagrindinė priežastis, kodėl spartesnis šio tipo variklių taikymas plačiojoje pramonèje yra ribotas. Specialus transformatorius, kuris transformuoja trifazi elektros tinklą ị šešiafazị, gali būti naudojamas maitinti šešiafaziams asinchroniniams varikliams, taip pat šią funkciją atlikti gali ir šešiafazis dažnio keitiklis, kuris transformuoja pramoninị trifazị kintamosios srovès tinklą i šešiafazị, kintamo dažnio ir amplitudès tinklą. Kai daugiafazėse pavarose daugiafazis variklis maitinamas iš dažnio keitiklio, galima reguliuoti daugiafazio variklio sukimosi greitị, tačiau jei maitinama iš specialaus transformatoriaus, tai variklio sukimosi greičio keisti neįmanoma. Tiek specializuotas transformatorius, tiek daugiafazis dažnio keitiklis yra papildomas daugiafazès pavaros elementas, dèl kurio kyla visa pavaros kaina, tačiau papildomas pavaros elementas, nors ir kelia sistemos kainą, yra vertinamas kaip atsiperkanti investicija dèl didesnio pavaros patikimumo.

Daugiafaziai varikliai populiarūs didelès galios ir traukos ịrenginiuose, ịprastuose bei povandeniniuose laivuose, lokomotyvuose. Daugiafaziuose varikliuose ši galia visoms jị sudarančioms fazinėms apvijoms paskirstoma po lygiai, todèl šių variklių fazinès srovès bus mažesnès, lyginant su tokios pačios galios trifaziais varikliais. Todèl daugiafazius variklius maitinančiuose dažnio keitikliuose galima naudoti mažesnès galios puslaidininkinius raktus, kurių kaina yra mažesnè.

Daugiafaziai varikliai, dèl jų gebẻjimo dirbti dingus vienai ar daugiau iš statoriaus fazių, gali užtikrinti šių ịrenginių nepertraukiamą darbą, todèl daugiafazis elektros tinklas gali būti kuriamas pvz., branduoliniuose objektuose, avariniuose ịrenginiuose, kai ypač svarbus ịrenginių patikimumas. Daugiafazis tinklas gali būti gaunamas naudojant pageidaujamo skaičiaus fazių generatorių, fazių skaičiaus keitimo transformatorių arba inverterị. 
Galimybė daugiafazei elektros pavarai funkcionuoti esant gedimui lemia jų naudojimą ir kosmoso pramonejje. Šiuo atveju ypatingą reikšmę turi ir mažesni remonto kaštai, kurie kosmoso pramoneje yra daug didesni nei įprastai.

Dažniausiai gedimai izoliuojami atjungiant vieną ar daugiau statoriaus fazių. Tokiu atveju gaunami srovių sistemos iškraipymai tokie kaip 1.5 paveiksle.

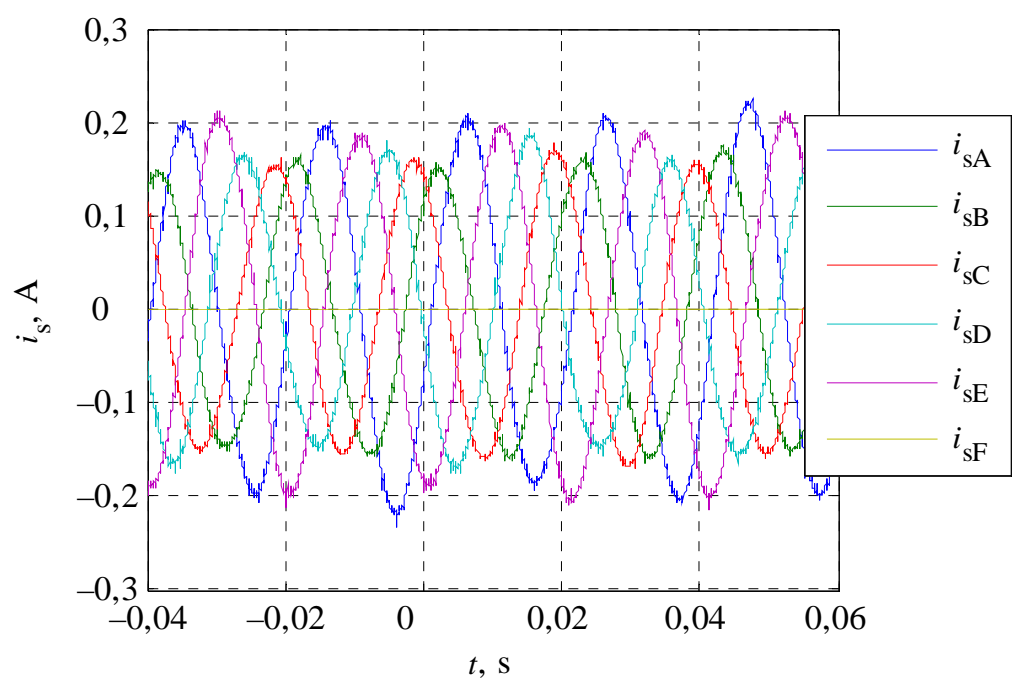

1.5 pav. Statoriaus fazinès srovès, kai atjungta $F$ fazès apvija (Pitrènas 2017)

Fig. 1.5. Stator phase currents when winding of $F$ phase is disconnected (Pitrenas 2017)

Siekiant kompensuoti poavarinio režimo metu išaugusias statoriaus fazines sroves (1.5 pav.) ir atstojamojo srovès vektoriaus trajektoriją, buvo pasiūlytas kompensavimo metodas (Pitrènas et al. 2017; Pitrénas 2017). Jo metu yra keičiami dažnio keitiklio formuojamų ịtampų faziniai kampai, nekeičiant formuojamų ịtampų amplitudžių. Taikant šị metodą simetriné šešiafazė asinchroninè dažninè pavara maitinama iš penkiafazio asimetrinio maitinimo tinklo, kurio įtampų faziniai kampai gali būti keičiami.

Poavarinis režimas imituojamas atjungiant vieną šešiafazès asinchroninès dažninès pavaros fazè. Pavarai veikiant šiuo režimu kai kurių statoriaus fazinių srovių amplitudès išauga iki 40 \% (1.5 pav.), o statoriaus srovių atstojamojo vektoriaus trajektorija tampa elipsine (1.6 pav.). Normaliojo režimo atveju visų srovių amplitudès lygios, o trajektorija - apskritiminè. 


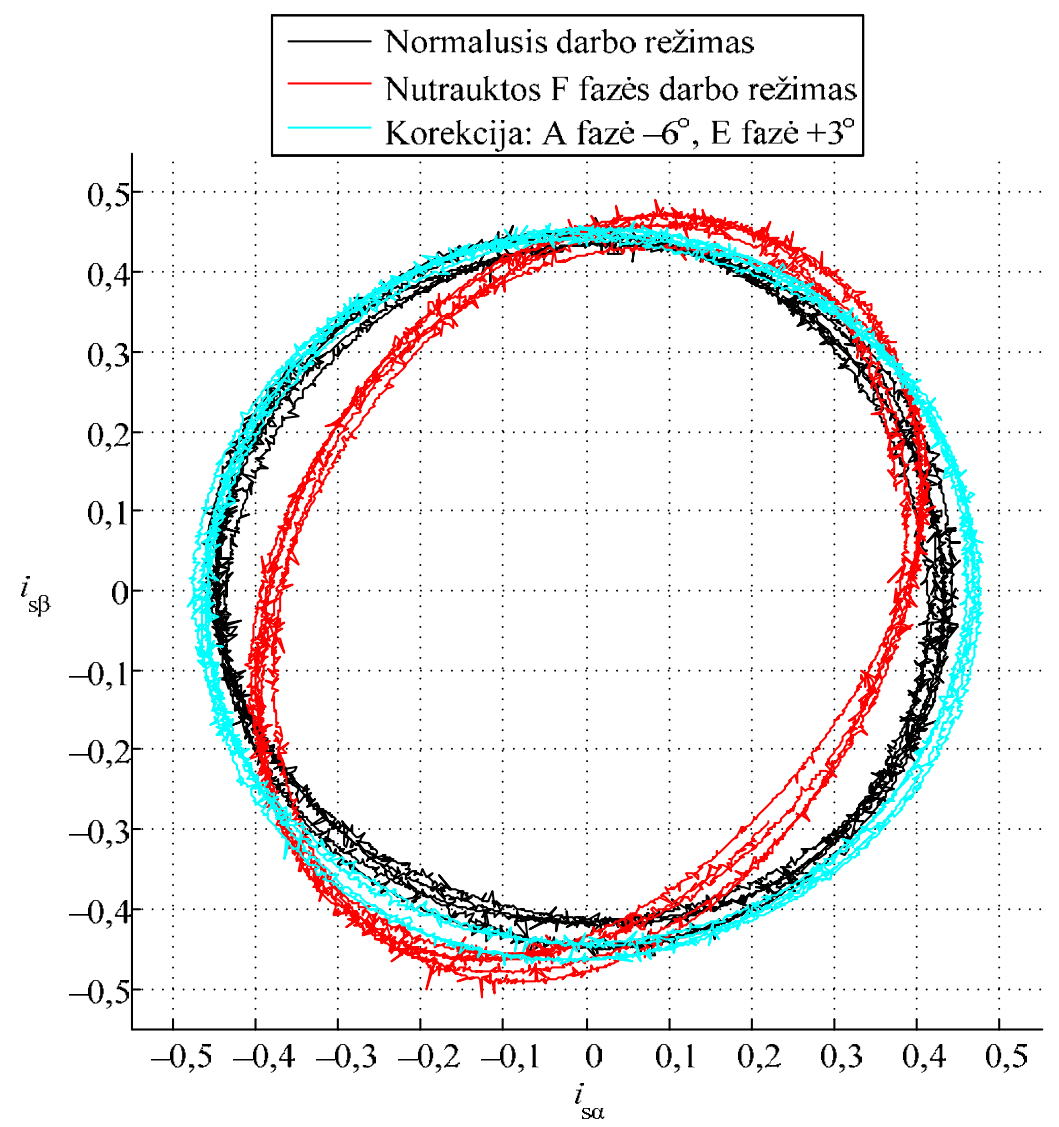

1.6 pav. Statoriaus fazinių srovių atstojamojo vektoriaus trajektorija nejudamoje koordinačių sistemoje, kai pavara dirba normaliuoju ir vienos fazès kompensuoto poavarinio režimo sąlygomis (Pitrènas 2017)

Fig. 1.6. Resultant vector trajectory of stator phase currents in stationary reference frame when the drive is working in normal operating and compensated post-fault conditions (Pitrènas 2017)

Taikant pasiūlytą poavarinio režimo statoriaus fazinių srovių ir suminio srovès vektoriaus trajektorijos kompensavimo metodą (Pitrènas et al. 2017), šešiafazė asinchroninè dažninė pavara maitinta iš penkiafazio maitinimo tinklo, kurio itampų faziniai kampai yra $\left[-6^{\circ}, 60^{\circ}, 120^{\circ}, 180^{\circ}, 243^{\circ}\right.$, - ]. Šiuo atveju gautos fazinės srovės, kurių amplitudžių dispersija 10 kartų mažesnè lyginant su nekompensuotu režimu, t. y. dispersija artima normaliojo režimo srovių dispersijai (1.7 pav.). Taip pat statoriaus atstojamojo vektoriaus trajektorija atstatyta ị apskritiminę (1.6 pav.). 


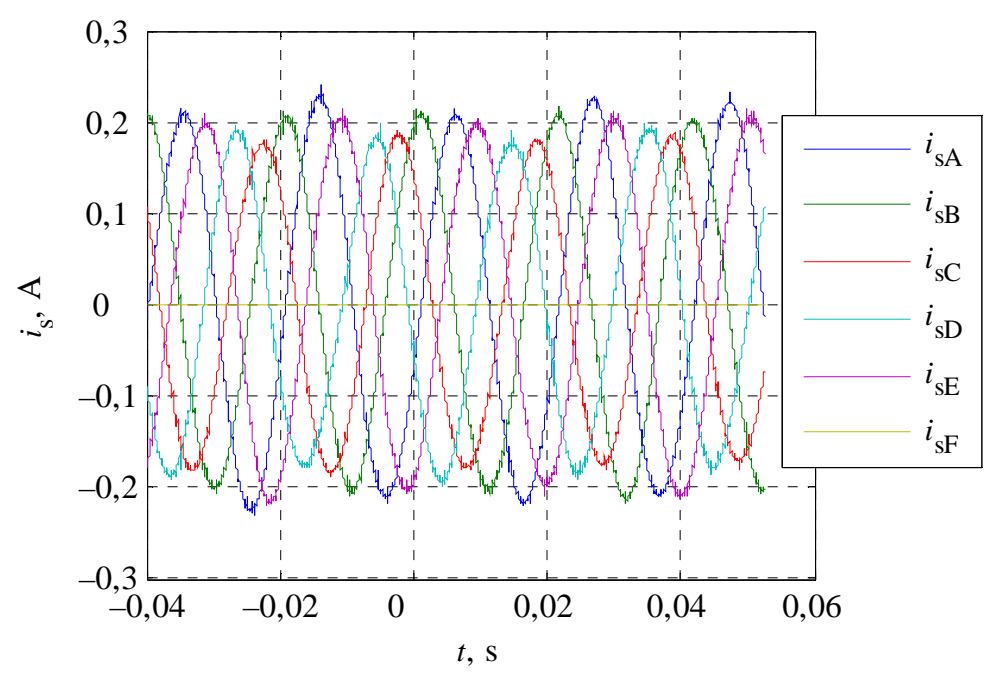

1.7 pav. Akimirkinės statoriaus srovès, kai pavara dirba vienos fazės kompensuoto poavarinio režimo sąlygomis (Pitrènas 2017)

Fig. 1.7. Instantaneous stator phase currents when the drive is working in compensated post-fault condition (Pitrènas 2017)

Kompensavimo metodui iškeltas pirminis tikslas - apskritiminès trajektorijos atstatymas - turi daug sprendinių. Reikiamą trajektoriją galima užtikrinti didele statoriaus maitinimo ịtampų fazinių kampų rinkinių aibe. Iškẻlus papildomą tikslą - sumažinti statoriaus fazinių srovių dispersiją - sprendinių skaičius sumažèja.

Eksperimentiškai ịrodyta, kad apskritiminę statoriaus srovių atstojamojo vektoriaus trajektoriją galima atkurti pasiūlytu skaliariniu poavarinio režimo kompensavimo metodu, veikiančiu be grižžtamojo ryšio. Taip pat įrodyta, kad iširtos šešiafazès asinchroninės dažninès pavaros, veikiančios vienos nutrūkusios fazės poavariniu režimu, statoriaus fazinès srovès išauga - didžiausia efektinė vertė siekia $40 \%$, o atkūrus apskritiminę srovès vektoriaus trajektoriją sumažèja ir siekia $31 \%$ (1.7 pav.).

Disertacijoje ir susijusioje publikacijoje pateikiami tik tuščiosios veikos eksperimentiniai tyrimai ir nèra nagrinejjama, ar vienas sprendinys yra tinkamas visiems to pačio režimo darbo taškams. Taip pat nèra nurodyta, kaip rasti maitinimo įtampų fazinių kampų postūmiai, t. y. trūksta paieškos metodo. Siekiant ištirti metodo tinkamumą darbui ịvairiuose darbo taškuose, reikia suformuluoti statoriaus maitinimo įtampų fazinių kampų tikslo funkciją. Nagrinèjamo valdymo būdo tyrimuose apsiribota rankiniu valdymo parametrų įvedimo būdu, o ne automatiškai 
keičiamais įtampų faziniais kampais, kas yra būtina nenutrūkstamam pavaros darbui.

\subsection{Daugiafazio variklio dinaminiai modeliai}

Šiame poskyryje pateikiami du tipiniai daugiafazio asinchroninio elektros variklio matematiniai modeliai. Jie reikalingi elektros pavarų valdymo būdų vystymui, nes igalina mažomis išlaidomis išbandyti ịvairius atvirų ir uždarų valdymo sistemų principus. Taip pat, modeliuojant parinkti reguliatorių parametrai yra labai svarbūs, nes eksperimentinis tinkamų parametrų radimas gali būti sunkiai ịgyvendinamas.

Tipiniai variklio modeliai yra sudaryti pagal ekvivalentinę schemą kaip ir trifazio variklio modelio atveju (Bose 2002). Toks modelis yra idealizuotas ir laikoma, kad visų fazių techniniai parametrai yra vienodi: statoriaus apvijų aktyviosios varžos yra lygios, abipusiai rotoriaus fazių induktyvumai yra lygūs ir t. t. Tai yra priimtina, kol toks matematinis modelis yra naudojamas pavaros tyrimams normaliojo režimo metu.

Esminis daugiafazio asinchroninio variklio skirtumas lyginant su trifaziu varikliu yra statoriaus fazių skaičius.

Šešiafazio variklio statoriaus maitinimo fazinių ịtampų balanso lygtys yra šios:

$$
\left\{\begin{array}{l}
u_{\mathrm{A}}=\frac{\mathrm{d} \Psi_{\mathrm{A}}}{\mathrm{d} t}+R_{\mathrm{A}} i_{\mathrm{A}}, \\
u_{\mathrm{B}}=\frac{\mathrm{d} \Psi_{\mathrm{B}}}{\mathrm{d} t}+R_{\mathrm{B}} i_{\mathrm{B}}, \\
u_{\mathrm{C}}=\frac{\mathrm{d} \Psi_{\mathrm{C}}}{\mathrm{d} t}+R_{\mathrm{C}} i_{\mathrm{C}}, \\
u_{\mathrm{D}}=\frac{\mathrm{d} \Psi_{\mathrm{D}}}{\mathrm{d} t}+R_{\mathrm{D}} i_{\mathrm{D}}, \\
u_{\mathrm{E}}=\frac{\mathrm{d} \Psi_{\mathrm{E}}}{\mathrm{d} t}+R_{\mathrm{E}} i_{\mathrm{E}}, \\
u_{\mathrm{F}}=\frac{\mathrm{d} \Psi_{\mathrm{F}}}{\mathrm{d} t}+R_{\mathrm{F}} i_{\mathrm{F}} .
\end{array}\right.
$$

Disertacijoje pateiktiems moksliniams tyrimams reikalingas variklio su narveliniu rotoriumi modelis, todèl lygtys yra sukonkretintos. Laikoma, kad toks rotorius yra ekvivalentus trifaziam faziniam rotoriui. 
Daugiafazio variklio rotoriaus trijų menamų fazinių ịtampų balanso lygtys yra šios:

$$
\left\{\begin{array}{l}
u_{\mathrm{a}}=\frac{\mathrm{d} \Psi_{\mathrm{a}}}{\mathrm{d} t}+R_{\mathrm{a}} i_{\mathrm{a}}, \\
u_{\mathrm{b}}=\frac{\mathrm{d} \Psi_{\mathrm{b}}}{\mathrm{d} t}+R_{\mathrm{b}} i_{\mathrm{b}}, \\
u_{\mathrm{c}}=\frac{\mathrm{d} \Psi_{\mathrm{c}}}{\mathrm{d} t}+R_{\mathrm{c}} i_{\mathrm{c}} .
\end{array}\right.
$$

Daugiafazis modelis gali būti supaprastintas kelis vektorius transformavus i du statmenus vektorius, t. y. skaičiuojant projekciją i dvimatę koordinačių sistemą. Tai atliekama pasitelkiant Klarko transformaciją (Microsemi 2013).

Prieš ir po transformacijos sistemos kintamųju skaičius turi likti nepakitęs (Abjadi et al. 2010; Renukadevi, Rajambal 2012). Šešiafazis simetrinis asinchroninis variklis, kurio kampas tarp gretimų statoriaus fazių yra $\alpha=2 \pi / 6$, o apvijų jungimo būdas yra žvaigždè su viena neutrale, yra aprašomas taip:

$$
\left[\begin{array}{l}
u_{\alpha} \\
u_{\beta} \\
u_{\mathrm{x}} \\
u_{\mathrm{y}} \\
0_{+} \\
0_{-}
\end{array}\right]=\sqrt{\frac{2}{6}}\left[\begin{array}{cccccc}
\cos 0 & \cos \alpha & \cos 2 \alpha & \cos 3 \alpha & \cos 4 \alpha & \cos 5 \alpha \\
\sin 0 & \sin \alpha & \sin 2 \alpha & \sin 3 \alpha & \sin 4 \alpha & \sin 5 \alpha \\
\cos 0 & \cos 2 \alpha & \cos 4 \alpha & \cos 6 \alpha & \cos 8 \alpha & \cos 10 \alpha \\
\sin 0 & \sin 2 \alpha & \sin 4 \alpha & \sin 6 \alpha & \sin 8 \alpha & \sin 10 \alpha \\
\frac{1}{\sqrt{2}} & \frac{1}{\sqrt{2}} & \frac{1}{\sqrt{2}} & \frac{1}{\sqrt{2}} & \frac{1}{\sqrt{2}} & \frac{1}{\sqrt{2}} \\
\frac{1}{\sqrt{2}} & -\frac{1}{\sqrt{2}} & \frac{1}{\sqrt{2}} & -\frac{1}{\sqrt{2}} & \frac{1}{\sqrt{2}} & -\frac{1}{\sqrt{2}}
\end{array}\right]\left[\begin{array}{l}
u_{\mathrm{A}} \\
u_{\mathrm{B}} \\
u_{\mathrm{C}} \\
u_{\mathrm{D}} \\
u_{\mathrm{E}} \\
u_{\mathrm{F}}
\end{array}\right],
$$

čia $u_{i}, 0_{j}-$ ittampos.

Naudingą variklio srautą ir elektromagnetinị sukimo momentą kuria $\alpha-\beta$ maitinimo įtampos dedamosios (Mansour et al. 2008). Paskutiniosios dvi eilutės išreiškia nulines dedamąsias. Disertacijoje nagrinètas tipinis statoriaus nulinio taško jungimo atvejis - neutralè yra izoliuota, todèl šios dedamosios tirtoje sistemoje neegzistuoja.

$x-y$ dedamụjų porų lygtys yra visiškai atskirtos nuo kitų dedamujų įskaitant statoriaus-rotoriaus ryšius (Mansour et al. 2008). Šios dedamosios nedaro ịtakos sukimo momentui, kai mašinos konstrukcija yra simetrinè. Jų poveikis pasireiškia tik esant skirtingoms fazinėms maitinimo įtampoms. $\alpha-\beta$ dedamųjų forma panaši ị trifazès mašinos. 
Galutinès šešiafazio variklio statoriaus ịtampų lygtys, remiantis aukščiau pateiktomis prielaidomis:

$$
\left[\begin{array}{l}
u_{\alpha s} \\
u_{\beta s}
\end{array}\right]=\sqrt{\frac{1}{3}}\left[\begin{array}{cccccc}
1 & \cos \alpha & \cos 2 \alpha & \cos 3 \alpha & \cos 4 \alpha & \cos 5 \alpha \\
0 & \sin \alpha & \sin 2 \alpha & \sin 3 \alpha & \sin 4 \alpha & \sin 5 \alpha
\end{array}\right]\left[\begin{array}{l}
u_{\mathrm{A}} \\
u_{\mathrm{B}} \\
u_{\mathrm{C}} \\
u_{\mathrm{D}} \\
u_{\mathrm{E}} \\
u_{\mathrm{F}}
\end{array}\right] .
$$

Apibrěžto narvelinio rotoriaus atitikmens įtampų lygtys $\alpha-\beta$ koordinačių sistemoje:

$$
\left[\begin{array}{l}
u_{\alpha r} \\
u_{\beta r}
\end{array}\right]=\sqrt{\frac{2}{3}}\left[\begin{array}{ccc}
1 & \cos 2 \alpha & \cos 4 \alpha \\
0 & \sin 2 \alpha & \sin 4 \alpha
\end{array}\right]\left[\begin{array}{l}
u_{\mathrm{a}} \\
u_{\mathrm{b}} \\
u_{\mathrm{c}}
\end{array}\right]
$$

1.5 formule aprašius narvelinio rotoriaus lygtis, $\alpha$ r ir $\beta r$ ịtampos dedamosios prilyginamos nuliams, nes rotorius neturi išorinio maitinimo šaltinio.

Kai elektriniai variklio modelio ịejimo dydžiai yra suprastinami ị dvimatès plokštumos projekcijas, kitos išraiškos sutampa su trifazị variklị aprašančiomis išraiškomis. Statoriaus ịtampų balanso lygtys statoriaus atžvilgiu nejudamoje $\alpha-\beta$ koordinačių sistemoje yra šios (Bose 2002; Miranda et al. 2007; Kianinezhad et al. 2008b):

$$
\left\{\begin{array}{l}
u_{\alpha \mathrm{s}}=R_{\mathrm{s}} i_{\alpha \mathrm{s}}+\frac{\mathrm{d}}{\mathrm{d} t} \Psi_{\alpha \mathrm{s}}, \\
u_{\beta \mathrm{s}}=R_{\mathrm{s}} i_{\beta \mathrm{s}}+\frac{\mathrm{d}}{\mathrm{d} t} \Psi_{\beta \mathrm{s}} .
\end{array}\right.
$$

Atitinkamai rotoriaus įtampų balanso lygtys nejudamoje $\alpha-\beta$ koordinačių sistemoje yra šios:

$$
\left\{\begin{array}{l}
u_{\alpha \mathrm{r}}=R_{\mathrm{r}} i_{\alpha \mathrm{r}}+\frac{\mathrm{d}}{\mathrm{d} t} \Psi_{\alpha \mathrm{r}}-\omega_{\mathrm{r}} \Psi_{\beta \mathrm{r}}, \\
u_{\beta \mathrm{r}}=R_{\mathrm{r}} i_{\beta \mathrm{r}}+\frac{\mathrm{d}}{\mathrm{d} t} \Psi_{\beta \mathrm{r}}+\omega_{\mathrm{r}} \Psi_{\alpha \mathrm{r}} .
\end{array}\right.
$$


Dažnai literatūroje sutinkamas matematinis variklio modelis sinchroniniu greičiu besisukančioje koordinačių sistemoje d-q (Nategh et al., 2008; Abu-Rub et al. 2012; Microsemi 2013; Baltatanu et al. 2013). Jis gaunamas pritaikius Parko transformaciją 1.6 ir 1.7 formulèms. Ittampų transformacijos lygtys yra šios:

$$
\begin{gathered}
{\left[\begin{array}{l}
u_{\mathrm{ds}} \\
u_{\mathrm{qs}}
\end{array}\right]=\left[\begin{array}{cc}
\cos \theta_{\mathrm{s}} & \sin \theta_{\mathrm{s}} \\
-\sin \theta_{\mathrm{s}} & \cos \theta_{\mathrm{s}}
\end{array}\right]\left[\begin{array}{l}
u_{\mathrm{\alpha s}} \\
u_{\beta \mathrm{s}}
\end{array}\right],} \\
{\left[\begin{array}{l}
u_{\mathrm{dr}} \\
u_{\mathrm{qr}}
\end{array}\right]=\left[\begin{array}{cc}
\cos \theta_{\mathrm{s}} & \sin \theta_{\mathrm{s}} \\
-\sin \theta_{\mathrm{s}} & \cos \theta_{\mathrm{s}}
\end{array}\right]\left[\begin{array}{l}
u_{\mathrm{\alpha r}} \\
u_{\beta \mathrm{r}}
\end{array}\right],} \\
\theta_{\mathrm{s}}=\int \omega_{\mathrm{s}} \mathrm{d} t .
\end{gathered}
$$

Atitinkamai pakinta maitinimo įtampų balanso lygtys, pateiktos 1.6 ir 1.7 formulèse. İvedama srauto dedamoji priklausoma nuo sinchroninio greičio:

$$
\begin{gathered}
\left\{\begin{array}{l}
u_{\mathrm{ds}}=\mathrm{R}_{\mathrm{s}} i_{\mathrm{ds}}+\frac{\mathrm{d}}{\mathrm{d} t} \Psi_{\mathrm{ds}}-\omega_{\mathrm{s}} \Psi_{\mathrm{qs}}, \\
u_{\mathrm{qs}}=\mathrm{R}_{\mathrm{s}} i_{\mathrm{qs}}+\frac{\mathrm{d}}{\mathrm{d} t} \Psi_{\mathrm{qs}}+\omega_{\mathrm{s}} \Psi_{\mathrm{ds}},
\end{array}\right. \\
\left\{\begin{array}{l}
u_{\mathrm{dr}}=\mathrm{R}_{\mathrm{r}} i_{\mathrm{dr}}+\frac{\mathrm{d}}{\mathrm{d} t} \Psi_{\mathrm{dr}}-\left(\omega_{\mathrm{s}}-\omega_{\mathrm{r}}\right) \Psi_{\mathrm{qr}}, \\
u_{\mathrm{qr}}=\mathrm{R}_{\mathrm{r}} i_{\mathrm{qr}}+\frac{\mathrm{d}}{\mathrm{d} t} \Psi_{\mathrm{qr}}+\left(\omega_{\mathrm{s}}-\omega_{\mathrm{r}}\right) \Psi_{\mathrm{dr}} .
\end{array}\right.
\end{gathered}
$$

Sinchroniniu greičiu besisukančios koordinačių plokštumoje sinusiniu dėsniu kintantys dydžiai gali būti išreikšti konstantomis. Taip jis plačiai naudotas ankstyvuose elektros variklių imitaciniuose tyrimuose.

Statoriaus ir rotoriaus srautai randami iš akimirkinių srovių verčių (Renukadevi, Rajambal 2012):

$$
\left\{\begin{array}{l}
\Psi_{\mathrm{ds}}=L_{\mathrm{ls}} i_{\mathrm{ds}}+L_{\mathrm{m}}\left(i_{\mathrm{ds}}+i_{\mathrm{dr}}\right), \\
\Psi_{\mathrm{qs}}=L_{\mathrm{ls}} i_{\mathrm{qs}}+L_{\mathrm{m}}\left(i_{\mathrm{qs}}+i_{\mathrm{qr}}\right), \\
\Psi_{\mathrm{dr}}=L_{\mathrm{lr}} i_{\mathrm{dr}}+L_{\mathrm{m}}\left(i_{\mathrm{ds}}+i_{\mathrm{dr}}\right), \\
\Psi_{\mathrm{qr}}=L_{\mathrm{lr}} i_{\mathrm{qr}}+L_{\mathrm{m}}\left(i_{\mathrm{qs}}+i_{\mathrm{qr}}\right),
\end{array}\right.
$$

Elektromagnetinis sukimo momentas gali būti randamas iš magnetinių srautų arba srovių dedamụjų. Tokių išraiškų yra trys. Nepriklausomai nuo dvifazio modelio koordinačių sistemos, apskaičiuotas sukimo momento dydis turi sutapti. 
Elektromagnetinio sukimo momento išraiška pagal rotoriaus ir statoriaus sroves (Wang et al. 2011):

$$
M_{\mathrm{e}}=\frac{P}{2} L_{\mathrm{m}}\left(i_{\mathrm{qs}} i_{\mathrm{dr}}-i_{\mathrm{ds}} i_{\mathrm{qr}}\right) .
$$

Rotoriaus sukimosi kampinis greitis randamas iš rotorių veikiančių sukimo momentų sumos:

$$
\frac{\mathrm{d} \omega}{\mathrm{d} t}=\frac{1}{J}\left(M_{\mathrm{e}}-M_{\mathrm{st}}\right) .
$$

Pagal pateiktus modelius galima sudaryti kompiuterinius modelius tokia programine ịranga kaip Matlab ir jos paketu Simulink. Vienas iš šešiafazio asinchroninio variklio kompiuterinių modelių sudarytas ir jo adekvatumas tirtas dr. Beno Kundroto disertacijoje.

\subsection{Daugiafazių pavarų valdymo metodai}

Daugiafazių mašinų valdymui galima pritaikyti visus trifazių mašinų valdymo metodus ir būdus. Galima išskirti du pagrindinius asinchroninių variklių valdymo metodus: skaliarinị ir vektorinị (Kohlrusz, Fodor 2011). Skaliarinis valdymo metodas, kai kuriuose šaltiniuose vadinamas $U / f$ valdymo metodu arba valdymas įtampa/dažnis. Toks greičio reguliavimo metodas, dažnio keitikliu keičia variklio maitinimo įtampos dažnį bei amplitudę. Šis valdymo algoritmas yra paprastas ir nereikalauja sudėtingų skaičiavimų. Skaliariniam daugiafazių pavarų valdymui, naudojant įtampos inverterius (Ward, Härer 1969; Abbas et al. 1984; Pavithran et al. 1988) arba srovès inverterius (Andrese, Bieniek 1981; Gopakumar et al. 1984; Dente, Labrique 1985), daugiausiai dėmesio buvo skiriama pačioje tokių pavarų tyrimų pradžioje. Šiuo metu daugiausiai dèmesio skiriama vektoriniam ir tiesioginiam momento ir srauto valdymui.

Didžiausia daugiafazių pavarų taikymo problema yra tai, kad nèra daugiafazio pramoninio tinklo. Dèl šios priežasties dažniausiai daugiafazės pavaros naudojamos autonominėse sistemose, kur specialiais transformatoriais arba inverteriais trifazè sistema pakeičiama ị reikiamą daugiafazę (Renukadevi, Rajambal 2013; Archana, Chudasama 2012). Priklausomai nuo daugiafazio variklio tipo jis gali būti maitinamas iš kelių trifazių dažnio keitiklių arba daugiafazio dažnio keitiklio. Naudojant dažnio keitiklị, keičiant jo išèjimo ịtampos dažnị ir amplitudę galima reguliuoti daugiafazio variklio sukimosi greitị. Dažninių pavarų valdymo metodai parodyti 1.8 paveiksle. 


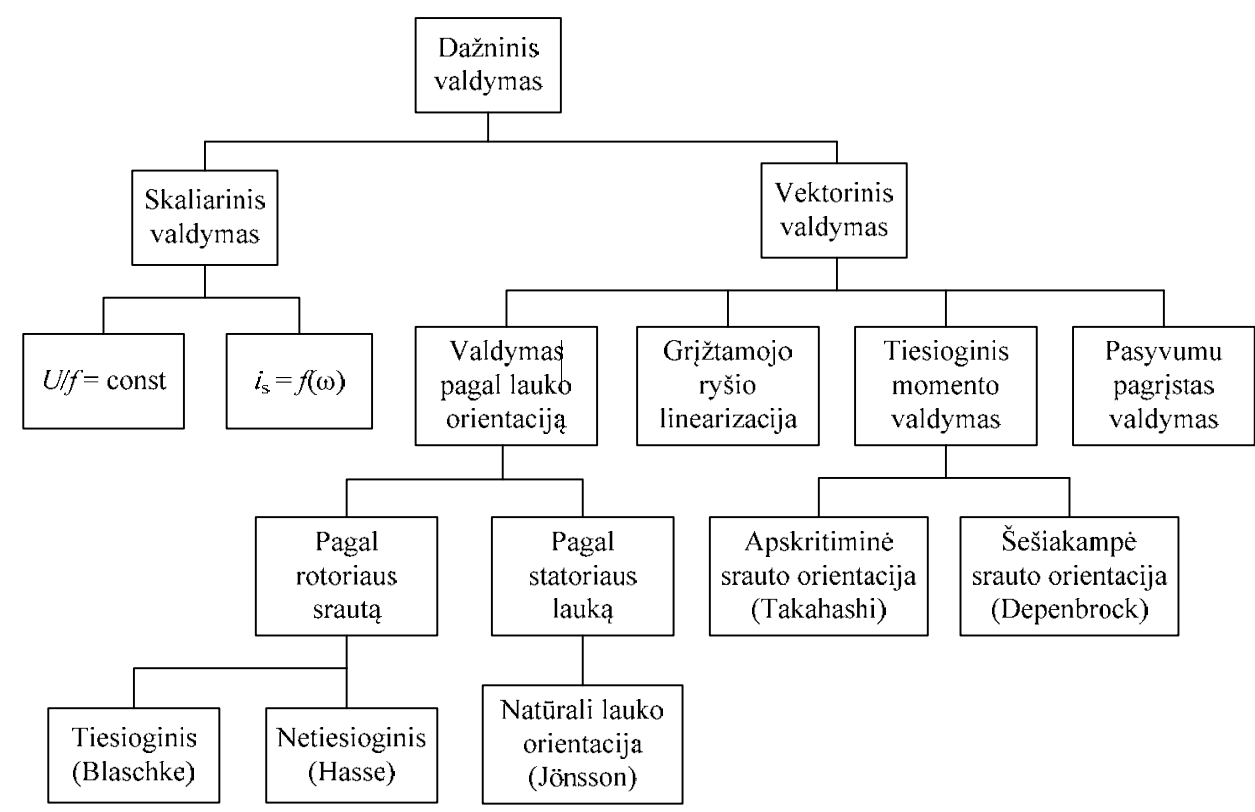

1.8 pav. Asinchroninių pavarų valdymo metodai

Fig. 1.8. Control methods of induction drives

Iš 1.8 paveikslo matyti, kad skaliarinio valdymo būdų yra mažai. Dèl principinio skirtumo nuo vektorinio valdymo, jie yra paprastesni ir lengviau igyvendinami. Jie užtikrina patikimą pavarų darbą, kur nėra keliami labai aukšti valdymo tikslumo reikalavimai.

Vektorinis valdymas (1.8 pav.) gali būti igyvendinamas taikant erdvinio vektoriaus impulsų pločio moduliacijos metodą (angl. Space Vector Pulse Width Modulation, SVPWM). Erdvinio vektoriaus impulsų pločio moduliacijos metodas yra sudètingesnis už skaliariniame valdyme taikomą impulsų pločio moduliacijos metodą, todèl jo iggyvendinimui dažniausiai neužtenka ịprastos įterptinès sistemos su mikrovaldikliu.

Yra du pagrindiniai vektorinio valdymo metodai. Vienas jų vadinamas tiesioginio arba grižtamojo ryšio vektorinio valdymo metodu, kuri aprašè F. Blaschke (Blaschke 1972). Antrasis yra netiesioginio valdymo metodas, kuri atrado Hasse (Hasse 1969). Pagrindinis šių metodų skirtumas yra bazinių vektorių $\cos \left(\theta_{\mathrm{e}}\right)$ ir $\sin \left(\theta_{\mathrm{e}}\right)$ formavimo būdai valdymo signalams formuoti. Srovès komponentės $i_{\mathrm{ds}}$ kryptis gali būti sutapdinama su rotoriaus srautu, srautu oro tarpe arba statoriaus srautu.

Tipinė vektorinio pagal lauką orientuoto valdymo schema penkiafazès pavaros atvejui pateikta 1.9 paveiksle. 


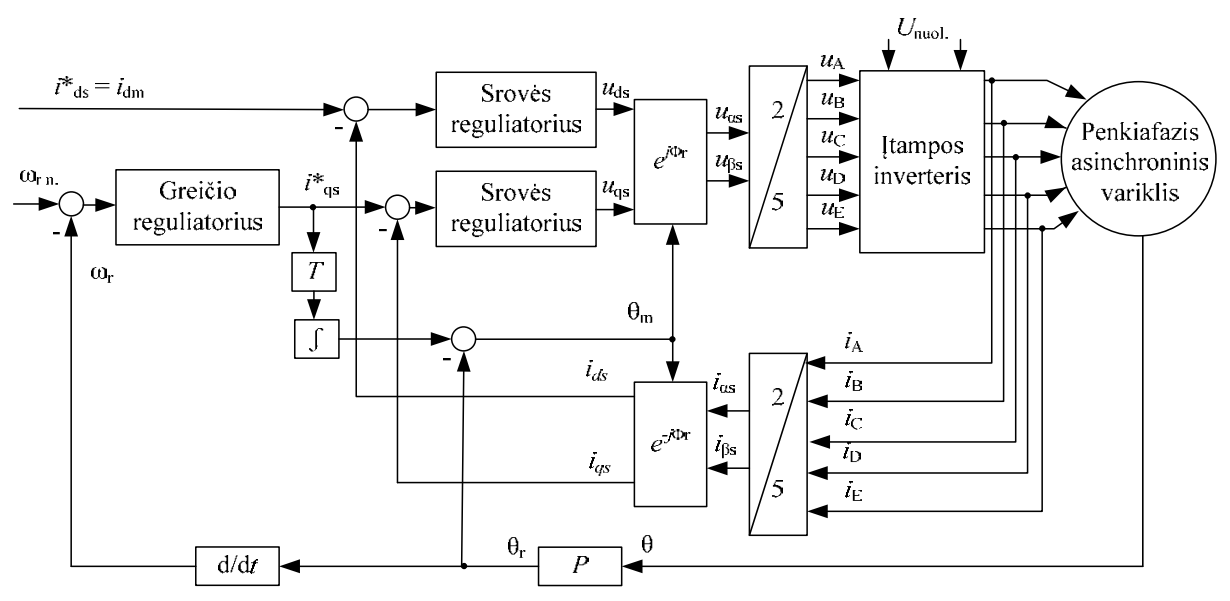

1.9 pav. Netiesioginio pagal rotoriaus srautą orientuoto valdymo penkiafazès asinchroninès pavaros funkcinè schema

Fig. 1.9. Functional block diagram of indirect rotor flux-oriented control five-phase induction drive

Sinchroniniu greičiu besisukančio statoriaus srovių atstojamojo vektoriaus d ir q dedamosios valdomos nepriklausomai. Momento valdymui naudojama statoriaus srovès vektoriaus projekcija ị q, o rotoriaus srauto valdymui - projekcija ị d besisukančios koordinačių sistemos ašis. Orientacija pagal rotoriaus srautą, lyginant su orientacija pagal statoriaus srautą, išpildo tikrą valdymo atskyrimą. Grịžtamojo ryšio signalai naudojami reakcijos padidinimui srovės valdymo kontūruose. Magnetinio srauto grįžtamasis ryšys gali būti įvertintas pagal variklio įtampą ir srovę (esant ịtampos modeliui) arba pagal srovę ir greitị (esant srovès modeliui). Esant vektoriniam ịtampos modeliui variklis veikia gerai virš $2 \%$ pradinio greičio zonoje, bet srovės modelyje gali veikti nuo nulinio greičio.

Variklio parametrų pokyčiams jautresnis yra srovės modelis. Šiame modelyje srautas gali būti paprastai valdomas atvirajame kontūre kaip funkcija nuo statoriaus srovès d dedamosios. Pavara gali būti naudojama nuo nulinio greičio iki magnetinio lauko susilpnèjimo srities. Pastarasis vektorinio valdymo metodas ypač populiarus pramonèje, bet variklio parametrų pokyčiai turi įtakos slydimui ir, atitinkamai, pavaros dinaminėms ir statinėms charakteristikoms, o tai yra nemenkas trūkumas. Pirminis derinimas turi būti atliekamas dažnio keitiklio autonominiu parametrų matavimu. Valdymo metu kintant variklio parametrams, derinimas tampa labai sudètingas.

Supaprastinta netiesioginio vektorinio pagal rotoriaus srautą orientuoto valdymo būdo funkcinè schema pateikta 1.10 paveiksle. 


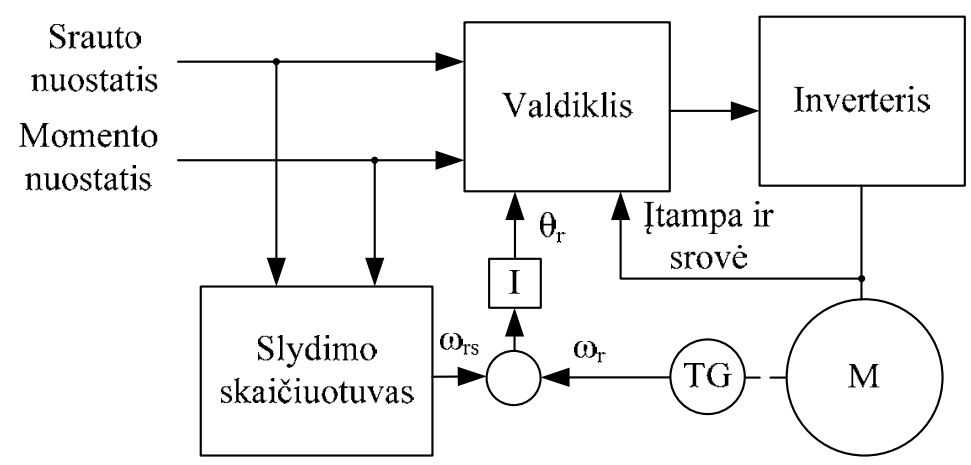

1.10 pav. Supaprastinta netiesioginio pagal rotoriaus srautą orientuoto vektorinio valdymo funkcinè schema

Fig. 1.10. Functional block diagram of simplified indirect rotor fluxoriented control

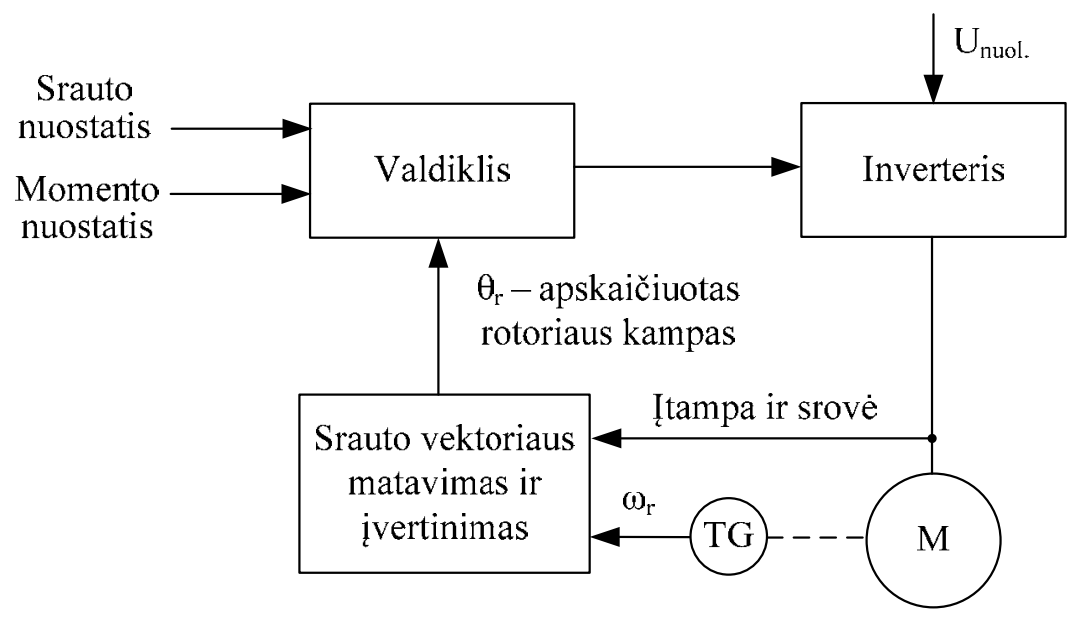

1.11 pav. Supaprastinta tiesioginio pagal rotoriaus srautą orientuoto vektoriaus valdymo funkcinè schema

Fig. 1.11. Functional block diagram of simplified direct rotor flux-oriented control

Tiesioginio rotoriaus srauto vektoriaus valdymo metodo funkcinè schema pavaizduota 1.11 paveiksle. Visi pagrindiniai valdymo elementai tokie pat kaip ir netiesioginiame valdyme. Pagal ịtampos ir srovès signalus galima ịvertinti greičio signalą. Srauto vektorius ịtampos modelyje negali būti apskaičiuotas prie žemų, 
artimų nuliui, greičių, tačiau srovės modeliuose tai nesudètingai gali būti realizuojama (Bojoi et al. 2010).

Šis valdymas yra mažai jautrus variklio parametrų pokyčiams. Pavyzdžiui, srauto vektoriaus signalas gaunamas integruojant įtampą. Tiesioginio momento valdymo modelis yra jautrus tik statoriaus varžos pokyčiams, o tai kompensuoti yra nesudètinga.

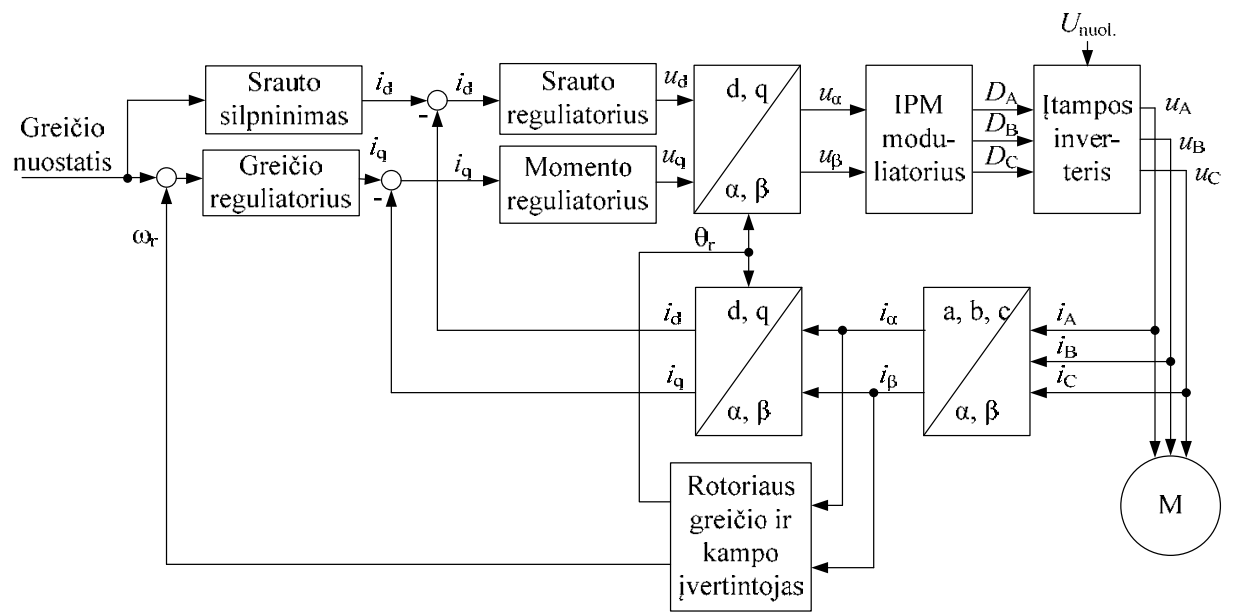

1.12 pav. Tiesioginio momento valdymo trifazės pavaros funkcinė schema

Fig. 1.12. Functional block diagram of direct torque control three-phase drive

1.12 paveiksle matyti, kad yra dvi grandinès, atitinkančios statoriaus srauto ir momento dydžius. Statoriaus srauto modulio ir momento nustatymo signalai lyginami su esamomis vertemis ir jų skirtumai perduodami atitinkamai ị dviejų ar trijų lygių histerezès blokus. Šių valdiklių išejimai kartu su statoriaus lauko padèties signalu yra perduodami į vektorių parinkimo lentelę. Statoriaus srauto padètis suskirstyta $\mathfrak{i}$ šešis nepriklausomus sektorius. Statoriaus srauto modulio ir momento paklaidos apribotos atitinkamose histerezès kilpose.

Neraiškioji logika yra priemonè netiesiniams reguliatoriams sudaryti. Neraiškioji logika yra skirta matematiškai apibrèžti objektų klases, kurios neturi griežtai ir aiškiai apibrèžto sąryšio. Jos pradininkas, prof. Lofti A. Zadeh argumentavo, jog žmonėms nereikia tikslios ir aiškios informacijos tam, kad šie galètų produktyviai vykdyti valdymą. Jeigu valdiklius pavyktų užprogramuoti veikti panašiai, tai yra priimti nevisai tikslią ir neretai informaciją su triukšmais, šie taptų efektyvesni ir lengviau ịdiegiami (Zadeh 1965). 
Neraiškioji logika yra taikoma nestandartinèms valdymo sistemų problemoms spręsti (Sheidaei et al. 2007). Ji diegiama ị ịvairias sistemas pradedant nuo paprastų bei mažų ịterptinių mikrovaldiklių iki didelių, tinklinių, daugiakanalių asmeninių kompiuterių ar valdymo sistemų. Neraiškioji logika gali būti ịgyvendinta techninèje įrangoje, programinejje įrangoje ar mišrioje sistemoje (Boldea, Nasar 2005).

Neraiškiosios logikos valdymo sistemų privalumus galima trumpai apibūdinti taip (Reznik 1997):

- neraiškiają logiką lengva suprasti. Taikant lingvistinius, o ne skaitinius dydžius, matematinis aparatas labai paprastas ir natūraliai suvokiamas;

- galima naudoti netikslius duomenis. Išèjime gaunama glotni ir lygi valdymo funkcija nepaisant plataus įèjimo dydžio kitimo diapazono;

- neraiškioji logika yra lanksti. Turint sudarytą valdymo sistemą, ją paprasta papildyti naujais funkciniais objektais;

- neraiškiosios logikos sistemos yra patikimos ir pigios;

- neraiškioji logika gali būti suderinta su ịprastine valdymo metodika, pavyzdžiui PID reguliatoriumi. Neraiškiosios logikos sistemos nebūtinai ją pakeičia, o dažniausiai papildo ir supaprastina pritaikomumą;

- viena iš svarbiausiųjų neraiškiosios logikos savybių ir jos pagrindas yra žmogiškosios komunikacijos taikomumas. Žmonių kasdienė kalba yra patogi, ịprasta, efektyvi ir lengvai suprantama.

- Neraiškiosios logikos modeliai gali remtis ekspertų sukauptomis žiniomis apie sistemą, jo patirtimi ir netgi intuicija;

- neraiškioji logika yra neapribota keliais grižtamosios grandies įejjimais ir vienu ar keliais valdymo signalų išèjimais;

- kadangi neraiškiosios logikos valdiklis apdirba vartotojo apibrěžtas taisykles valdymo sistemai, tai šios gali būti keičiamos lengvai siekiant pagerinti ar pakeisti sistemos veikimą;

- galima valdyti netiesines sistemas, kurias sumodeliuoti matematiškai yra sunku ar neįmanoma.

Neraiškiąja logika pagrịstų valdomų sistemų trūkumai (Boldea, Nasar 2005):

- Sunku sudaryti neraiškiosios logikos sistemos matematinį modelį.

- Sudètingesnis sistemos derinimas.

- Sunku pasirinkti priklausomybès funkcijų ir taisyklių kiekį.

- Sudėtingų sistemų valdyme išauga priklausomybių funkcijų ir taisyklių skaičius, tampa sudètingiau sudaryti reguliatorių, kuris reikalauja daugiau darbinių resursų.

Nepaisant trūkumų neraiškioji logika plačiai naudojama įvairiose sudètingose sistemose, kamerose su automatiniu fokusavimu, skalbimo mašinose, kurios gali 
nuspręsti ir sureguliuoti skalbimo ciklą priklausomai nuo to kaip smarkiai ištepti drabužiai yra skalbiami, taip pat elektros energetikoje, laivų navigacijoje, cemento gamyboje, automobiliuose pastoviam greičiui palaikyti, pavarai automatiškai perjungti priklausomai nuo variklio apkrovos, stabdžių antiblokavimo sistemose, metro valdymo sistemose, taip pat kompiuterinèse programose, ekonomikoje, psichologijoje, rinkodaroje, orų prognozėse, biologijoje, politikoje ir kitose didelèse ir sudètingose sistemose.

Neraiškiosios logikos valdiklio tipinè funkcinè schema kartu su valdomuoju objektu pavaizduota 1.13 paveiksle (Boldea, Nasar 2005).

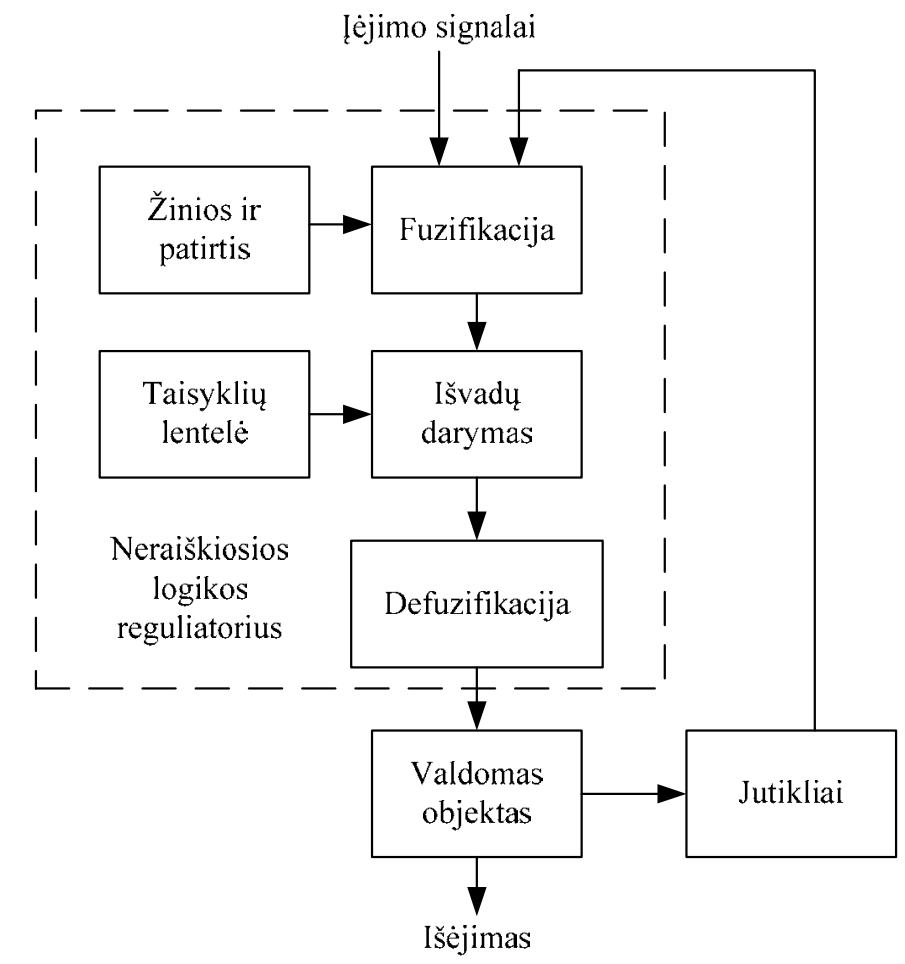

1.13 pav. Uždara valdymo sistema su neraiškiosios logikos reguliatoriumi funkcinè schema

Fig. 1.13. Functional block diagram of closed-loop system with a fuzzy logic controller

Fuzifikacijos blokas aiškias valdymo įèjimų vertes paverčia į neraiškiosios logikos vertes taip, kad šios atitiktų neraiškiąsias aibes aprašytas taisyklių lentelejje. Paimamos įejjimų vertès ir nustatomos jų priklausomybės neraiškiosioms aibèms laipsnis. 
Žinių bazès blokas susideda iš informacinès bazès apie valdomą objektą. Jis suteikia visus reikalingus (priklausomybès funkcijos, neraiškiųjų aibių priklausomybès nuo įejjimo-išèjimo verčių ir kt.) apibrèžimus fuzifikacijos procesui.

Taisyklių bazė arba kitaip - taisyklių lentelè yra pagrindinis dalykas nusakantis sistemos valdymą. Ji paprastai sudaroma remiantis ekspertų patirtimi ir išreiškiama kaip aibè taisyklių „Jei-Tai“.

Pagal taisyklių lentelę ir gautus įejimo duomenis yra nusprendžiama kaip geriausia valdyti valdomaji i objektą.

Defuzifikacija yra atvirkštinis veiksmas fuzifikacijai, kuomet iš neraiškiosios aibės gaunama tradicinès matematikos skaitinè reikšmė - atsakymas. Dažniausiai naudojami šie defuzifikacijos metodai:

- centro (angl. center of gravity, CoG);

- $\quad$ aukščio (angl. height method, HM);

- maksimumo vidurio (angl. mean of maximum, MoM);

- $\quad$ pirmojo maksimumo (angl. first of maximum, FoM).

Defuzifikacijos metodus galima palyginti pagal tai, ar išèjimai yra nuolatiniai ir pagal apskaičiavimų sudetingumą.

\subsection{Pirmojo skyriaus išvados ir disertacijos uždavinių formulavimas}

1. Daugiafaziams asinchroniniams varikliams valdyti ir tirti galima pritaikyti trifazių pavarų valdymo būdus, įskaitant rotoriaus srauto vektoriaus valdymo ir tiesioginį momento valdymo būdą.

2. Trifaziai varikliai neturi nutrūkusios fazès poavarinio režimo kompensavimo metodų. Daugiafaziai varikliai poavarinio režimo metu užtikrina sąlyginai didelę galią ir taikant tinkamus kompensatorius užtikrina saugų ilgalaikị darbą.

3. Poavarinio režimo atveju kompensuojami statoriaus srovių sistemos iškraipymai: išaugusios fazinės srovès, galinčios pakenkti variklio statoriaus apvijoms ir galio keitikliui, taip pat srovių atstojamojo trajektorijos elipsiškumas, kuris sukelia elektromagnetinio momento pulsacijas, nèra pakankamai ištirti.

4. Neraiškiosios logikos reguliatoriai yra netiesiniai ir kuriami naudojant ekspertines žinias. Naudojant eksperimentų metu gautas žinias, galima tobulinti daugiafazių elektros pavarų, veikiančių ịvairiais darbo režimais, įskaitant poavariniais, valdymą. 
Atlikus literatūros analizę, suformuluoti šie disertacijos uždaviniai:

1. Sukurti neraiškiosios logikos reguliatorių vektoriniam tiesioginio momento valdymo būdui, kuris pagerintų daugiafazès pavaros dinamines charakteristikas.

2. Sukurti paieškos metodą, leidžiantị rasti statoriaus įtampų fazinius kampus, kuriais kompensuojami poavarinio režimo padariniai.

3. Sukurti reguliatorių, kompensuojantị poavarinio režimo metu pasireiškiančius viršsrovius ir statoriaus srovių atstojamojo vektoriaus elipsinę trajektoriją. 


\section{Šešiafazių pavarų modeliavimas ir valdymas esant normaliajam režimui}

Šiame skyriuje pateikti daugiafazių asinchroninių pavarų modeliavimo rezultatai. Sumodeliuotų pavarų valdymui buvo pritaikyti trifazių variklių valdymo būdai. Daugiausia dèmesio skiriama šešiafazès sistemos modeliavimui.

Skyriaus tematika paskelbti du straipsniai (Rinkevičienè, Savickienė, Uznys, Pitrėnas, Šlepikas 2017; Lisauskas, Udris, Uznys 2013).

\subsection{Imitaciniai šešiafazio variklio ir pavaros bandymai}

Daugiafazio variklio modeli galima sudaryti netaikant pirmajame skyriuje pateiktų projekcijų ị dvifazę sistemą. Taikant daugiafazị (netransformuotą) modelị gaunama aiškesnè sistema, tinkama tyrimams dèl galimybès matuoti visus tarpinius būsenos kintamuosius be papildomų matematinių operacijų.

Elektrotechninių procesų, vykstančių varikliuose, skaičius yra nepriklausomas nuo fazių skaičiaus. Daugiafazio variklio matematinis ir tuo pačiu imitacinis modelis yra labai panašus ị trifazio variklio. Šis modelis yra pateiktas 2.1 paveiksle. 


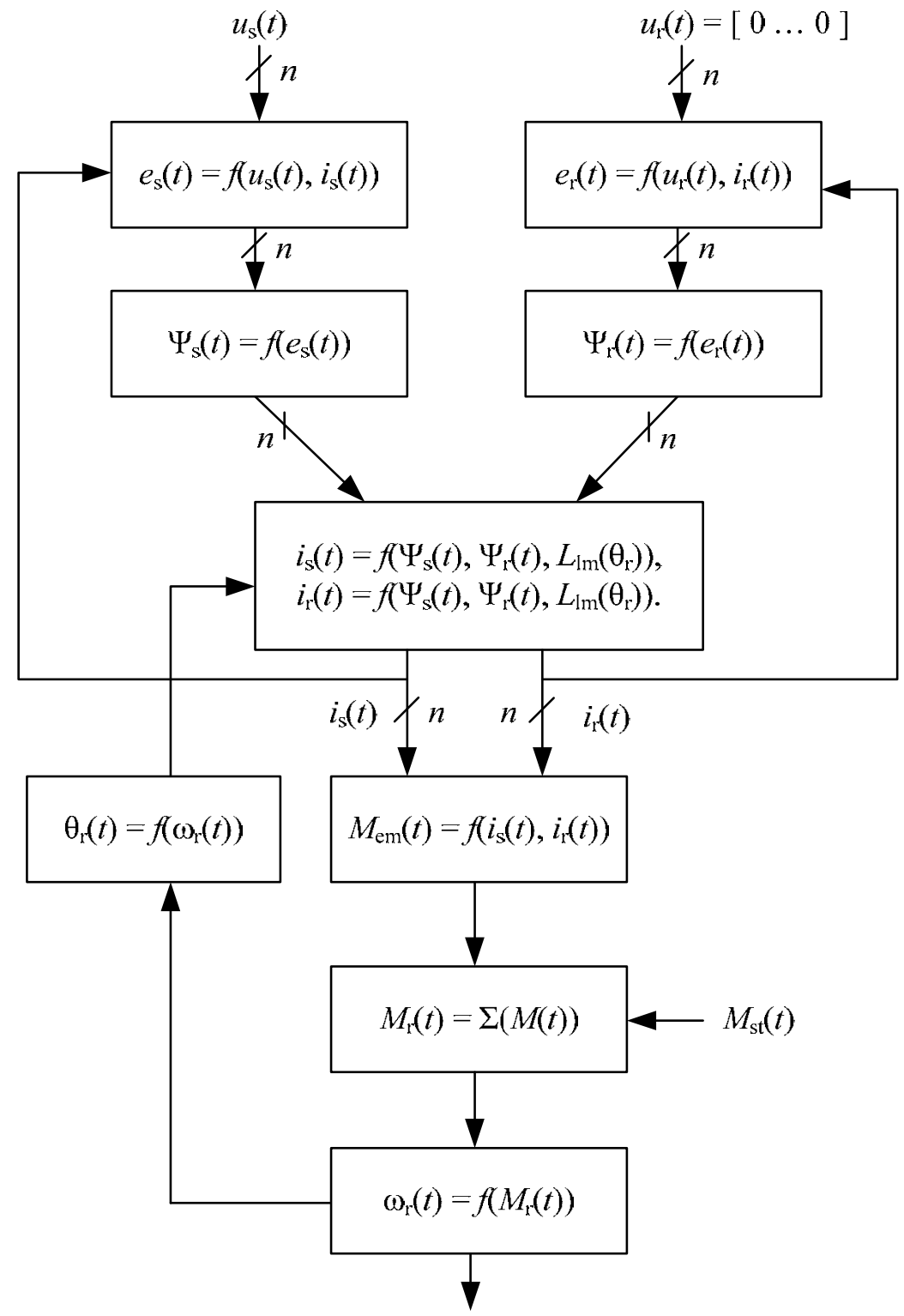

2.1 pav. Daugiafazio asinchroninio variklio imitacinio modelio daugiafazèje koordinačių sistemoje funkcinè schema

Fig. 2.1. Functional block diagram of multi-phase induction machine computer model in multi-dimensional reference frame 
2.1 paveiksle matyti, kad reikia atlikti daug skirtingų matematinių skaičiavimų variklio sukimosi greičiui iš maitinimo įtampų ir apkrovos momento apskaičiuoti. Apkrovos momentas pasireiškia slydimu, o šis pasireiškia įtampų kryčiais. Daugelis schemoje žymimų dydžių yra vektoriai, kurių dydis yra lygus statoriaus arba rotoriaus fazių skaičiui. 2.1 paveiksle pateiktas modelis yra daugiafazis - sistemos kintamieji nėra transformuojami ị tokias dvifazes koordinačių sistemas, kaip pateikta pirmojo skyriaus modelių apžvalgoje.

Formuojamos ịtampos ị modeli pateikiamos tiesiogiai, neatliekant matematinių operacijų jų performuoti ar kitaip apdoroti. Tyrimams apsiribojama šešiafazio variklio atveju. Nepriklausomai nuo taikomo matematinio modelio - daugiafazio ar dvifazio - įejjimo įtampos išreiškiamos vektoriais stulpeliais:

$$
\begin{gathered}
u_{\mathrm{s}}(t)=\left[\begin{array}{llllll}
u_{\mathrm{A}}(t) & u_{\mathrm{B}}(t) & u_{\mathrm{C}}(t) & u_{\mathrm{D}}(t) & u_{\mathrm{E}}(t) & u_{\mathrm{F}}(t)
\end{array}\right]^{\mathrm{T}}, \\
u_{\mathrm{r}}(t)=\left[\begin{array}{llllll}
u_{\mathrm{a}}(t) & u_{\mathrm{b}}(t) & u_{\mathrm{c}}(t) & u_{\mathrm{d}}(t) & u_{e}(t) & u_{\mathrm{f}}(t)
\end{array}\right]^{\mathrm{T}} .
\end{gathered}
$$

Tiriamas variklis yra asinchroninis su narveliniu rotoriumi, todèl visos rotoriaus maitinimo įtampos formuleje 2.2 yra lygios nuliui. Tai supaprastina pavaros modelị, nes vieninteliai ịejjimo signalai yra maitinimo ịtampos ir vienas apkrovos momento dydis.

Narvelinis rotorius neturi šešių fazių ir gali būti reprezentuojamas kaip mfazis, kur $m$ yra 2 ir daugiau. Siekiant modelị palikti lengviau suprantamą, narvelinio rotoriaus virtualių fazių skaičius prilyginamas statoriaus fazių skaičiui (2.2 formulè). Mažesnis koordinačių skaičius padidintų operacijų su matricomis spartą, tačiau sumažintų modelio aiškumą, intuityvumą. Svarbu pastebėti, kad nuo imituojamo rotoriaus fazių skaičiaus priklauso ir imituojamo variklio parametrai. Patartina netiesiogiai matuojamus rotoriaus parametrus identifikuoti pagal galutinai apibrèžtas matematines lygtis.

Statoriaus ir rotoriaus akimirkinės srovės sudaro analogiškus vektorius ịtampai:

$$
\begin{gathered}
i_{\mathrm{S}}(t)=\left[\begin{array}{llllll}
i_{\mathrm{A}}(t) & i_{\mathrm{B}}(t) & i_{\mathrm{C}}(t) & i_{\mathrm{D}}(t) & i_{\mathrm{E}}(t) & i_{F}(t)
\end{array}\right]^{\mathrm{T}}, \\
i_{\mathrm{r}}(t)=\left[\begin{array}{llllll}
i_{\mathrm{a}}(t) & i_{\mathrm{b}}(t) & i_{\mathrm{C}}(t) & i_{\mathrm{d}}(t) & i_{\mathrm{e}}(t) & i_{\mathrm{f}}(t)
\end{array}\right]^{\mathrm{T}} .
\end{gathered}
$$

Daugiafazio matematinio modelio srovių išraiškos (2.3 ir 2.4 formulès) yra patogesne forma negu dvifazio modelio atveju. Tokios išraiškos užtikrintų greitą modelio pritaikymą uždaro valdymo pavarų modeliavimui. Pavyzdžiui, pagal lauką orientuoto valdymo atveju, kur reikia daug ịvairių dinaminių variklio dy- 
džių. Jei pasitelkiamas modelis statoriaus atžvilgiu nejudamoje koordinačių sistemoje, statoriaus ir rotoriaus srovės turètų po dvi komponentes, kurias būtina transformuoti.

Elektrovara skaičiuojama taip:

$$
\begin{aligned}
& e_{\mathrm{S}}(t)=u_{\mathrm{S}}(t)-R_{\mathrm{S}} \cdot i_{\mathrm{S}}(t), \\
& e_{\mathrm{r}}(t)=u_{\mathrm{r}}(t)-R_{\mathrm{r}} \cdot i_{\mathrm{r}}(t) .
\end{aligned}
$$

Elektrovaros skaičiavimas (2.5 ir 2.6 formulès) yra pirmoji operacija pateiktoje funkcinejje schemoje 2.1 pav. Nors operacija atrodo paprasta, tačiau tai yra dalis algebrinès kilpos, kuri neturi analizinio sprendinio - visa sistema yra netiesinè. Čia elektrovaroms apskaičiuoti reikalingos srovès, kurioms reikalingi - srautai, kuriems reikalingas rotoriaus kampas, kuriam reikalingos - tos pačios srovės srautams gauti. Imitaciniai rezultatai gaunami taikant tik skaitinius sprendimo metodus.

Daugiafaziame modelyje kiekvienos fazès varža nurodoma atskirai suformuojant ịstrižinę matricą:

$$
\begin{aligned}
& R_{\mathrm{S}}=\operatorname{diag}\left(R_{\mathrm{A}} \quad R_{\mathrm{B}} \quad R_{\mathrm{C}} \quad R_{\mathrm{D}} \quad R_{\mathrm{E}} \quad R_{\mathrm{F}}\right), \\
& R_{\mathrm{r}}=\operatorname{diag}\left(R_{\mathrm{a}} \quad R_{\mathrm{b}} \quad R_{\mathrm{c}} \quad R_{\mathrm{d}} \quad R_{\mathrm{e}} \quad R_{\mathrm{f}}\right) .
\end{aligned}
$$

Pirmajame ir antrajame skyriuose pateikti matematiniai modeliai skirti simetriniams asinchroninių variklių režimams tirti. Dèl šios priežasties statoriaus ir rotoriaus kuriamų srauto dedamųjų išraiškos yra idealizuotos:

$$
\begin{aligned}
& \Psi_{\mathrm{S}}(t)=\int e_{\mathrm{S}}(t) \mathrm{d} t, \\
& \Psi_{\mathrm{r}}(t)=\int e_{\mathrm{r}}(t) \mathrm{d} t,
\end{aligned}
$$

Apskaičiavus statoriaus ir rotoriaus magnetinius srautus galima išreikšti srovei, kurių verčių reikia pirmosios operacijoms (2.5 ir 2.6 formulès):

$$
\begin{aligned}
& \Psi_{\mathrm{s}}(t)=L_{\mathrm{ss}} \cdot i_{\mathrm{S}}(t)+L_{\mathrm{sr}}\left(\theta_{\mathrm{r}}\right) \cdot i_{\mathrm{r}}(t), \\
& \Psi_{\mathrm{r}}(t)=L_{\mathrm{r}} \cdot i_{\mathrm{r}}(t)+L_{\mathrm{rs}}\left(\theta_{\mathrm{r}}\right) \cdot i_{\mathrm{S}}(t) .
\end{aligned}
$$

Lygiai taip pat kaip srovių atveju, magnetiniai srautai nèra transformuoti i dvifazę koordinačių sistemą. Tokia forma jas patogu tirti, pavyzdžiui, atliekant nesimetrinių maitinimo įtampų bandymus.

Kaip ir aktyviosios varžos atveju (2.7 ir 2.8 formulès), induktyvumas nurodomas kiekvienai apvijai atskirai. $L_{\text {ss }}$ yra abipusis induktyvumas tarp kiekvienos fazès, ịskaitant tos fazès sklaidos induktyvumą. Šešiafaziame gaunama matrica su 36 reikšmèmis: 


$$
\begin{aligned}
& L_{\mathrm{ss}}=\left[\begin{array}{ccc}
L_{\mathrm{ls}}+L_{\mathrm{m}} & L_{\mathrm{m}} \cdot \cos \alpha & L_{\mathrm{m}} \cdot \cos 2 \alpha \\
L_{\mathrm{m}} \cdot \cos 5 \alpha & L_{\mathrm{ls}}+L_{\mathrm{m}} & L_{\mathrm{m}} \cdot \cos \alpha \\
L_{\mathrm{m}} \cdot \cos 4 \alpha & L_{\mathrm{m}} \cdot \cos 5 \alpha & L_{\mathrm{ls}}+L_{\mathrm{m}} \\
L_{\mathrm{m}} \cdot \cos 3 \alpha & L_{\mathrm{m}} \cdot \cos 4 \alpha & L_{\mathrm{m}} \cdot \cos 5 \alpha \\
L_{\mathrm{m}} \cdot \cos 2 \alpha & L_{\mathrm{m}} \cdot \cos 3 \alpha & L_{\mathrm{m}} \cdot \cos 4 \alpha \\
L_{\mathrm{m}} \cdot \cos \alpha & L_{\mathrm{m}} \cdot \cos 2 \alpha & L_{\mathrm{m}} \cdot \cos 3 \alpha
\end{array}\right. \\
& L_{\mathrm{m}} \cdot \cos 3 \alpha \quad L_{\mathrm{m}} \cdot \cos 4 \alpha \quad L_{\mathrm{m}} \cdot \cos 5 \alpha \\
& L_{\mathrm{m}} \cdot \cos 2 \alpha \quad L_{\mathrm{m}} \cdot \cos 3 \alpha \quad L_{\mathrm{m}} \cdot \cos 4 \alpha \\
& L_{\mathrm{m}} \cdot \cos \alpha \quad L_{\mathrm{m}} \cdot \cos 2 \alpha \quad L_{\mathrm{m}} \cdot \cos 3 \alpha
\end{aligned}
$$

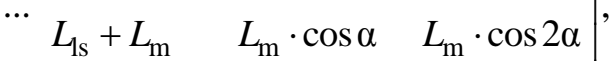

$$
\begin{aligned}
& L_{\mathrm{m}} \cdot \cos 5 \alpha \quad L_{\mathrm{ls}}+L_{\mathrm{m}} \quad L_{\mathrm{m}} \cdot \cos \alpha \\
& L_{\mathrm{m}} \cdot \cos 4 \alpha \quad L_{\mathrm{m}} \cdot \cos 5 \alpha \quad L_{\mathrm{ls}}+L_{\mathrm{m}}
\end{aligned}
$$

čia $\alpha$ - erdvinis kampas tarp gretimų apvijų.

Apsiribota simetriniu statoriaus apvijų išdėstymu, kur kampas tarp visų gretimų apvijų yra 60 elektrinių laipsnių.

Dèl sprendimo rotoriaus virtualių apvijų skaičių prilyginti statoriaus vertei, rotoriaus induktyvumo matrica yra beveik identiška. Skiriasi tik sklaidos induktyvumo verte $-L_{\mathrm{lr}}$ vietoje $L_{\mathrm{ls}}$ :

$$
\begin{aligned}
& L_{\mathrm{rr}}=\left[\begin{array}{ccc}
L_{\mathrm{lr}}+L_{\mathrm{m}} & L_{\mathrm{m}} \cdot \cos \alpha & L_{\mathrm{m}} \cdot \cos 2 \alpha \\
L_{\mathrm{m}} \cdot \cos 5 \alpha & L_{\mathrm{lr}}+L_{\mathrm{m}} & L_{\mathrm{m}} \cdot \cos \alpha \\
L_{\mathrm{m}} \cdot \cos 4 \alpha & L_{\mathrm{m}} \cdot \cos 5 \alpha & L_{\mathrm{lr}}+L_{\mathrm{m}} \\
L_{\mathrm{m}} \cdot \cos 3 \alpha & L_{\mathrm{m}} \cdot \cos 4 \alpha & L_{\mathrm{m}} \cdot \cos 5 \alpha \\
L_{\mathrm{m}} \cdot \cos 2 \alpha & L_{\mathrm{m}} \cdot \cos 3 \alpha & L_{\mathrm{m}} \cdot \cos 4 \alpha \\
L_{\mathrm{m}} \cdot \cos \alpha & L_{\mathrm{m}} \cdot \cos 2 \alpha & L_{\mathrm{m}} \cdot \cos 3 \alpha
\end{array} \ldots\right. \\
& L_{\mathrm{m}} \cdot \cos 3 \alpha \quad L_{\mathrm{m}} \cdot \cos 4 \alpha \quad L_{\mathrm{m}} \cdot \cos 5 \alpha \\
& L_{\mathrm{m}} \cdot \cos 2 \alpha \quad L_{\mathrm{m}} \cdot \cos 3 \alpha \quad L_{\mathrm{m}} \cdot \cos 4 \alpha \\
& L_{\mathrm{m}} \cdot \cos \alpha \quad L_{\mathrm{m}} \cdot \cos 2 \alpha \quad L_{\mathrm{m}} \cdot \cos 3 \alpha
\end{aligned}
$$

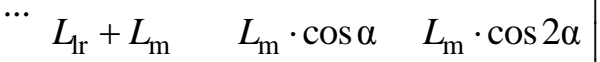

$$
\begin{aligned}
& L_{\mathrm{m}} \cdot \cos 5 \alpha \quad L_{\mathrm{lr}}+L_{\mathrm{m}} \quad L_{\mathrm{m}} \cdot \cos \alpha \\
& L_{\mathrm{m}} \cdot \cos 4 \alpha \quad L_{\mathrm{m}} \cdot \cos 5 \alpha \quad L_{\mathrm{lr}}+L_{\mathrm{m}}
\end{aligned}
$$


Abipusis induktyvumas tarp statoriaus ir rotoriaus $L_{\mathrm{sr}}$ (2.11 formulè) yra kintantis - jis priklauso nuo kampo tarp statoriaus ir rotoriaus apvijų. Nejudamo statoriaus atžvilgiu, šis kampas yra lygus rotoriaus posūkio kampui $\theta_{\mathrm{r}}(t) . L_{\mathrm{sr}}$ kaip ir ankstesnès matricos turi 36 narius:

$$
\begin{aligned}
& L_{\mathrm{sr}}\left(\theta_{\mathrm{r}}\right)=L_{\mathrm{m}}\left[\begin{array}{ccc}
\cos \left(\theta_{\mathrm{r}}(t)\right) & \cos \left(\theta_{\mathrm{r}}(t)+\alpha\right) & \cos \left(\theta_{\mathrm{r}}(t)+2 \alpha\right) \\
\cos \left(\theta_{\mathrm{r}}(t)+5 \alpha\right) & \cos \left(\theta_{\mathrm{r}}(t)\right) & \cos \left(\theta_{\mathrm{r}}(t)+\alpha\right) \\
\cos \left(\theta_{\mathrm{r}}(t)+4 \alpha\right) & \cos \left(\theta_{\mathrm{r}}(t)+5 \alpha\right) & \cos \left(\theta_{\mathrm{r}}(t)\right) \\
\cos \left(\theta_{\mathrm{r}}(t)+3 \alpha\right) & \cos \left(\theta_{\mathrm{r}}(t)+4 \alpha\right) & \cos \left(\theta_{\mathrm{r}}(t)+5 \alpha\right) \\
\cos \left(\theta_{\mathrm{r}}(t)+2 \alpha\right) & \cos \left(\theta_{\mathrm{r}}(t)+3 \alpha\right) & \cos \left(\theta_{\mathrm{r}}(t)+4 \alpha\right) \\
\cos \left(\theta_{\mathrm{r}}(t)+\alpha\right) & \cos \left(\theta_{\mathrm{r}}(t)+2 \alpha\right) & \cos \left(\theta_{\mathrm{r}}(t)+3 \alpha\right)
\end{array} \ldots\right. \\
& \cos \left(\theta_{\mathrm{r}}(t)+3 \alpha\right) \quad \cos \left(\theta_{\mathrm{r}}(t)+4 \alpha\right) \quad \cos \left(\theta_{\mathrm{r}}(t)+5 \alpha\right) \\
& \cos \left(\theta_{\mathrm{r}}(t)+2 \alpha\right) \quad \cos \left(\theta_{\mathrm{r}}(t)+3 \alpha\right) \quad \cos \left(\theta_{\mathrm{r}}(t)+4 \alpha\right) \\
& \cos \left(\theta_{\mathrm{r}}(t)+\alpha\right) \quad \cos \left(\theta_{\mathrm{r}}(t)+2 \alpha\right) \quad \cos \left(\theta_{\mathrm{r}}(t)+3 \alpha\right) \\
& \begin{array}{llll}
\cdots & \cos \left(\theta_{\mathrm{r}}(t)\right) & \cos \left(\theta_{\mathrm{r}}(t)+\alpha\right) & \cos \left(\theta_{\mathrm{r}}(t)+2 \alpha\right)
\end{array} . \\
& \cos \left(\theta_{\mathrm{r}}(t)+5 \alpha\right) \quad \cos \left(\theta_{\mathrm{r}}(t)\right) \quad \cos \left(\theta_{\mathrm{r}}(t)+\alpha\right) \\
& \cos \left(\theta_{\mathrm{r}}(t)+4 \alpha\right) \quad \cos \left(\theta_{\mathrm{r}}(t)+5 \alpha\right) \quad \cos \left(\theta_{\mathrm{r}}(t)\right)
\end{aligned}
$$

Formulëje 2.12 naudojamas induktyvumas tarp rotoriaus ir statoriaus $L_{\mathrm{rs}}$ yra transponuota matrica induktyvumo $L_{\mathrm{sr}}$ :

$$
L_{\mathrm{rs}}\left(\theta_{\mathrm{r}}(t)\right)=L_{\mathrm{sr}}^{\mathrm{T}}\left(\theta_{\mathrm{r}}(t)\right) .
$$

Induktyvumų išraiškos (formulès 2.13-2.16) yra naudojamos srovių skaičiavimuose formulèse 2.11 ir 2.12 .

Elektromagnetinio rotoriaus sukimo momento išraiška:

$$
M_{\mathrm{em}}(t)=i_{\mathrm{s}}^{\mathrm{T}}(t) \frac{\mathrm{d} L_{\mathrm{sr}}\left(\theta_{\mathrm{r}}\right)}{\mathrm{d} \theta_{\mathrm{r}}(t)} \cdot i_{\mathrm{r}}(t)
$$

Elektromagnetinis sukimo momentas ir rotoriaus sukimosi greitis yra vienmačiai skaliariniai dydžiai.

Daugiafazio netransformuoto matematinio modelio privalumai yra aiškumas ir tinkamumas modifikacijai. Jo trūkumas - didesnis skaičiavimų kiekis nei modelių dvifazèse koordinačių sistemose.

Vertinant paskutinị rodiklị, tai yra spartą, atliktas imitacijų atlikimo trukmės tyrimas. 2.1 paveiksle pateiktas modelis lygintas su 2.2 paveiksle pateiktais modeliais dvifazèse koordinačiu sistemose. Juose formuojamos maitinimo įtampos yra transformuojamos prieš atliekant pagrindinius dinamikos skaičiavimus. 


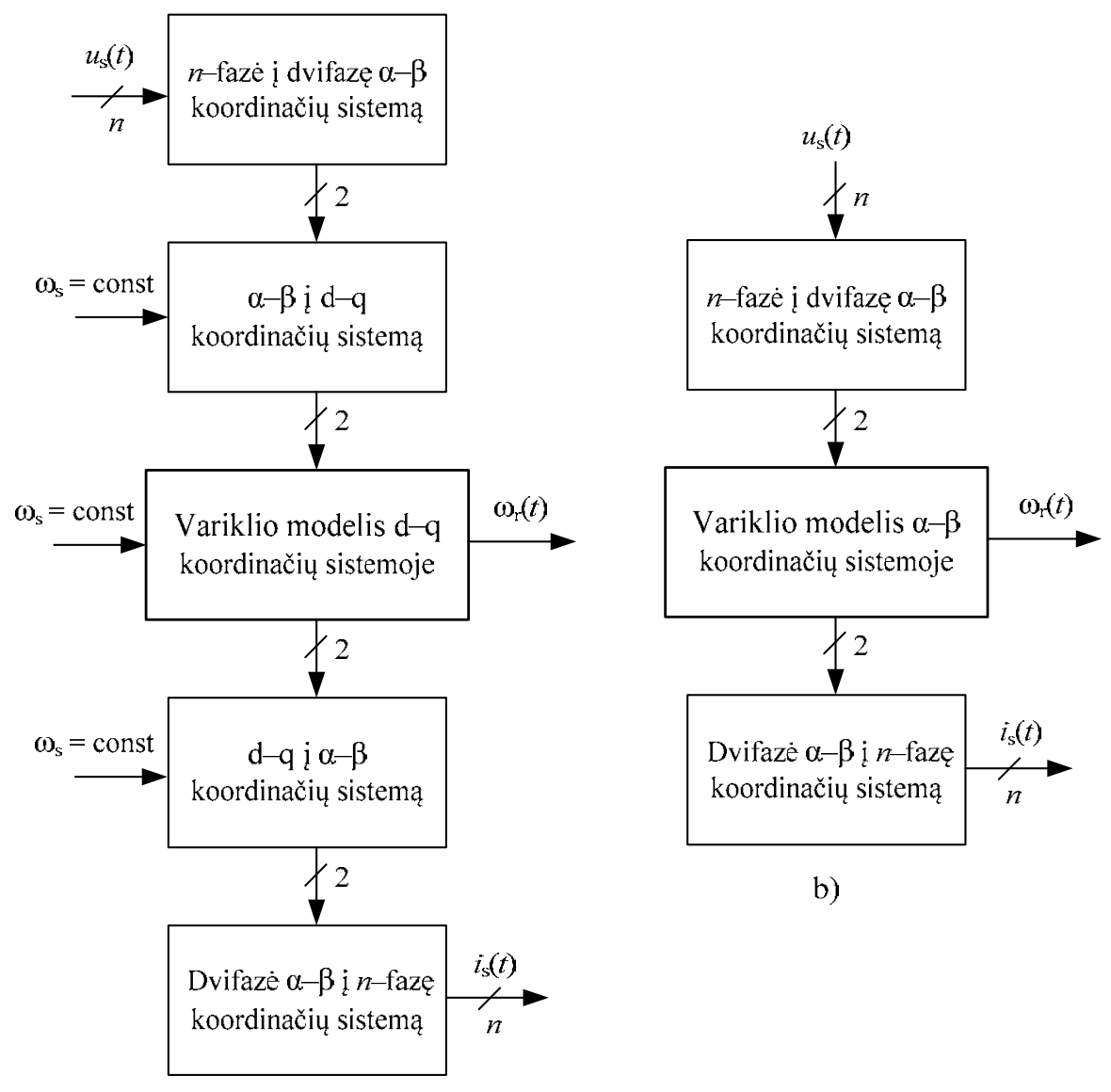

a)

2.2 pav. Daugiafazio asinchroninio variklio imitacinių modelių dvifazėse koordinačių sistemose funkcinės schemos: a) variklio modelio $\mathrm{d}-\mathrm{q}$ koordinačių sistemoje; b) variklio modelio $\alpha-\beta$ koordinačių sistemose Fig. 2.2. Functional block diagrams of multi-phase induction machine computer models in two-dimensional reference frames: a) machine model in $d$-q reference frame; b) machine model in $\alpha-\beta$ reference frame

Tipinis bandymas su variklių modeliais yra jų paleidimo laikinių charakteristiku gavimas. Vienodomis sąlygomis atliekant vienodą skaičiavimų kiekị ir validuojant rezultatų sutapimą naudojant Matlab Simulink programinę įrangą buvo ištirtos imitacijų trukmès. Jos pateiktos 2.1 lentelëje. 
2.1 lentelè. Imitacinių šešiafazio varikio modelių sparta

Table 2.1. Speed of computer models of six-phase induction machine

\begin{tabular}{|l|l|}
\hline Imitacinis modelis & Imitacijos trukmè, s \\
\hline Šešiafazè koordinačių sistema & $5,96 \pm 0,116$ \\
\hline $\begin{array}{l}\text { Dvifazė koordinačių sistema nejudama } \\
\text { statoriaus atžvilgiu }\end{array}$ & $0,390 \pm 0,025$ \\
\hline $\begin{array}{l}\text { Dvifazė koordinačių sistema sinchroninio } \\
\text { greičio atžvilgiu }\end{array}$ & $0,418 \pm 0,066$ \\
\hline
\end{tabular}

Dvifazių koordinačių sistemų imitaciniais modeliais atliekami skaičiavimai trunka tik 7 \% laiko skiriamo siūlomam modeliui, o gautų verčių skirtumas yra tik apvalinimo ịvedamos paklaidos. Spartos skirtumas yra labai svarbus, jei modeliai naudojami tiksliai paieškinei variklio parametrų identifikacijai, kur imitacijų ciklų skaičius yra labai didelis, arba valdyme realiuoju laiku, kur išmatuoti dydžiai nuolat lyginami su imitaciniais.

2.1 lentelèje galima pastebėti, kad nejudamos statoriaus atžvilgiu koordinačių sistemos modelis yra spartesnis už modeli sistemos nejudamos sinchroninio greičio atžvilgiu. Pastaruoju atveju reikia atlikti dydžių transformaciją i tarpinę $\alpha-\beta$ koordinačių sistemą. Šis skirtumas aiškiai matomas 2.2 paveiksle.

Sinchroniniu greičiu besisukanti koordinačių sistema (2.2 pav. a) buvo labai plačiai taikoma trifazių variklių tyrimams, kol kompiuterinè skaičiavimų technika buvo nepajėgi apdoroti didelių informacijos kiekių. d-q koordinačių sistema reiškia, kad signalai aprašomi amplitude ir faze. Supaprastinus tyrimo užduotị laikoma, kad maitinimo ịtampų dažnis yra pastovus ir sutampa su sinchroniniu greičiu. Tada ị variklio modelị užtenka pateikti maitinimo ịtampų suminio vektoriaus amplitudę. Tai yra vienas vienmatis skaliarinis dydis. Jei tiriama atvira sistema, šis dydis gali būti konstanta, o fazė prilyginama nuliui. Greičio ir sukimo momento laikinių charakteristikų radimas tokiu atveju tampa įmanomas be kompiuterinès technikos.

Naudojant šiuolaikinius kompiuterius tokių problemų spręsti nereikia ir modelio universalumas ir sparta tampa svarbesniais rodikliais. Vietoje dvifazės sinchroniniu greičiu besisukančios koordinačių sistemos yra geriau rinktis vieną iš kitų dviejų modelių, išvardintų 2.1 lentelëje.

Siūlomas šešiafazis modelis gali imituoti bet kokių amplitudžių ir dažnių maitinimo ịtampų poveikị išèjimo dydžiams. Tiriant šiuolaikines elektros pavaras naudinga turèti modelį, kuris pateikia informaciją apie sistemos būseną netransformuotais kintamaisiais. Elektros pavarose svarbu ịvertinti ne tik sukimo momentą ir greitį, bet tuo pačiu ir statoriaus akimirkines sroves, magnetinị srautą oro tarpe. 
Iprasta naudoti specializuotas matematinio modeliavimo programas tokias kaip Matlab, nes jose prieinamos plačios bibliotekos ịvairiems technikos komponentams imituoti. Šiuo atveju reikiami komponentai yra valdikliai, keitikliai, elektros varikliai. Matlab siūlomi sprendimai yra Simulink programinio paketo bibliotekose.

Trifazės pavaros modeliavimas yra labai paprastas, nes prieinami tokie elektrotechnikos ir elektronikos komponentai, kaip trifaziai inverteriai, IPM generatoriais ir įvairių konstrukcijų elektros varikliai. Tuo pačiu galima rasti ir pavyzdinių elektros pavarų modelių. Tačiau daugiafazès pavaros nėra standartiniai komponentai. Nėra prieinamo nei vieno reikiamo standartinio šešiafazio komponento.

Funkcinè dažninès pavaros, kuri realizuota panaudojant trifazę galios dali, schema pavaizduota 2.3 paveiksle.

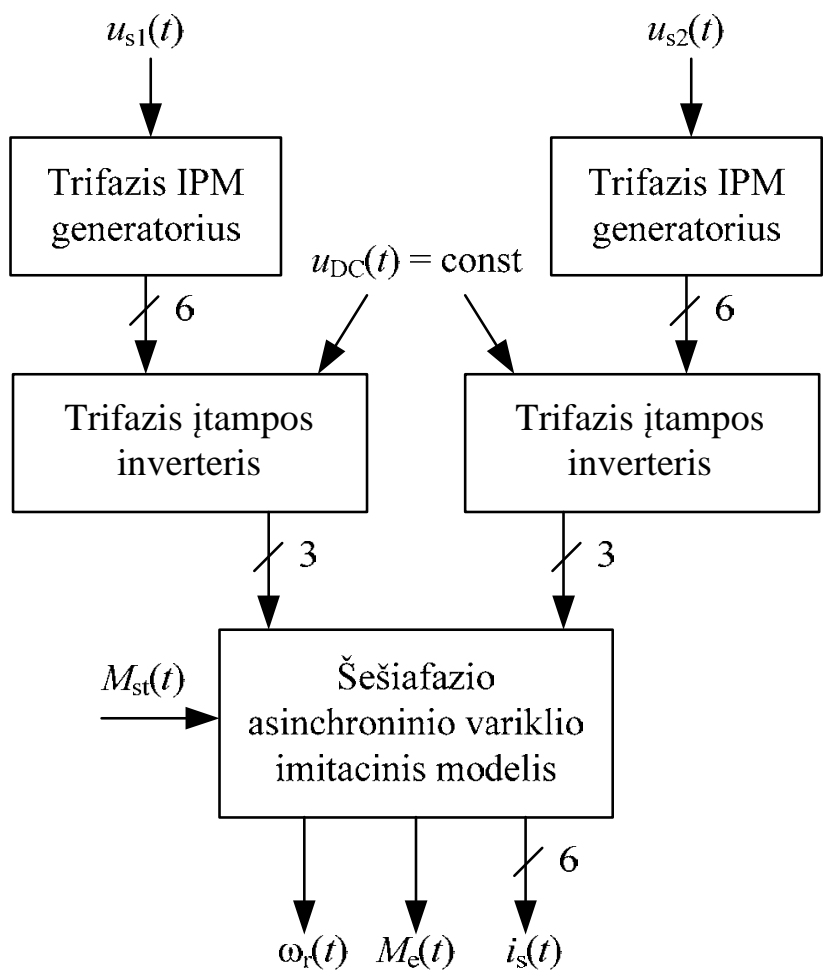

2.3 pav. Šešiafazės dažninės asinchroninės pavaros funkcinė schema

Fig. 2.3. Functional block diagram of six-phase induction frequency drive 
Dèl simetrinio šešiafazio variklio panašumo ị trifazị variklį, pavyko sėkmingai panaudoti trifazius matematinio modeliavimo komponentus dažninei pavarai sudaryti (2.3 pav.). Atlikus šešių fazių atskyrimą ị du trifazius rinkinius, panaudoti aukščiau Simulink bibliotekos paminèti komponentai, išskyrus variklio modeli, kuris nagrinètas poskyrio pradžioje.

IPM generatoriai formuoja po šešis inverterio raktams skirtus signalus - tris sinusoides su 120 laipsnių faziniais kampais. Vertinant simetrinį šešiafazio statoriaus apvijų išdėstymą - 60 elektrinių laipsnių tarp gretimų apvijų - išskirti du įtampų fazès dedamųjų $u_{\mathrm{qs}}(t)$ rinkiniai:

$$
\begin{gathered}
u_{\mathrm{s} 1}(t)=\frac{U(t)}{u_{\mathrm{DC}}(t)} \cdot\left[\begin{array}{lll}
\cos (\omega t) & \cos \left(\omega t+120^{\circ}\right) & \cos \left(\omega t+240^{\circ}\right)
\end{array}\right]^{\mathrm{T}}, \\
u_{\mathrm{s} 2}(t)=\frac{U(t)}{u_{\mathrm{DC}}(t)} \cdot\left[\begin{array}{lll}
\cos \left(\omega t+60^{\circ}\right) & \cos \left(\omega t+180^{\circ}\right) & \cos \left(\omega t+300^{\circ}\right)
\end{array}\right]^{\mathrm{T}} .
\end{gathered}
$$

Tarp statoriaus įtampų rinkinių (2.18 ir 2.19 formulès) yra 60 elektrinių laipsnių skirtumas. Be to, visų fazių įtampų amplitudès yra lygios - tai simetrinių maitinimo įtampų atvejis. Svarbu pastebėti, kad ịtampos amplitudè yra santykinis dydis, kuris negali viršyti nuolatinès įtampos tiekiamos inverteriams.

Trifaziai įtampos inverteriai formuoja nuolatinès ịtampos $u_{\mathrm{DC}}(t)$ dydžio impulsus. Kadangi tyrimams naudojamas mažos galios variklis, maitinamas iš buitinio elektros tinklo, ịtampos kritimas nuolatinės srovės grandyje nèra vertinamas.

Plačiausiai taikomas asinchroninių pavarų valdymo būdas yra skaliarinis dažninis $U / f$ metodas:

$$
\frac{U(t)}{f(t)}=\text { const, }
$$

čia $U(t)$ - moduliuojamos ịtampos amplitudè, $f(t)$ - fazinis dažnis.

Varikliai projektuojami darbui nominaliajai maitinimo ịtampa ir jos nominaliajam dažniui. Tokiomis sąlygomis elektriniai nuostoliai yra patys mažiausi. Variklio greičiui reguliuoti, tenka keisti maitinimo įtampos parametrus. Būtent U/f greičio valdymo būdas užtikrina darbą su mažiausiais elektriniais nuostoliais plačiame greičių diapazone.

2.18 ir 2.19 formulèse pateiktas dažnis $\omega(t)$ yra tas pats fazinis dažnis $f(t)$ išreikštas kitais matavimo vienetais - radianais per sekundę. Šis dažnis įtakoja greití, o įtampos amplitudè - magnetolaidžio įsisotinimą.

Dèl tiesioginès maitinimo įtampos priklausomybès nuo fazinio dažnio, šį valdymo būdą paprasčiau suprasti, kaip sistemą su vienu valdymo signalu - faziniu dažniu. Šis dydis yra tiesiogiai proporcingas sinchroniniam greičiui. U/f valdymo būdo be grịžtamojo ryšio funkcinè schema pateikta 2.4 paveiksle. 


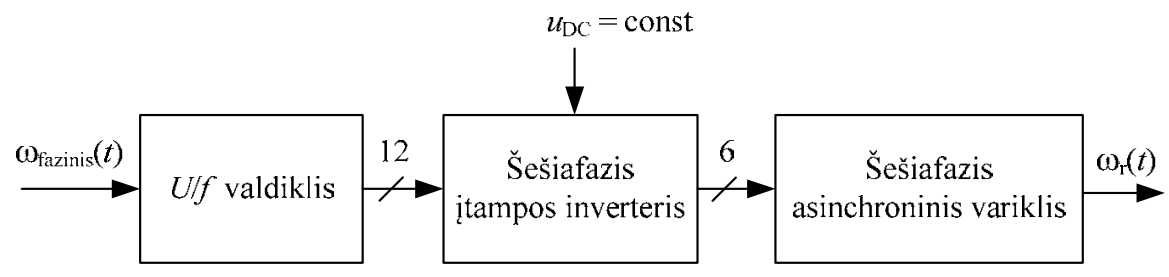

2.4 pav. Atviros $U / f$ valdymo sistemos funkcinè schema

Fig. 2.4. Functional block diagram of $U / f$ control open-loop system

Imituojamas procesas yra pavaros paleidimas be pakrovos, vèliau darbas apkrovus pastovia apkrova ir, galiausiai, stabdymas. Taikomas sklandusis paleidimas (angl. soft start) ir stabdymas, kai ribojamas pagreitis palaipsniui didinat fazinị dažnį nuo nulio iki užduotos vertės. Imituojamą procesą galima suskirstyti ị šiuos penkis etapus:

1. sklandusis paleidimas - laiko momentu $t=0 \mathrm{~s}$ užduotas pagreitis yra $100 \mathrm{rad} / \mathrm{s}^{2}$, kol pasiekiamas užduotas variklio greitis $50 \mathrm{rad} / \mathrm{s}$;

2. tuščioji veika - po paleidimo iki laiko momento $t=1,5 \mathrm{~s}$;

3. apkrova - nuo laiko momento $t=1,5 \mathrm{~s}$ iki $t=4,5 \mathrm{~s}$ imituojamas statinis apkrovos momentas $-75 \mathrm{~N} \cdot \mathrm{m}$;

4. tuščioji veika - po apkrovos iki laiko momento $t=5,5 \mathrm{~s}$;

5. stabdymas - laiko momentu $t=5,5 \mathrm{~s}$ užduotas pagreitis yra minus $100 \mathrm{rad} / \mathrm{s}^{2}$, kol variklis sustoja.

Imituojamas bandymas su šiais variklio parametrais:

2.2 lentelè. Imituoto asinchroninio variklio parametrai

Table 2.2. Parameters of simulated induction motor

\begin{tabular}{|l|l|l|l|l|l|l|l|l|}
\hline$U, \mathrm{~V}$ & $f, \mathrm{~Hz}$ & $J, \mathrm{~kg} \cdot \mathrm{m}^{2}$ & $\mathrm{p}$ & $R_{\mathrm{s}}, \Omega$ & $R_{\mathrm{r}}, \Omega$ & $L_{\mathrm{ls}}, \mathrm{mH}$ & $L_{\mathrm{ll}}, \mathrm{mH}$ & $L_{\mathrm{m}}, \mathrm{mH}$ \\
\hline 400 & 50 & 0,0331 & 2 & 1,41 & 1,395 & 2,92 & 5,839 & 0,1722 \\
\hline
\end{tabular}

2.5 paveiksle pateiktas pavaros su atvira valdymo sistema rotoriaus sukimosi greičio pereinamasis vyksmas. Punktyrine linija yra pažymètas užduotas greitis minkštas paleidimas iki $50 \mathrm{rad} / \mathrm{s}$ greičio ir sklandusis stabdymas nuo laiko momento 5,5 s. Apkrovus varikli laiko momentu 1,5 s, vyksta nekompensuojamas greičio krytis 9 procentais. Šio pereinamojo vyksmo metu, greitis nusistovi per $0,26 \mathrm{~s}$ ir perreguliavimas siekia $134 \%$. 


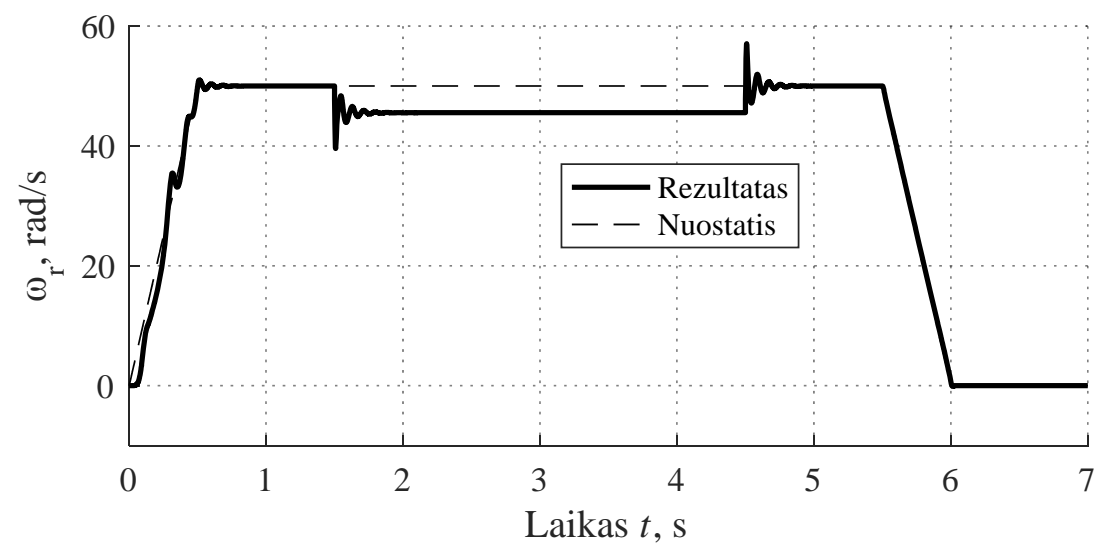

2.5 pav. Skaliarinės $U / f$ valdymo pavaros imitacinis rotoriaus sukimosi greičio pereinamasis vyksmas

Fig. 2.5. Simulated transient process of scalar $U / f$ controlled drive rotor speed

2.6 paveiksle matomas elektromagnetinio sukimo momento pereinamasis vyksmas, kuriame stebimi švytavimai sklandžiojo paleidimo metu proceso pradžioje. Veikiant apkrovai elektromagnetinis sukimo momentas nusistovi ties apkrovos momento verte. Stabdymo metu stebima neigiama sukimo momento vertè.

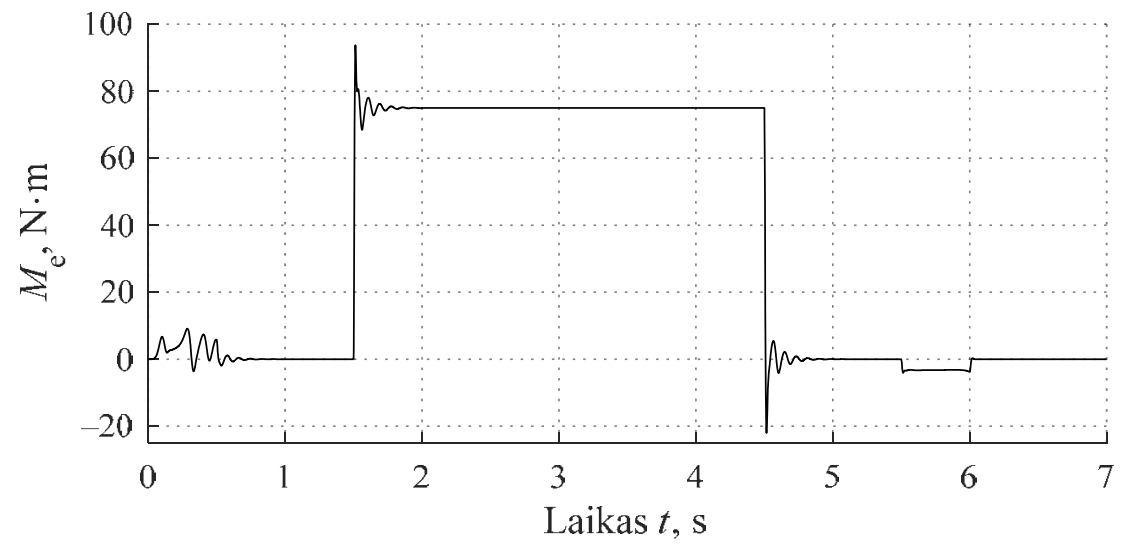

2.6 pav. Skaliarinès $U / f$ valdymo pavaros imitacinis elektromagnetinio sukimo momento pereinamasis vyksmas

Fig. 2.6. Simulated transient process of scalar $U / f$ controlled drive electromagnetic torque 


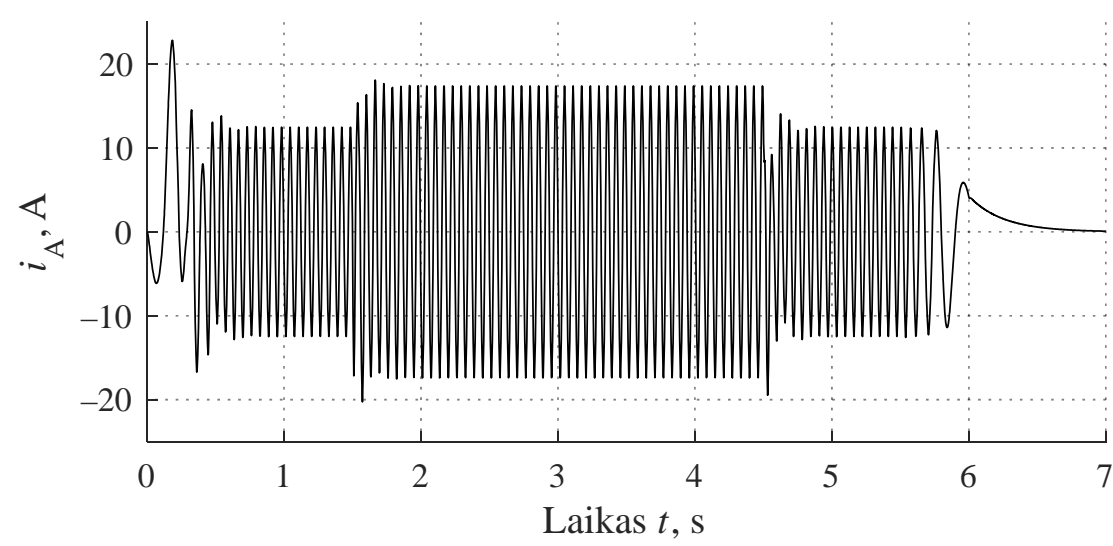

2.7 pav. Skaliarinès $U / f$ valdymo pavaros imitacinis statoriaus fazinès A srovès pereinamasis vyksmas

Fig. 2.7. Simulated transient process of scalar $U / f$ controlled drive stator phase A current

Sklandusis paleidimas taikomas siekiant apriboti statoriaus srovė pavaros paleidimo metu. 2.7 paveiksle stebimas vienos statoriaus fazinès srovės pikas iki 22,8 A, kuris viršija tuščiosios veikos vertę 82 \%. Priklausomai nuo variklio techninių parametrų, sklandžiojo paleidimo konstanta (maitinimo įtampos pokytis per laiko vienetą) turi būti koreguojama.

Skaliarinis valdymas dažnai naudojamas pavarose, kuriose nèra keliami aukšti reikalavimai tikslumui ir greitaveikai, t. y. naudojamas siurbliams, ventiliatoriams ir pan.

\subsection{Vektorinis šešiafazių pavarų valdymas}

Nors tiesioginis momento valdymas (TMV) pristatytas prieš 30 metu (1986 m.), jis naudojamas pavarų valdyme dèl didelès greitaveikos ir tikslaus momento valdymo nenaudojant sudètingų algoritmų. TMV sistema turi aukštus matavimo tikslumo reikalavimus, nes realiu laiku skaičiuojami sukimo momento, statoriaus srauto amplitudès ir srauto vektoriaus kampo signalai. Tačiau pati valdymo struktūra nèra labai sudètinga. Tai vienas iš pagrindinių šio valdymo privalumų (Sheidaei et al. 2007).

Šis valdymo metodas iš esmès skiriasi nuo dažninės pavaros struktūros, nes leidžia valdikliu tiesiogiai valdyti galios dalies raktus nenaudojant IPM moduliatoriaus. 
Tinkamai valdant srautą ir momentą, tiesioginis momento valdymas tampa atsparus išoriniams trikdžiams ir variklio parametrų nuokrypoms. Tačiau esant nusistovejjusiam darbo režimui susidaro pastebimi srauto ir momento švytavimai, ypač taikant histerezės kilpas žemų greičių srityje (Sheidaei et al. 2007).

Statoriaus srautas ir kuriamas momentas skaičiuojami ịvertinant tik statoriaus sroves, įtampas ir apvijų aktyviąją varžą. Pirmiausiai, randamos akimirkinių srovių ir įtampų projekcijos ị statoriaus atžvilgiu nejudamą koordinačių plokštumą taikant Park'o transformaciją. Trifazio variklio atveju, jos yra standartinès:

$$
\begin{aligned}
& \left\{\begin{array}{l}
i_{\alpha \mathrm{s}}(t)=\frac{2}{3} i_{\mathrm{A}}(t)-\frac{1}{3} i_{\mathrm{B}}(t)-\frac{1}{3} i_{\mathrm{C}}(t), \\
i_{\beta \mathrm{S}}(t)=-\frac{1}{\sqrt{3}} i_{\mathrm{B}}(t)+\frac{1}{\sqrt{3}} i_{\mathrm{C}}(t),
\end{array}\right. \\
& \left\{\begin{array}{l}
u_{\alpha \mathrm{s}}(t)=\frac{2}{3} u_{\mathrm{A}}(t)-\frac{1}{3} u_{\mathrm{B}}(t)-\frac{1}{3} u_{\mathrm{C}}(t), \\
u_{\beta \mathrm{s}}(t)=-\frac{1}{\sqrt{3}} u_{\mathrm{B}}(t)+\frac{1}{\sqrt{3}} u_{\mathrm{C}}(t) .
\end{array}\right.
\end{aligned}
$$

Daugiafazės pavaros atveju reikia taikyti asinchroninio variklio matematinio modelio įtampų lygtis pateiktas 1.4 formulejje. Pabrèžiama, kad šios lygtys galioja varikliui su izoliuotu nuliniu statoriaus tašku. Atitinkamai statoriaus srovių projekcijos yra tokios:

$$
\begin{aligned}
& {\left[\begin{array}{l}
i_{\alpha \mathrm{s}}(t) \\
i_{\beta \mathrm{S}}(t)
\end{array}\right]=\sqrt{\frac{1}{3}} \cdot\left[\begin{array}{lll}
\cos (0) & \cos (\alpha) & \cos (2 \alpha) \\
\sin (0) & \sin (\alpha) & \sin (2 \alpha)
\end{array} \cdots\right.}
\end{aligned}
$$

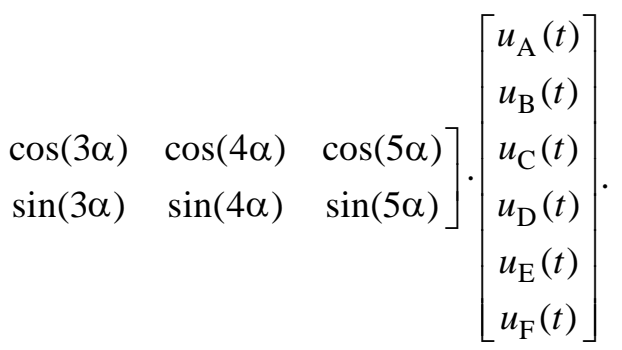

TMV metodui reikia tik vieno variklio parametro - statoriaus aktyviosios varžos $R_{\mathrm{s}}$. Norint gauti gerus pavaros valdymo rezultatus reikia žinoti tikslią statoriaus varžos vertę, ypač mažų greičių zonoje (Draou et al. 2010).

Taikant idealizuotą matematinị variklio modelị, ši varža yra pastovus dydis, tačiau realiomis sąlygomis tai yra kintamas dydis. To priežastis yra šiluminis poveikis. Žinant fizikines dèsnius tokị efektą galima įdiegti, tačiau netikslinga. 
Šiame skyriuje siekiama pritaikyti patị tiksliausią trifazių asinchroninių variklių greičio ir sukimo momento valdymo metodą daugiafazėms pavaroms. Nèra spendžiamos tik eksperimentiniuose bandymuose pasireiškiančios techninès problemos.

Statoriaus magnetinio srauto dedamosios $\Psi_{\alpha s}(t)$ ir $\Psi_{\beta s}(t)$ gaunamos iš variklio matematinio modelio $\alpha-\beta$ koordinačių sistemoje. Reikiamos išraiškos pateiktos pirmojo skyriaus 1.6 formulèje. Atitinkamai elektromagnetinio sukimo momento išraiška pateiktas 1.14 formulèje.

TMV palaiko užduotą magnetinio srauto amplitudinę vertę ir komutuoja inverterio raktus pagal magnetinio srauto vektoriaus kampą. Šios vertės randamos nesudètingai, tačiau realiose sistemoje sąlyginai daug resursų reikalaujančiomis matematinėmis operacijomis:

$$
\begin{gathered}
\left|\Psi_{\mathrm{S}}\right|(t)=\sqrt{\Psi_{\alpha \mathrm{S}}^{2}(t)+\Psi_{\beta \mathrm{S}}^{2}(t)}, \\
\angle \Psi_{\mathrm{S}}(t)=\operatorname{arctg}\left(\frac{\Psi_{\beta \mathrm{s}}(t)}{\Psi_{\alpha \mathrm{S}}(t)}\right) .
\end{gathered}
$$

Dèl patogumo magnetinio srauto kampas $\angle \Psi_{\mathrm{s}}(t)$ bus žymimas $\varphi(t)$.

Šie srauto, momento ir fazès skaičiavimai skirti būtinų TMV valdymo vidinių kintamujjų radimui (Metidji et al. 2012).

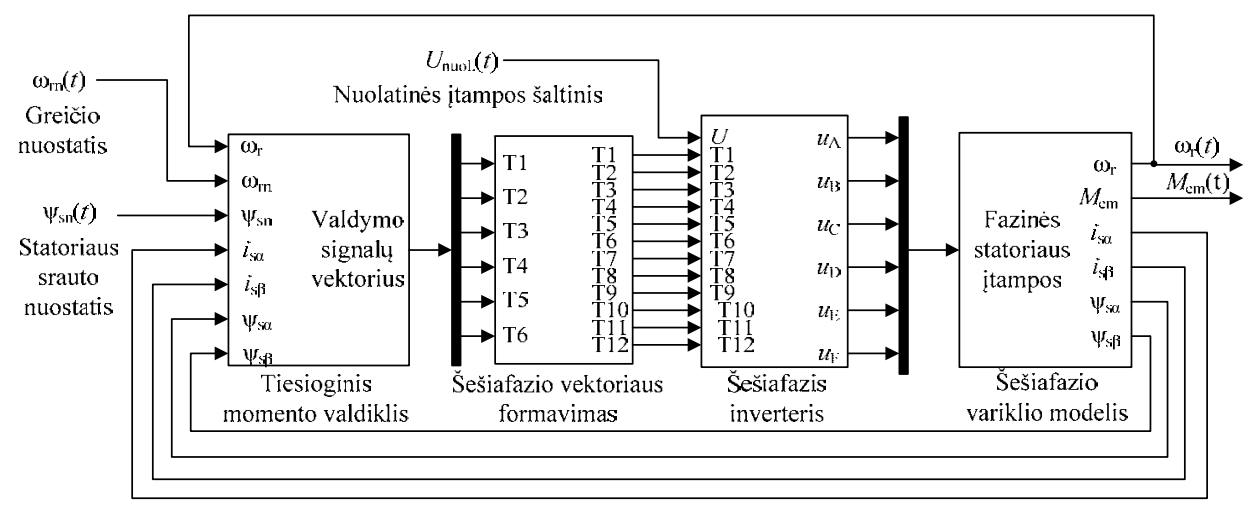

2.8 pav. Šešiafazės pavaros su tiesioginiu momento valdymu imitacinis modelis

Fig. 2.8. Computer model of six-phase drive with direct torque control

Sudarytas kompiuterinis pavaros su vektoriniu valdymu modelis, pateiktas 2.8 paveiksle. Naudojamas nekoreguotas tiesioginis momento valdiklis iš Matlab/Simulink bibliotekos, kurị sudaro greičio valdiklio blokas, sukimo momento, 
srauto ir kampo nustatymo blokas, srauto ir sukimo momento histerezės kilpų blokas, srauto sektoriaus nustatymo blokas ir vektorių parinkimo lentelès blokas.

Vektoriaus formavimo blokas, esantis 2.8 paveiksle pateiktame pavaros kompiuteriniame modelyje, yra reikalingas tik šešiafazio keitiklio imitavimui. Trifazio keitiklio atveju, šio bloko nèra ir vektoriaus valdymo signalai patenka tiesiai ị inverterį: šeši signalai iš tiesioginio momento valdiklio šešiems inverterio raktams.

2.9 paveiksle pateikta vektoriu diagrama, nusakanti kokius vektorius formuoja sudarytas kompiuterinis tiesioginio momento valdymo pavaros modelis. Paprasčiausiu atveju, vektorių, kuriuos formuoja šešiafazis keitiklis kryptys sutampa su trifazio. Trifaziame variklyje egzistuotų tik A, C ir E fazès, tačiau keičiant poliškumą gaunami iš viso 6 vektoriai, 2.9 paveiksle žymimi $U_{0}-U_{7}$.

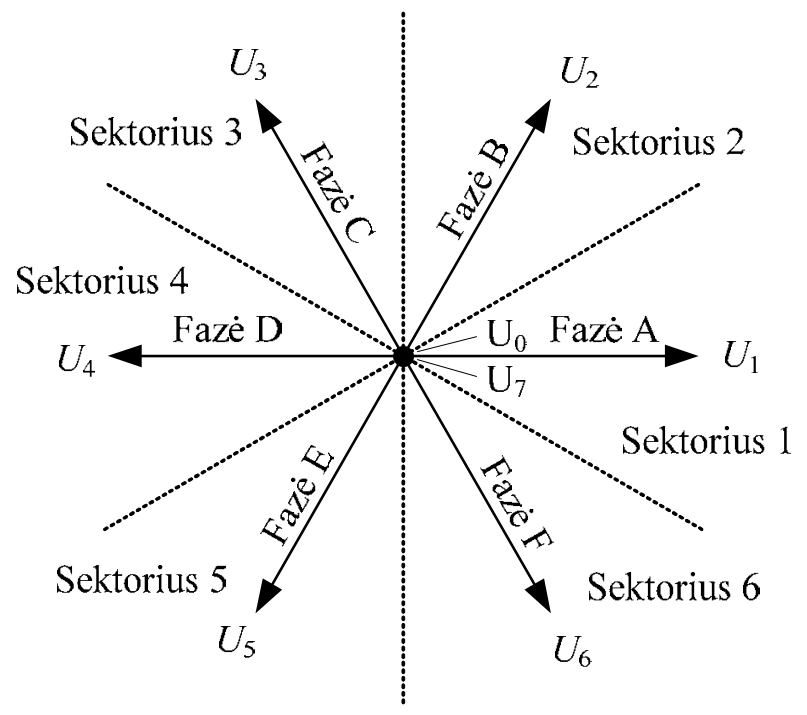

2.9 pav. İtampos vektorių diagrama

Fig. 2.9. Voltage vector diagram

$n$-fazès pavaros atveju įtampų vektorių kiekis yra $2^{n}$, tai šešiafazès atveju 64 kombinacijos, vietoje 8. Uždavinys tampa labai sudètingas, jei ieškoma optimalių maitinimo ịtampų vektorių. Siekiant gauti pirmajị veikiantị variantą, su kuriuo būtų galima lyginti kitus sprendinius, pasirinktas ilgiausių vektorių metodas.

Vertinant 2.9 paveiksle pateiktą vektorių diagramą, galima daryti prielaidą, kad statoriaus apvijų poros su 180 laipsnių elektriniu kampu gali kurti vieną dvigubo ilgio vektorių. Jei fazè A turès teigiamą poliškumą, o fazė D - neigiamą, tai jų kryptys sutaps. Taip virtualiai sumažinus vektorių skaičių iš šešių i tris, gaunama standartinè TMV vektorių diagrama. 
Vektorių formavimo klausimas sprendžiamas praplečiant trifazio inverterio raktų būsenų lentelę. Laikoma, kad raktai sunumeruoti pagal 2.10 paveikslą. Norint suformuoti 2.9 paveiksle pažymètus ịtampų vektorius $U_{0}-U_{7}$, išlaikoma simetrija (2.3 lentelè).

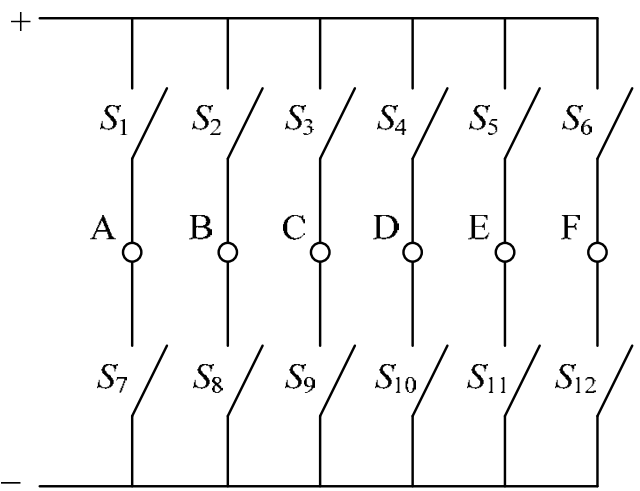

2.10 pav. Idealizuoto šešiafazio inverterio principinė schema

Fig. 2.10. Basic circuit of ideal six-phase inverter

2.3 lentelė. Raktų būsenos maitinimo ịtampos vektoriams formuoti

Table 2.3. Switch states for source voltage vector production

\begin{tabular}{|l|l|}
\hline Itampos vektorius & Raktų būsenų vektorius \\
\hline$U_{0}$ & 000000111111 \\
\hline$U_{1}$ & 110001001110 \\
\hline$U_{2}$ & 111000000111 \\
\hline$U_{3}$ & 011100100011 \\
\hline$U_{4}$ & 001110110001 \\
\hline$U_{5}$ & 000111111000 \\
\hline$U_{6}$ & 100011011100 \\
\hline$U_{7}$ & 111111000000 \\
\hline
\end{tabular}

Tiesioginio momento valdymo sistemos įëjimo signalai yra magnetinio srauto ir sukimo momento paklaidos bei rotoriaus kampinė padètis. Taikant histerezės kilpos reguliatorius, paklaidų signalai vertinami kaip atitinkamai dviejų ir trijų lygių kintamieji. Pagal taip supaprastintus signalus parenkamas statoriaus maitinimo ịtampų vektorius. Visos galimos kombinacijos pateiktos 2.4 lentelèje. 
2.4 lentelè. Tiesioginio momento valdymo įtampos vektorių parinkimo lentelè

Table 2.4. Selection table for direct torque control voltage vectors

\begin{tabular}{|l|l|l|l|l|l|l|l|}
\hline$e_{\Psi}$ & $e_{\mathrm{M}}$ & S. 1 & S. 2 & S. 3 & S. 4 & S. 5 & S. 6 \\
\hline \multirow{4}{*}{+1} & +1 & $U_{2}$ & $U_{3}$ & $U_{4}$ & $U_{5}$ & $U_{6}$ & $U_{1}$ \\
\cline { 2 - 9 } & 0 & $U_{7}$ & $U_{0}$ & $U_{7}$ & $U_{0}$ & $U_{7}$ & $U_{0}$ \\
\cline { 2 - 9 } & -1 & $U_{6}$ & $U_{1}$ & $U_{2}$ & $U_{3}$ & $U_{4}$ & $U_{5}$ \\
\hline \multirow{4}{*}{-1} & +1 & $U_{3}$ & $U_{4}$ & $U_{5}$ & $U_{6}$ & $U_{1}$ & $U_{2}$ \\
\cline { 2 - 9 } & 0 & $U_{0}$ & $U_{7}$ & $U_{0}$ & $U_{7}$ & $U_{0}$ & $U_{7}$ \\
\cline { 2 - 8 } & -1 & $U_{5}$ & $U_{6}$ & $U_{1}$ & $U_{2}$ & $U_{3}$ & $U_{4}$ \\
\hline
\end{tabular}

Šešiafaziame variklyje, tarp kurio gretimų fazių yra 60 elektrinių laipsnių, fazių erdvinès padètys sutampa su pageidaujamais formuoti vektoriais. Tokiu atveju nereikia sudaryti naujos vektorių parinkimo lentelès.

\subsection{Vektorinis šešiafazių pavarų su neraiškiosios logikos reguliatoriais valdymas}

Taikant neraiškiają logiką tiesioginio momento valdymo pagrindas išlieka nepakitęs. Neraiškiosios logikos valdiklis apjungia momento ir srauto histerezių valdiklių ir vektorių parinkimo lentelès funkcijas, todèl funkcinè schema (2.11 pav.) didžiąja dalimi atitinka tipinị tiesioginị momento valdymą.

Statoriaus srautas ir kuriamas momentas valdomi tiesiogiai tinkamai parenkant erdvinius statoriaus ịtampų vektorius, t. y. parenkant inverterio raktų būsenas. Kadangi pasirinktas inverteris turi šešis raktus, neraiškiosios logikos valdiklis taip pat turi šešis išèjimus, kuriuose formuoja signalus kiekvieno rakto valdymui. Šie signalai gali įgyti tik dvi reikšmes -0 ir 1 .

Standartinio ir neraiškiosios logikos valdymų ịejjimo signalai yra statoriaus srauto ir elektromagnetinio momento nuokrypos:

$$
\begin{gathered}
e_{\Psi}(t)=\Psi_{\mathrm{s}, \mathrm{n}}(t)-\Psi_{\mathrm{s}}(t), \\
e_{\mathrm{M}}(t)=M_{\mathrm{e}, \mathrm{n}}(t)-M_{\mathrm{e}}(t),
\end{gathered}
$$

čia $\Psi_{\mathrm{s}, \mathrm{n}}(t)$ - statoriaus magnetinio srauto nuostatis, $\Psi_{\mathrm{s}}(t)$ - apskaičiuota statoriaus magnetinio srauto amplitudè, $M_{\mathrm{e}, \mathrm{n}}(t)$ - sukimo momento nuostatis, $M_{\mathrm{e}}(t)$ - apskaičiuotas elektromagnetinis sukimo momentas. 


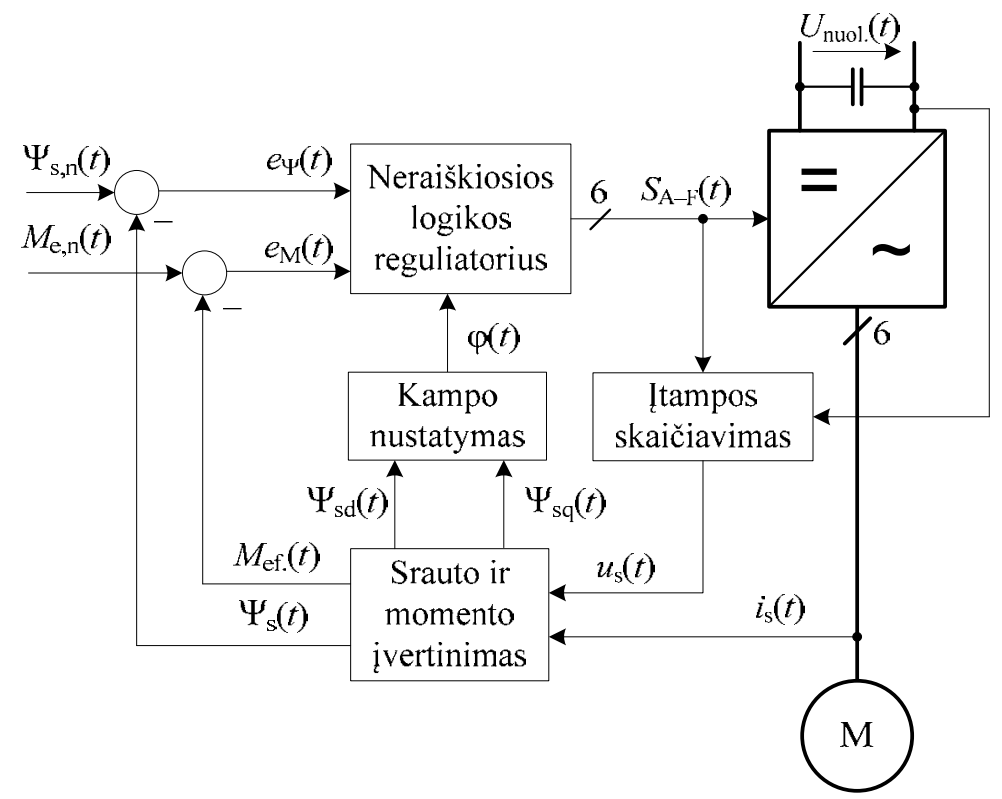

2.11 pav. Tiesioginio momento valdymo su neraiškiosios logikos reguliatoriumi funkcinè schema

Fig. 2.11. Functional block diagram of direct torque fuzzy control

Pagal tipinio TMV vektorių parinkimo lentelę (2.4 lentelè), sudaromos neraiškiosios logikos reguliatoriaus taisyklès. Jos pateiktos 2.5 lentelèje.

2.5 lentelè. Neraiškiosios logikos reguliatoriaus taisyklių rinkinys

Table 2.5. Rules for fuzzy logic controller

\begin{tabular}{|l|l|l|l|l|l|l|l|}
\hline$e_{\Psi}$ & $e_{\mathrm{M}}$ & S. 1 & S. 2 & S. 3 & S. 4 & S. 5 & S. 6 \\
\hline$>>1$ & - & $U_{1}$ & $U_{2}$ & $U_{3}$ & $U_{4}$ & $U_{5}$ & $U_{6}$ \\
\hline \multirow{4}{*}{+1} & +1 & $U_{2}$ & $U_{3}$ & $U_{4}$ & $U_{5}$ & $U_{6}$ & $U_{1}$ \\
\cline { 2 - 9 } & 0 & $U_{7}$ & $U_{0}$ & $U_{7}$ & $U_{0}$ & $U_{7}$ & $U_{0}$ \\
\cline { 2 - 8 } & -1 & $U_{6}$ & $U_{1}$ & $U_{2}$ & $U_{3}$ & $U_{4}$ & $U_{5}$ \\
\hline \multirow{4}{*}{-1} & +1 & $U_{3}$ & $U_{4}$ & $U_{5}$ & $U_{6}$ & $U_{1}$ & $U_{2}$ \\
\cline { 2 - 8 } & 0 & $U_{0}$ & $U_{7}$ & $U_{0}$ & $U_{7}$ & $U_{0}$ & $U_{7}$ \\
\cline { 2 - 8 } & -1 & $U_{5}$ & $U_{6}$ & $U_{1}$ & $U_{2}$ & $U_{3}$ & $U_{4}$ \\
\hline$<-1$ & - & $U_{4}$ & $U_{5}$ & $U_{6}$ & $U_{1}$ & $U_{2}$ & $U_{3}$ \\
\hline
\end{tabular}


Reguliatorius parenka ịtampos vektorius pagal 2.5 lentelèje pateiktas taisykles. Išejjimo signalai priklauso nuo statoriaus srauto nuokrypos, momento nuokrypos ir srauto fazès. +1 atitinka padidèjimą, -1 atitinka sumažejjimą, $>>1-$ ribinị padidejimą, $<<-1$ - ribinį sumažèjimą, 0 - tinkamą vertę. Nuo S.1 iki S.6 tai fazès sektoriaus numeris. Priklausomybès sudarytos aštuoniems ịtampos vektoriams, t. y. trifaziam inverteriui su šešiais raktais. Nuo $U_{0}$ iki $U_{7}-$ visos leidžiamos raktų būsenų kombinacijos.

Neraiškiosios logikos reguliatoriaus sudarymui pasirinktas Mamdani metodas. Jis leidžia formuoti diskretinius išejjimo signalus, todẻl galimas tikslus inverterio valdymo.

Vietoje tipiniame TMV naudojamų histerezės kilpos tipo reguliatorių, neraiškiosios logikos reguliatoriuje įèjimo signalai išreiškiami neraiškiosios logikos lygiais ribose nuo 0 iki 1 . Sudarytos priklausomybių funkcijos pavaizduotos 2.122.14 paveiksluose.

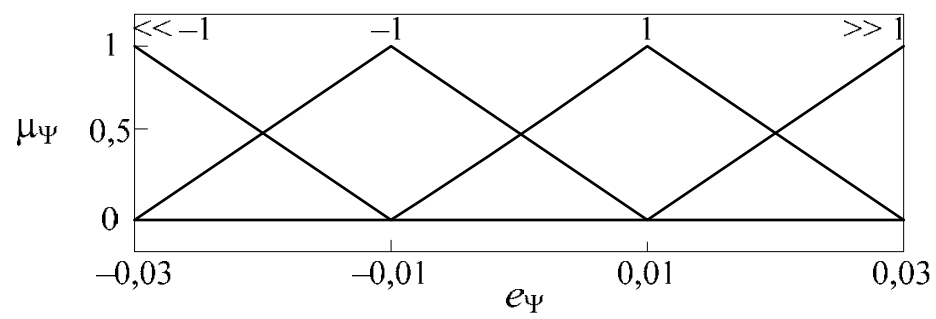

2.12 pav. Statoriaus srauto nuokrypos priklausomybės funkcijos

Fig. 2.12. Membership functions of stator flux deviation

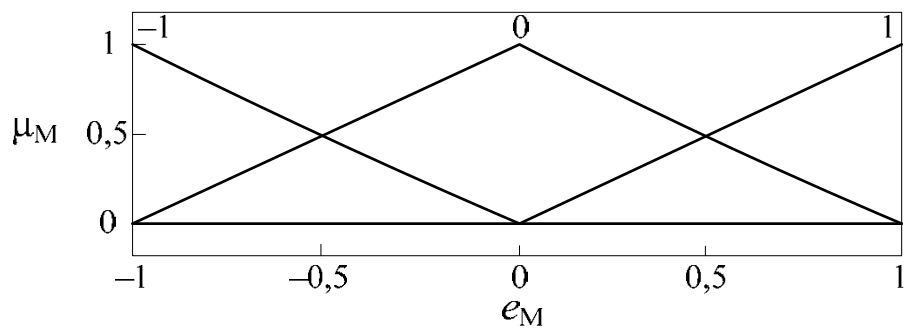

2.13 pav. Sukimo momento nuokrypos priklausomybės funkcijos

Fig. 2.13. Membership functions of torque deviation

2.14 paveiksle matyti, kad fazinis kampas padalijamas i 6 sektorius. Pažymètina, kad ketvirtas sektorius turi 2 priklausomybių funkcijas. Tai būtina, nes fazès 
signalo kinta srityje [-180 180], o sektorius ribojasi su abiem ribomis, t. y. [-180 -120] ir [120 180]. Taip sukuriamas papilomos 8 neraiškiosios logikos valdiklio taisyklès (2.5 lentelè) ir jų skaičius iš 48 tampa 56.

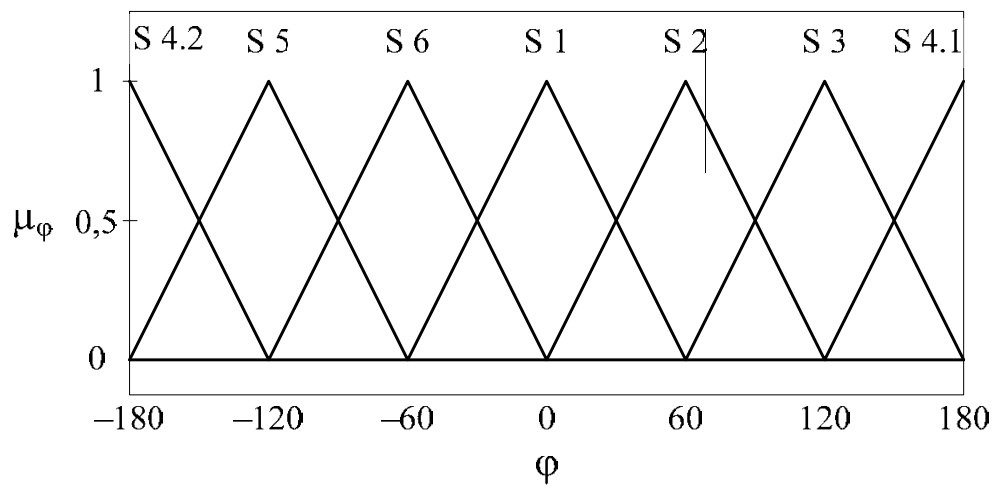

2.14 pav. Fazės priklausomybės funkcijos

Fig. 2.14. Membership functions of phase

Tipinis ir neraiškiosios logikos tiesioginis momento valdymo būdai išbandyti įvairiais darbo režimais. Taikytos pavaros bandymų sąlygos atitinka skaliarinės pavaros atveji:

- $\quad$ variklio parametrai pagal 2.2 lentelę,

- paleidimas ir stabdymas su pagreičio ribojimu - $100 \mathrm{rad} / \mathrm{s}^{2}$,

- greičio nuostatis - $50 \mathrm{rad} / \mathrm{s}$,

- statinè apkrova nuo laiko momento $1,5 \mathrm{~s}$ iki 4,5 s.

Tiesioginio momento valdymo pavaroms ịejjimo signalai yra elektromagnetinio sukimo momento ir statoriaus magnetinio srauto nuostačiai. Pastarasis dydis yra palaikomas pastovus, parinktas pagal variklio konstrukciją, siekiant užtikrinti aukštą galios naudingumo koeficientą arba didelị maksimalų sukimo momentą.

Sukimo momento nuostatis gali būti valdomas dinamiškai. Tyrimams pasirinkta uždara valdymo sistema su greičio grižtamuoju ryšiu. Greičio paklaida apdorojama PI (proporciniu-integraliniu) reguliatoriumi ir suformuotas signalas tampa sukimo momento nuostačiu. Šis reguliatorius suprojektuotas užtikrinti labai mažas pavaros sukimosi greičio paklaidas.

Imitacinių tyrimų tikslas yra palyginti tipinį TMV ir TMV su neraiškiosios logikos reguliatoriumi (NLTMV). Abiem pavaroms yra užduoti analogiški valdymo signalai. Imitacinių tyrimų rezultatai, kai magnetinio srauto nuostatis yra $0,7 \mathrm{~Wb}$ o apkrovos momentas $-25 \mathrm{~N} \cdot \mathrm{m}$.

Imitaciniai sukimosi greičio pereinamujų vyksmų rezultatai yra pateikti 2.15 paveiksle. 
a)

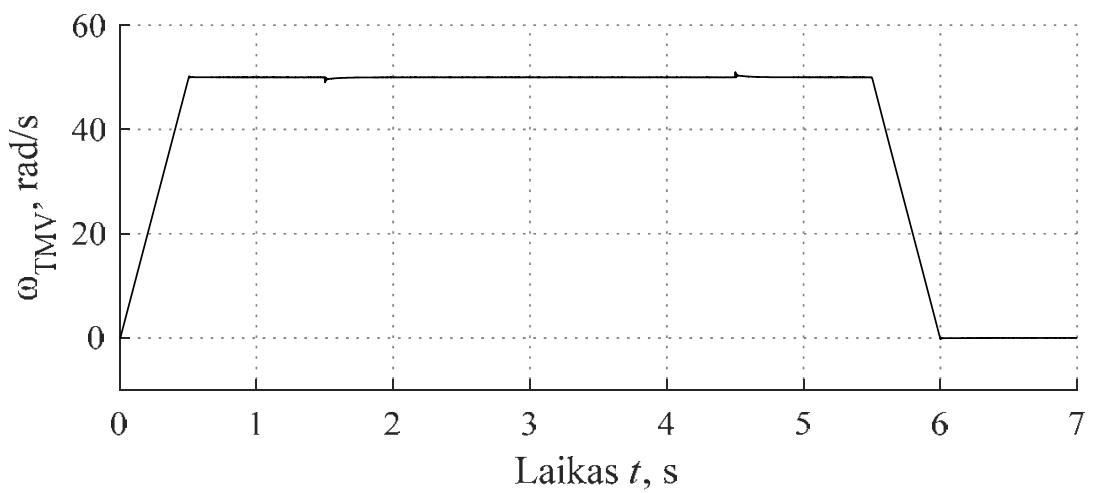

b)

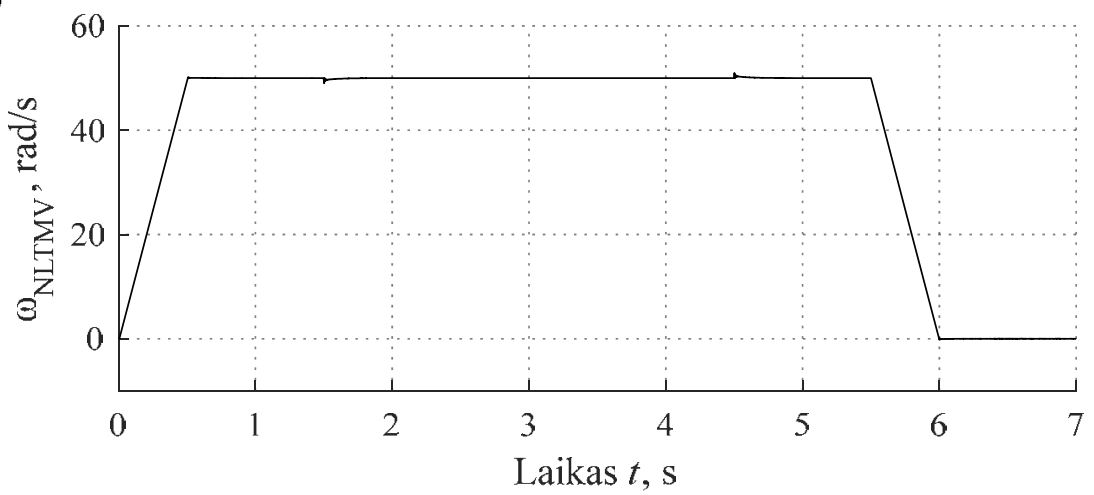

2.15 pav. Vektorinio valdymo pavaros imitaciniai rotoriaus sukimosi greičio pereinamieji vyksmai: a) tipinis tiesioginis momento valdymas; b) tiesioginis momento valdymas su neraiškiosios logikos reguliatoriumi Fig. 2.15. Simulated rotor velocity transients of drive using vector control: a) typical direct torque control; b) direct torque control with fuzzy logic controller

2.15 paveiksle pateiktas neraiškiosios logikos valdymo greičio pereinamųjų vyksmų grafikas sutampa su tipinio TMV grafiku dėl aukštų dinaminių kokybės rodiklių. Gautos dinaminès paklaidos siekia mažiau nei $1 \%$. Šuoliai apkrovos ijungimo ir išjungimo metu sutampa (laiko momentais 1,5 s ir 4,5 s).

Tokie greičio pereinamieji vyksmai įmanomi tik tuo atveju, kai elektromagnetinis sukimo momentas kinta šuoliškai. Tai matyti 2.16 paveiksle. Elektromagnetinių sukimo mementų akimirkinès vertès nèra filtruotos, nes tipinio TMV ir NLTMV valdymo būdų skirtumas yra šios aukšto dažnio pulsacijos. Galima pastebėti, kad švytavimų amplitudès skiriasi. 
a)
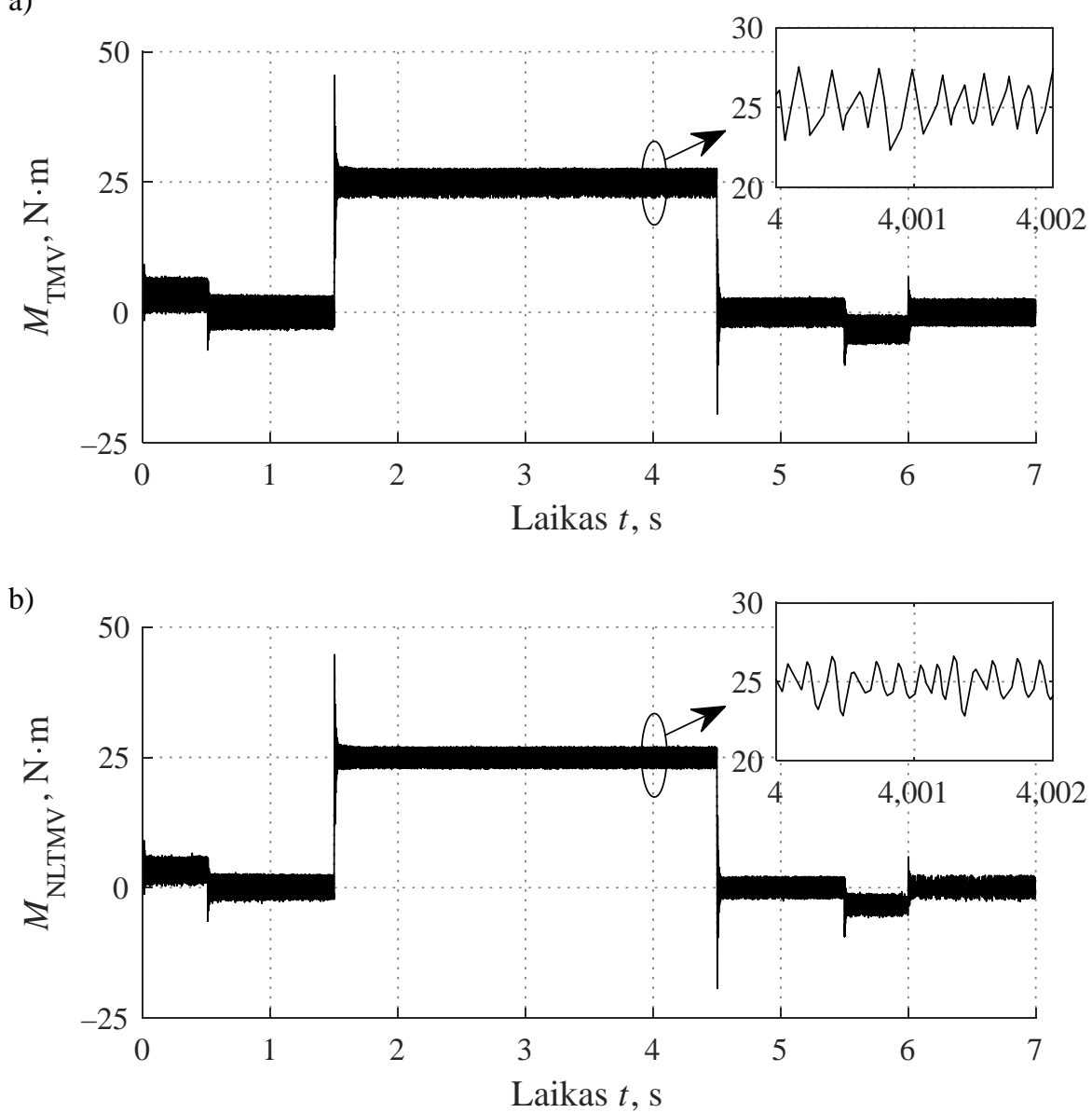

2.16 pav. Vektorinio valdymo pavaros imitaciniai elektromagnetinio sukimo momento pereinamieji vyksmai: a) tipinis tiesioginis momento valdymas; b) tiesioginis momento valdymas su neraiškiosios logikos reguliatoriumi

Fig. 2.16. Simulated electromagnetic torque transients of drive using vector control: a) typical direct torque control; b) direct torque control with fuzzy logic controller

Neskaitant aukšto dažnio dedamụjų, statoriaus fazinès srovès yra labai artimos abiejų valdymo būdų atvejais (2.17 pav.). Apkrovos metu stebimas aukštesnis fazinis dažnis, kitų režimų metu. 
a)

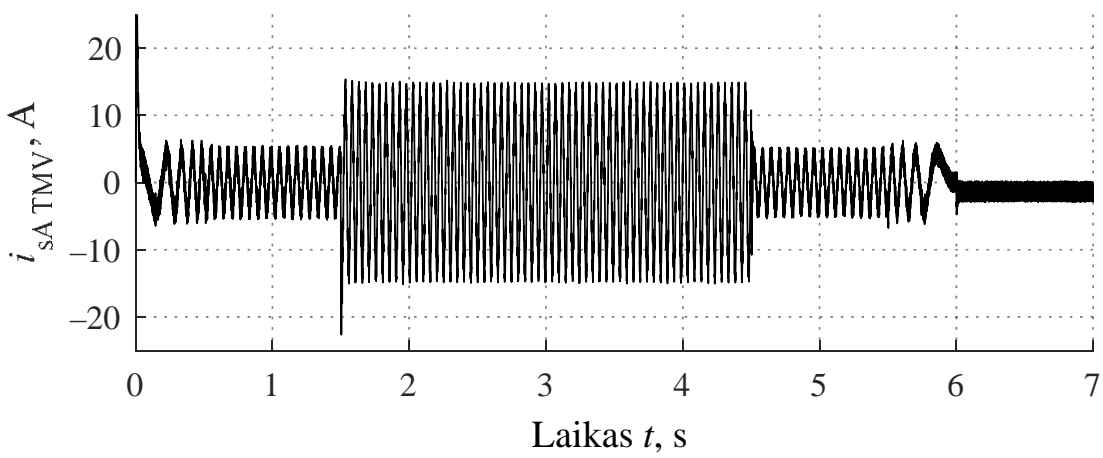

b)

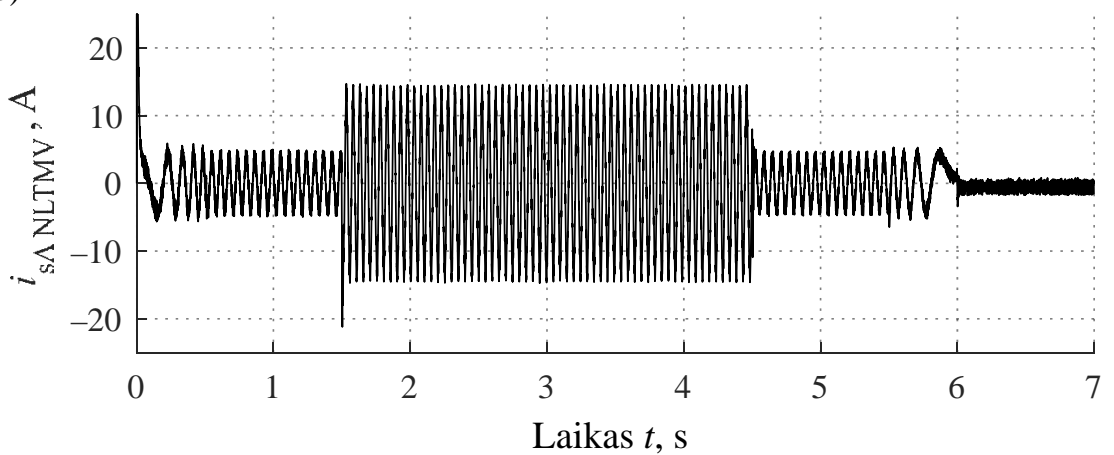

2.17 pav. Vektorinio valdymo pavaros imitaciniai statoriaus A fazės akimirkinès srovès pereinamieji vyksmai: a) tipinis tiesioginis momento valdymas; b) tiesioginis momento valdymas su neraiškiosios logikos reguliatoriumi

Fig. 2.17. Simulated stator phase A instantaneous current transients of drive using vector control: a) typical direct torque control; b) direct torque control with fuzzy logic controller

Pavaros statoriaus magnetinio srauto amplitudė yra palaikoma pastovi, tačiau gali koreguojama. Siekiant ịvertinti reguliatoriaus tinkamumą plačiam valdymo signalų diapazonui atlikti imitaciniai bandymai su šiais darbo sąlygų variantais:

- magnetinio srauto nuostatis - 0,7 Wb, statinis apkrovos momentas laiko tarpu nuo $1,5 \mathrm{~s}$ iki $4,5 \mathrm{~s}-25 \mathrm{~N} \cdot \mathrm{m}$,

- magnetinio srauto nuostatis - 1,4 $\mathrm{Wb}$, statinis apkrovos momentas laiko tarpu nuo $1,5 \mathrm{~s}$ iki $4,5 \mathrm{~s}-50 \mathrm{~N} \cdot \mathrm{m}$,

- magnetinio srauto nuostatis - 2,1 Wb, statinis apkrovos momentas laiko tarpu nuo $1,5 \mathrm{~s}$ iki $4,5 \mathrm{~s}-75 \mathrm{~N} \cdot \mathrm{m}$. 
a)
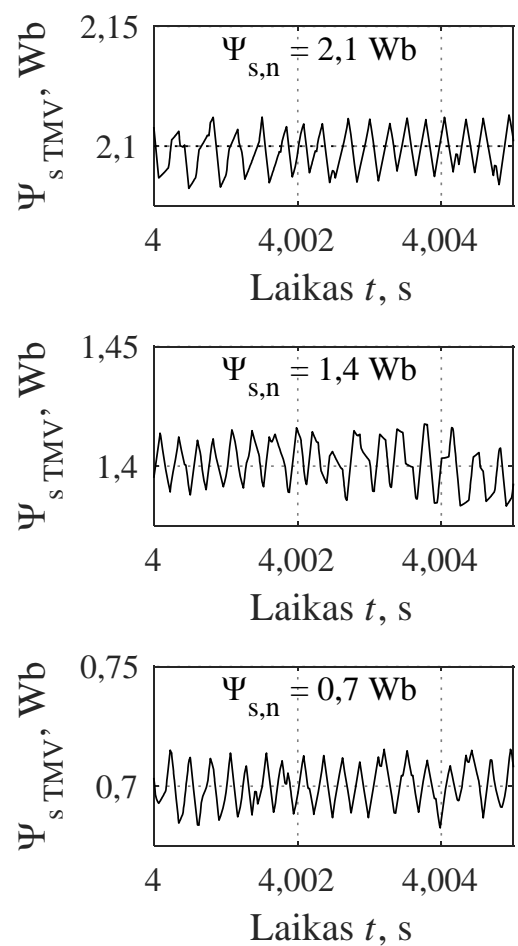

b)
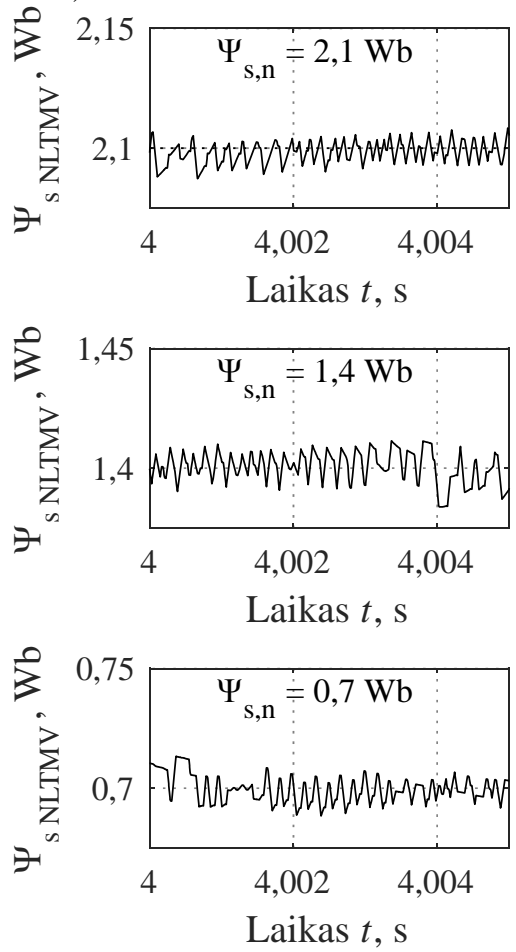

2.18 pav. Imitaciniai statoriaus magnetinio srauto pereinamieji vyksmai: a) tipinis tiesioginis momento valdymas; b) tiesioginis momento valdymas su neraiškiosios logikos reguliatoriumi

Fig. 2.18. Simulated stator magnetic field vector trajectories: a) typical direct torque control; b) direct torque control with fuzzy logic controller

2.18 paveiksle pateikta laiko atkarpa (4-4,005 s) yra apkrovos metu. Čia matyti, kad abiem TMV variantais statoriaus magnetinis srautas išlaikomas artimas nuostačiui, tačiau stebimos skirtingos amplitudès pulsacijos. Elektromagnetinio sukimo momento ir statoriaus magnetinio srauto ịvertinimui apskaičiuoti vidutiniai nuokrypiai nuo valdymo signalų:

$$
\begin{aligned}
& \sigma_{\Psi}=\frac{1}{N} \sum_{k=1}^{N}\left|e_{\Psi}(k T)\right|, \\
& \sigma_{M}=\frac{1}{N} \sum_{k=1}^{N}\left|e_{M}(k T)\right| .
\end{aligned}
$$


2.6 lentelė. Magnetinio srauto ir sukimo momento pereinamųjų vyksmų palyginimo lentelè

Table 2.6. Comparison table for magnetic flux and torque transients

\begin{tabular}{|l|l|l|l|l|l|l|}
\hline \multirow{2}{*}{$\begin{array}{l}\text { Magneti- } \\
\text { nio srauto } \\
\text { nuostatis }\end{array}$} & \multicolumn{3}{|l|}{$\begin{array}{l}\text { Vidutinis magnetinio srauto } \\
\text { nuokrypis, Wb }\end{array}$} & $\begin{array}{l}\text { Vidutinis sukimo momento } \\
\text { nuokrypis, N·m }\end{array}$ \\
\cline { 2 - 7 } & TMV & NLTMV & Santykis & TMV & NLTMV & Santykis \\
\hline $2,1 \mathrm{~Wb}$ & 0,0068 & 0,0045 & $65 \%$ & 3,63 & 3,34 & $92 \%$ \\
\hline $1,4 \mathrm{~Wb}$ & 0,0068 & 0,0044 & $65 \%$ & 2,25 & 2,05 & $91 \%$ \\
\hline $0,7 \mathrm{~Wb}$ & 0,0068 & 0,0051 & $74 \%$ & 1,02 & 0,75 & $74 \%$ \\
\hline
\end{tabular}

2.6 lentelëje pateiktas tipinio TMV ir TMV su neraiškiosios logikos reguliatoriumi paklaidų santykis esant trims skirtingoms nuostačio ir apkrovos momento vertėms. Visais atvejais siūlomas reguliatorius pagerino dinaminius rodiklius vertinant darbą keliuose darbo taškuose (paleidimas, tuščioji veika, apkrova ir stabdymas). Taikant neraiškiają logiką, vidutiniai magnetiniai nuokrypiai yra nuo 26 iki 35 \% mažesni, o vidutiniai sukimo momento nuokrypiai mažesni nuo 8 iki $26 \%$.

\subsection{Antrojo skyriaus išvados}

1. Sudarytas neraiškiosios logikos reguliatorius supaprastina pavaros modelio struktūrą, apjungdamas momento ir srauto histerezès kilpas ir vektorių parinkimo lentelę.

2. Sukurtas tiesioginio momento valdymo pavaros imitacinis modelis su momento ir magnetinio srauto valdymui naudojamu neraiškiosios logikos reguliatoriumi, tiesiogiai valdančiu inverterio raktus, pagerino dinaminius rodiklius keliuose pavaros darbo taškuose (paleidimas, tuščioji veika, apkrova ir stabdymas).

3. Tipinị tiesioginị momento valdymą pakeitus neraiškiosios logikos valdymu galima pagerinti pavaros dinamines savybes išlaikant labai aukštą greičio valdymo tikslumą.

4. Tiesioginis momento valdymas su neraiškiosios logikos reguliatoriumi pagerina dinaminius rodiklius lyginant su tipiniu tiesioginio momento valdymo atveju - sumažina elektromagnetinio momento pulsacijas $26 \%$, o statoriaus magnetinio srauto - $26 \%$, kai užduotas mažas magnetinio srauto nuostatis $(0,7 \mathrm{~Wb})$. Uždavus didelę nuostačio vertę 
(2,1 Wb), elektromagnetinio momento pulsacijos sumažinamos $8 \%$, o statoriaus magnetinio srauto - $35 \%$.

5. Esant vienodam nuostato signalui, neraiškiosios logikos valdymas sumažina nepageidaujamų elektromagnetinio momento ir statoriaus srauto švytavimų amplitudę iki dviejų kartų. 



\section{Šešiafazių pavarụ valdymas esant poavariniam režimui}

Šiame skyriuje ištirtas poavarinio režimo kompensavimo metodas, sukurtas algoritmas šio metodo fazinių kampų paieškai ir pateikta šio skaliarinio valdymo reguliatoriaus, pritaikančio kompensavimą plačiame dažnių ir apkrovų diapazone, sudarymo metodiką.

Skyriaus tematika paskelbtas vienas straipsnis (Pitrėnas, Uznys, Beištaras 2017).

\subsection{Eksperimentinis bandymų stendas}

Daugiafazėms pavaroms tirti sukurtas specialus tyrimų stendas Vilniaus Gedimino technikos universitete Automatikos katedroje. Visą šios disertacijos rengimo laikotarpi, stendas buvo vystomas - plečiamos jo galimybės ir gerinama matavimų kokybè.

Tyrimų stendas yra sudarytas iš šešiafazio simetrinio asinchroninio variklio, šešiafazio dažnio keitiklio, sukimosi greičio ir sukimo momento jutiklio (Lorenz Messtechnik GmbH DR-2212), šešiu srovès matavimo replių (Hameg HZO50), septynių magnetinio srauto jutiklių (BCD Semiconductor Manufacturing Limited 
linear Hall effect IC AH49H) ir nuolatinès srovès generatoriaus, kuriuo apkraunama tiriama pavara (Femsan K.09.15), 16 kanalų analoginių duomenų rinkimo sistemos (National Instruments PCI-6024E) ir asmeninio kompiuterio. Tyrimų stendo funkcinè schema pateikta 3.1 paveiksle.

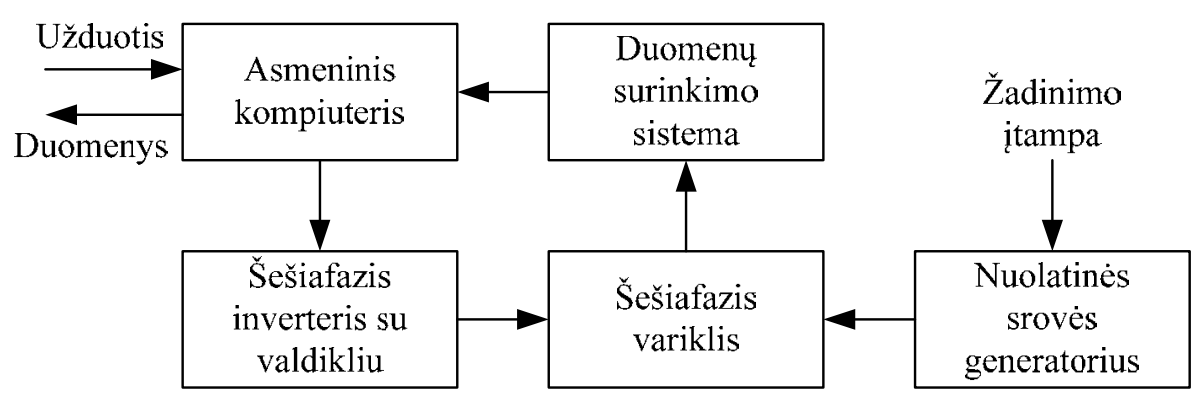

3.1 pav. Eksperimentinių tyrimų stendo funkcinè schema

Fig. 3.1. Functional block diagram of experimental test rig

Remiantis moksline literatūra - elipsinè šio režimo statoriaus srovių suminio vektoriaus trajektorija kuria elipsinị magnetinị lauką. Keičiant maitinimo įtampų fazinius kampus ir išlaikant nepakeistą amplitudę, pavyko pakeisti minėtą srovės trajektoriją - elipsinè forma atstatyta ị apskritiminę.

Pastebėta, kad apskritiminę trajektoriją galima atstatyti su įvairiais fazinių kampų rinkiniais, t. y. toks kriterijus turi daug sprendinių. Nuspręsta pašalinti dar vieną neigiamą poveikị turintị reiškinị - viršsrovius statoriaus apvijose. Lyginant su normaliuoju režimu 40 \% išaugusi srovè vienoje iš apvijų gali pakenkti pavarai - keitikliui arba variklio apvijų izoliacijai.

Siekiant ịsitikinti, kad prielaidos apie magnetinio srauto vektoriaus trajektorijos formą yra teisingos, ị eksperimentinị stendą įdiegti Holo jutikliai šiam variklio srautui matuoti. Su Mechanikos fakulteto pagalba variklio statoriuje buvo ịrengtos vietos šiems jutikliams.

Tyrimams svarbus ne statoriaus ar rotoriaus magnetinis srautas, o srautas oro tarpe. Dèl asinchroninių variklių konstrukcinių ypatumų oro tarpas tarp statoriaus ir rotoriaus yra labai mažas ir jame patalpinti srauto jutiklius yra sunkiai įmanoma. Todèl geriausia alternatyva yra jutiklių ịrengimas statoriaus magnetolaidyje.

Eksperimentinių bandymu metu pastebèta, kad magnetinis srautas beveik visame statoriaus danties (išsikišusios magnetolaidžio dalies tarp apvijų griovelių) paviršiuje yra vienodas. Vadinasi, srautas šiose dalyse pasiskirsto vienodai ir jutikliu pozicionavimo netikslumai nesukels didelių matavimo paklaidų. 
Magnetinio srauto trajektorijai nubraižyti teoriškai užtenka dviejų srauto jutiklių išdėstytų 90 elektrinių laipsnių kampu, tačiau siekiant patikrinti šios prielaidos teisingumą, įrengta daugiau magnetinio srauto jutiklių.

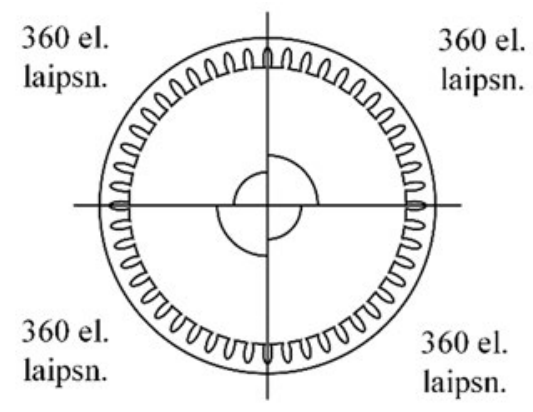

a)

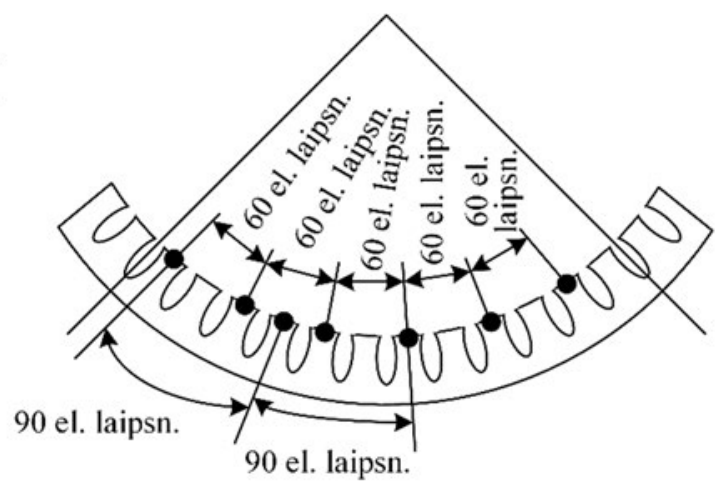

b)

3.2 pav. Variklio statoriaus skersinis pjūvis: a) keturių polių porų statoriaus elektriniai kampai; b) magnetinio srauto jutiklių išdėstymas statoriaus magnetolaidyje

Fig. 3.2. Motor stator cross-section: a) electric angles of stator with four pole pairs; b) positions of magnetic flux sensors in the magnetic circuit

Pirmiausia, sudarant 90 elektrinių laipsnių kampą reikia įvertinti variklio statoriaus konstrukciją (3.2 pav. a). Su 4 polių porų statoriumi, Holo jutiklių matavimo kryptys turi sudaryti keturi kartus mažesnị erdvinị kampą brèžiant linijas iš statoriaus vidurio taško, t. y. 22,5, vietoje $90^{\circ}$. Kitu atveju, gaunamas identiškas fazinis kampas.

Tiriamas variklis turi statorių su 48 grioveliais apvijoms. Po 12 griovelių tenka vienai poliu porai. Norint gauti 90 elektrinių laipsnių kampą jutikliai pasirinktuose nuosekliai išdėstytuose dantyse išdèstyti ị kas trečią poziciją: 1,4 ir 7 magnetolaidžio dantys (3.2 pav. b).

Kaip matyti iš 3.3 paveikslo statoriaus srauto dedamujų fazių skirtumai yra ne vienodi ir lygūs $148^{\circ}$ ir $180^{\circ}$ kampams. Srautų fazių skirtumai yra ne lygūs $90^{\circ}$ kampui, nes tiriamas šešiafazis variklis turi suklotą dvisluoksnę sutrumpinto žingsnio apviją. Tokio tipo apvijoje kai kurios fazès yra klojamos ị tą patị statoriaus magnetolaidžio griovelį, tai apsunkina tiesioginį statoriaus magnetinio srauto matavimą. Taip pat magnetinio srauto kreivèse matomi aukštesnio dažnio harmonika, kuri turi tik teigiamąą dedamają. Ši aukštesniosios eilès harmonika susidaro dèl statoriaus ir rotoriaus konstrukcijos ypatumų, bei jų tarpusavio magnetinių ryšių. 
a)

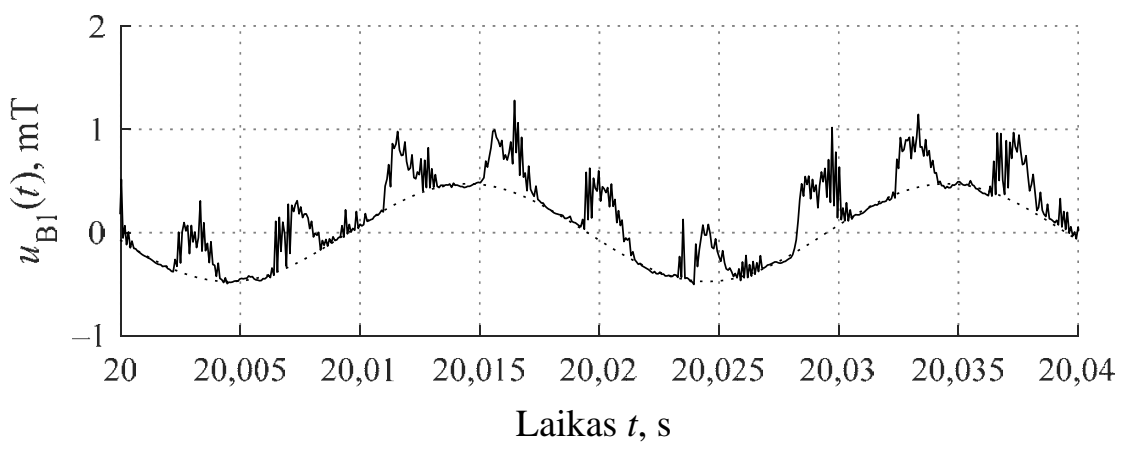

b)

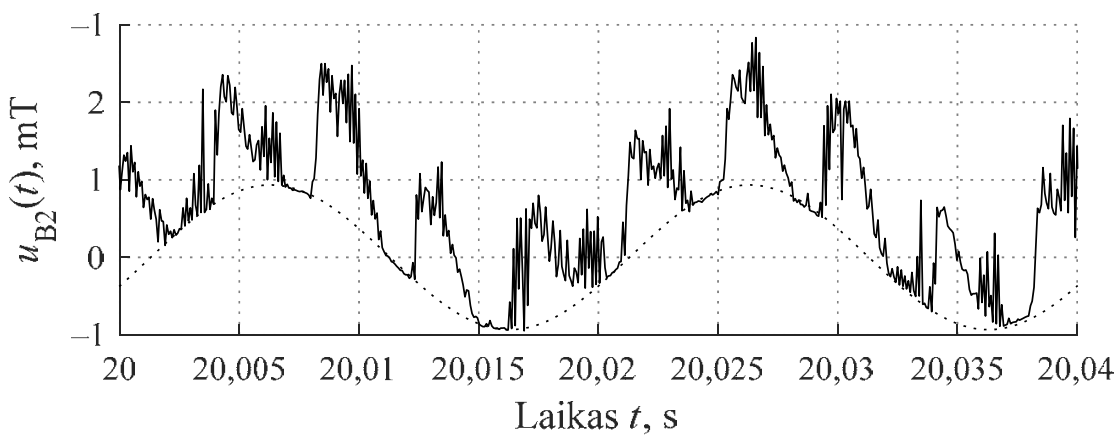

c)

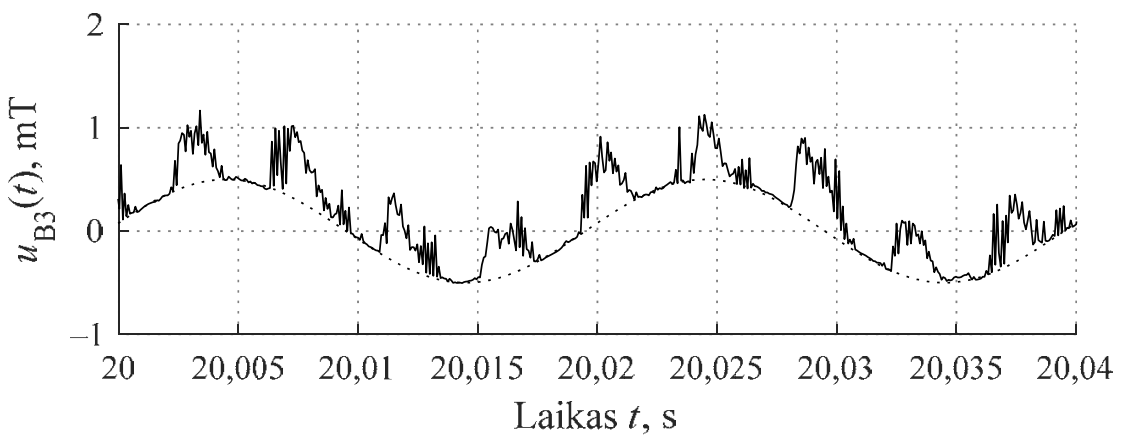

3.3 pav. Magnetinio srauto matavimai naudojant tris ortogonaliai išdejstytus Holo efekto jutiklius: a) erdviné pozicija $-0^{\circ}$; b) erdviné pozicija $-90^{\circ}$;

c) erdvinè pozicija $-180^{\circ}$

Fig. 3.3. Magnetic flux density measurements with three orthogonally positioned Hall effect sensors: a) spatial position $-0^{\circ}$; b) spatial position $90^{\circ}$; c) spatial position $-180^{\circ}$ 


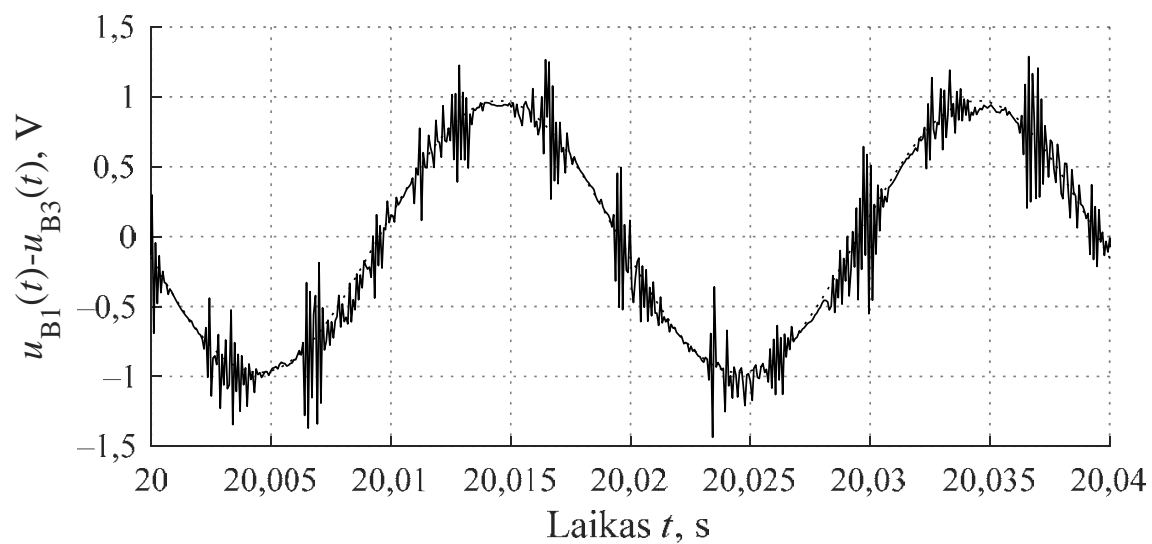

3.4 pav. Dviejų magnetinio srauto matavimo dedamụjų, kurių fazės skiriasi $180^{\circ}$, skirtumas

Fig. 3.4. Difference of two magnetic flux measurement components with phase shift of $180^{\circ}$

Kadangi aukštesniosios harmonikos turi tik teigiamąją dedamają buvo suskaičiuotas skirtingų fazių, kurios tarpusavyje skiriasi 180 el. laipsnių, kuriamo magnetinio srauto skirtumas (3.4 pav.). Matyti, kad suskaičiavus priešingų fazių kuriamo magnetinio srauto matavimų skirtumą aukštesniosios harmonikos kompensuojasi, o ịtampos amplitudès vertė padidejja 2 kartus. Šis reiškinys matomas ir atlikus magnetinių srautų dažnių spektro sudèties analizę.

Vienos fazès kuriamo magnetinio srauto $B_{1}$ ir dviejų priešingų fazių magnetinio srauto matavimų skirtumo $u_{\mathrm{B} 1}(t)-u_{\mathrm{B} 3}(t)$ greitoji Furjè transformacija (angl. fast Fourier transform, FFT) pateikta 3.5 paveiksle.

Kaip matyti iš 3.5 paveikslo magnetiniame sraute, kuris gautas naudojant tik vieno magnetinio srauto jutiklio signalą $u_{\mathrm{B} 1}(t)$, egzistuoja aukštesniosios eilès harmonika, kurios dažnis $237,7 \mathrm{~Hz}$, o amplitudè $0,195 \mathrm{~V}$, pagrindinès harmonikos dažnis $50 \mathrm{~Hz}$, o amplitudè 0,338 V.

Suskaičiuoto dviejų magnetinio srauto jutiklių signalų skirtumo spektrinëje sudètyje nelieka anksčiau minètos aukštesniosios eilès harmonikos, pagrindinės harmonikos amplitudè padidẻja iki 0,692 V, o dažnis nepakinta ir yra lygus $50 \mathrm{~Hz}$.

Atlikus šiuos tyrimus galima teigti, kad norint tiksliai išmatuoti šešiafazio asinchroninio variklio statoriaus kuriamo magnetinio srauto tankị oro tarpe reikia naudoti mažiausiai du srauto jutiklius, kurie turi būti sumontuoti viename statoriaus dantyje, bei matuoti srautą priešingomis kryptimis. Toks jutiklių montavimo būdas dèl jutiklių ir pačio statoriaus magnetolaidžio dantų išmatavimų yra sudètingas, tačiau panašus rezultatas gali būti pasiekiamas matuojant dviejų pozicijų, 
kurių fazinis kampas lygus 180 elektrinių laipsnių, kuriamus magnetinius srautus ir skaičiuojant jų skirtumą.

a)

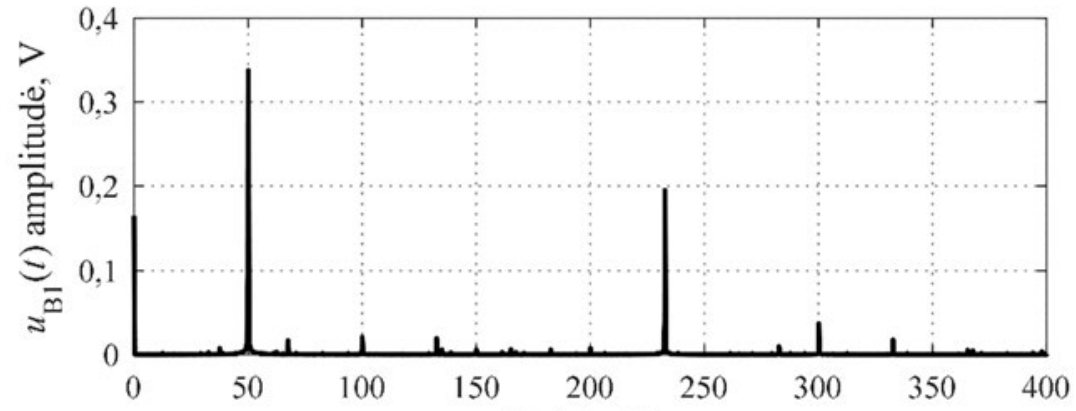

b)

Dažnis, Hz

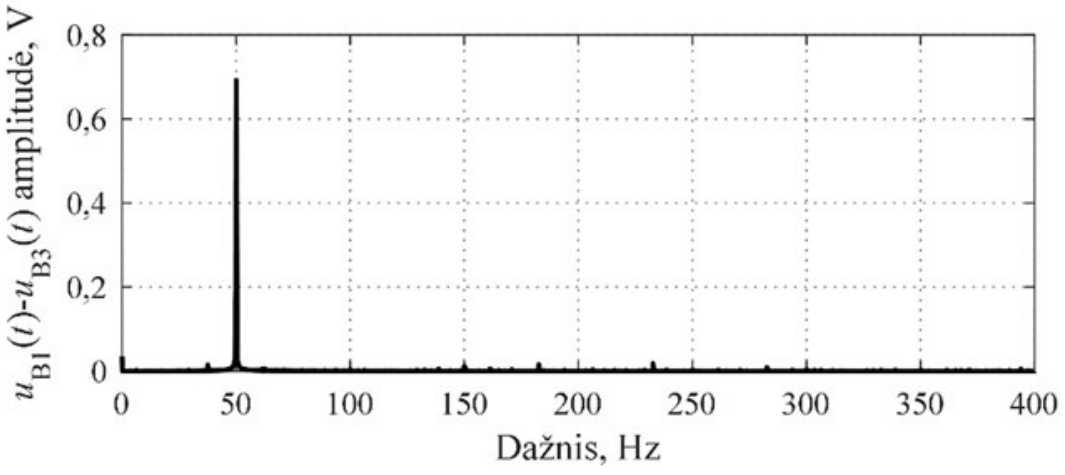

3.5 pav. Amplitudžiu spektrai: a) vienas magnetinio srauto matavimo įtampa; b) dviejų magnetinio srauto matavimų įtampų, kurių fazès skiriasi $180^{\circ}$, skirtumas

Fig. 3.5. Amplitude spectrums: a) single magnetic flux measurement voltage; b) difference of two magnetic flux measurement voltages with phase shift of $180^{\circ}$

Pasiūlytas tiesioginis statoriaus magnetinio srauto matavimo būdas taikomas kuriant šešiafazės asinchroninės pavaros poavarinio režimo valdymo metodą. Šis matavimo būdas, taip pat gali būti taikomas ir šešiafazių asinchroninių pavarų vektorinio valdymo algoritmams kurti.

Tyrimų stendo, pritaikyto vienu metu matuoti statoriaus sroves ir magnetinio srauto tanki oro tarpe, bendras vaizdas pateiktas 3.6 paveiksle. 


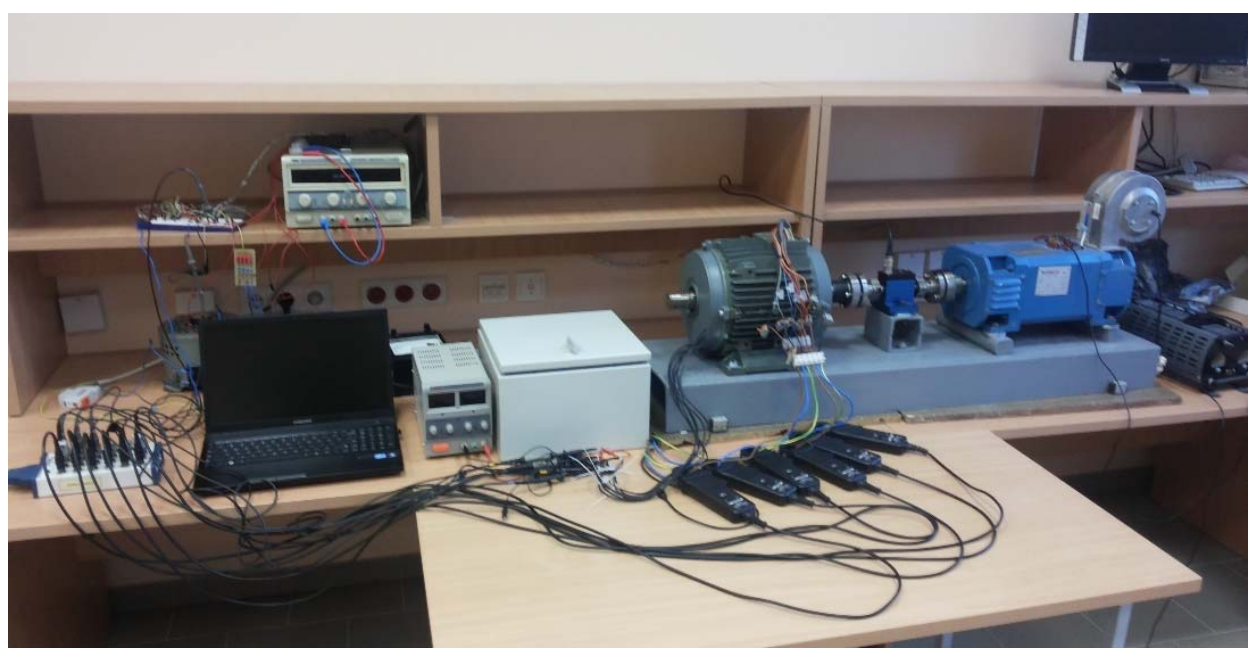

3.6 pav. Eksperimentinio tyrimų stendo bendras vaizdas (iš kairès ị dešinę): šešiafazis dažnio keitiklis, šešiafazis asinchroniniais variklis, sukimo momento jutiklis, nuolatinès srovès generatorius

Fig. 3.6. Experimental test rig (left to right): six-phase voltage source inverter, six-phase induction motor, torque sensor, dc generator as load

Visi eksperimentiniai matavimai buvo atlikti naudojant Matlab programini paketą ir skaitmeninę duomenų surinkimo sistemą, kurioje yra 16 analoginių i̇èjimų. Duomenų surinkimo sistemos įejimų ribos yra $\pm 0,5 \mathrm{~V}, \pm 5 \mathrm{~V}$ arba $\pm 10 \mathrm{~V}$, o maksimalus kvantavimo periodas $1 \mathrm{MS} / \mathrm{s}$. Duomenų surinkimo sistemoje naudojamas 12 skilčių analoginis skaitmeninis keitiklis, kuris matuoja prie sistemos įèjimų prijungtus analoginius signalus ir keičia juos skaitmeninėmis vertėmis. Matavimų duomenys tiesiogiai išsaugomi Matlab programiniame pakete, kur jie vėliau ir apdorojami.

Eksperimentiniai šešiafazio asinchroninio variklio parametrai pateikti 3.1 lentelèje.

3.1 lentelè. Eksperimentinio šešiafazio asinchroninio variklio parametrai Table 3.1. Parameters of experimental six-phase induction motor

\begin{tabular}{|l|l|l|l|l|l|l|l|}
\hline Dydis & $U, \mathrm{~V}$ & $P_{\mathrm{n}}, \mathrm{kW}$ & $\omega_{\mathrm{n}}, \mathrm{rad} / \mathrm{s}$ & Polių skaičius & $\cos \varphi$ & $R_{\mathrm{s}}, \Omega$ & $J, \mathrm{~kg} \cdot \mathrm{m}^{2}$ \\
\hline Verte & 230 & 1,7 & 75 & 8 & 0,6 & 5,9 & 0,0114 \\
\hline
\end{tabular}

Pristatytas šešiafazès asinchroninès dažninės pavaros eksperimentinių tyrimų stendas gali būti taikomas edukaciniams tikslams ir tolimesniems pavaros valdymo tyrimams. 


\subsection{Dažninès pavaros normaliojo ir poavarinio režimo tyrimas}

Tiriamas šešiafazès asinchroninès pavaros poavarinis režimas (angl. post-fault conditions). Konkrečiai nagrinėjamas tik prarastų (nutrūkusių) apvijų atvejis. İvairūs gedimai gali sukelti sutrikimus atskirose apvijose. Kai kurios techninės apsaugos priemonès izoliuoja pažeistas apvijas ir pavara gali tęsti darbą. Paradus statoriaus fazes reikia kompensuoti neigiamus padarinius.

Gedimas eksperimentuose - trūkstama statoriaus fazè - yra imituotas atjungiant vieną iš variklio statoriaus fazinių laidų nuo šešiafazio keitiklio. Visame šiame poskyryje pateikiami tik tuščiosios veikos matavimai, tačiau eksperimentai buvo atlikti ir su apkrauta pavara. Taip pat, maitinimo ịtampos dažnis yra $50 \mathrm{~Hz}$, tačiau bandymai atlikti platesniame dažnių diapazone išlaikant pastovų skaliarinės pavaros U/f santykị.

Kaip minèta anksčiau (Pitrėnas et al. 2017), buvo pasiūlytas statoriaus srovès atstojamojo vektoriaus trajektorijos ir fazinių viršsrovių kompensavimo metodas. Tačiau nebuvo atlikti magnetinio srauto oro tarpe tyrimai. Šioje disertacijoje atlikti tiesioginiai magnetinio srauto tankio oro tarpe matavimai. Taip pat sudarytas specializuotas parametrų paieškos metodas.

Vienas iš neigiamų poavarinio režimo padarinių - viršsroviai. Pasiūlytu metodu pavyko suvienodinti srovių amplitudes ir taip sumažinti viršsrovius. Juo taip pat kompensuota atstojamojo statoriaus srovių vektoriaus trajektorija - iš elipsinès atstatyta ị apskritiminę.

Eksperimentai atliekami kaupiant statoriaus srovès ir magnetinio srauto tankio jutiklių duomenis 30 sekundžiu trukmès įrašuose vienu metu matuojant visus 12 reikiamų kanalų vienu metu. Nagrinėjama tik paskutinės 20 sekundžių įrašo, taip užtikrinant, kad pereinamieji pavaros paleidimo vyksmai yra visiškai pasibaigę. Svarbu atkreipti dėmesị, kad srovės ir srauto matavimų fazinis kampas nėra lygus nuliui. Statoriaus fazinès srovès $i_{\mathrm{A}}(t)$ (fazès A) vektoriaus kryptis nesutaps su srauto tankio $B_{1}(t)$ (indeksu 1 ) kryptimi. Šis kalibravimo trūkumas neiškreipia kokybinių rodikliu - srauto tankio atstojamojo vektoriaus kryptis nėra aktuali atliekamiems tyrimams.

3.7 paveikslo a dalyje matomi akimirkinių statoriaus srovių amplitudžių iškraipymai, kai pavara dirba vienos nutrūkusios fazės poavariniu režimu. Normaliojo režimo atveju, kai maitinimo įtampos yra simetrinès, statoriaus srovių amplitudès būtų lygios.

Netaikant kompensavimo metodo, faziniai maitinimo įtampų kampai yra [0 $60^{\circ} 120^{\circ} 180^{\circ} 240^{\circ} 300^{\circ}$ ], tačiau 3.7 paveiksle galima pastebèti, kad fazinis statoriaus srovių kampas tarp gretimų fazių poavarinio režimo metu yra kitoks nei maitinimo įtampų. 
a)

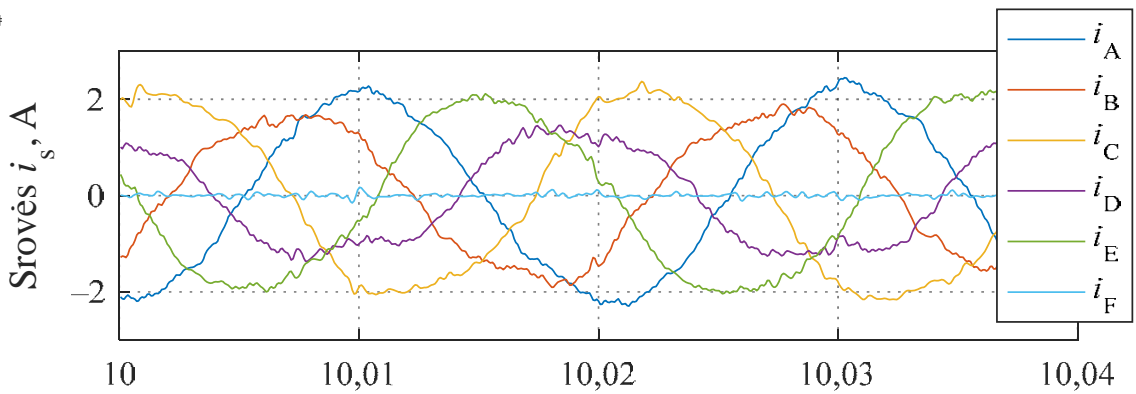

b)

Laikas $t, \mathrm{~s}$

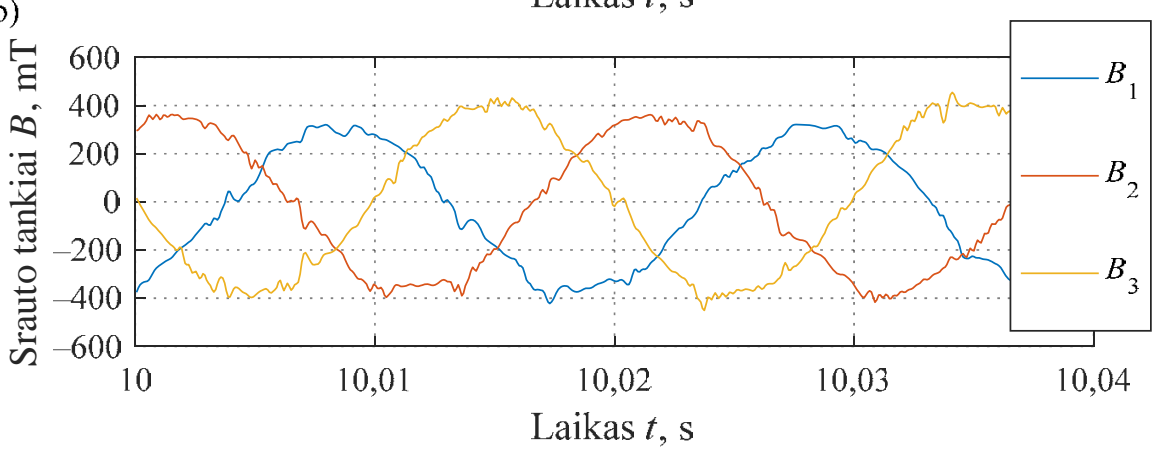

3.7 pav. Eksperimentinès akimirkinès vertės nekompensuoto poavarinio režimo metu - be F fazès, kai maitinimo ịtampos dažnis - $50 \mathrm{~Hz}$ :

a) statoriaus akimirkinès srovės; b) magnetinio srauto tankiai oro tarpe

Fig. 3.7. Experimental instantaneous values in uncompensated post-fault condition (loss of phase F) when source voltage frequency is $50 \mathrm{~Hz}$ :

a) instantaneous stator currents; b) magnetic flux densities in the air gap

Magnetinio srauto tankiai oro tarpe yra išsidèstę su apytikriai $120^{\circ}$ faziniu kampu (3.7 pav. b). Kokybiniam procesų ịvertinimui pasirinktas akimirkinių verčių atvaizdavimas atstojamojo vektoriaus trajektorija. Ji gaunama skaičiuojant projekcijas ị dvimatę koordinačių sistemą, nejudančią ir sutampančią su variklio statoriaus skersiniu pjūviu. Variklio matematiniame modelyje tai vadinama transformacija i $\alpha-\beta$ koordinačių sistemą.

$$
\begin{aligned}
& B_{\alpha}(t)=2 / 3\left(\sin (0) \cdot B_{1}(t)+\sin (2 \pi / 3) \cdot B_{2}(t)+\sin (4 \pi / 3) \cdot B_{3}(t)\right), \\
& B_{\beta}(t)=2 / 3\left(\cos (0) \cdot B_{1}(t)+\cos (2 \pi / 3) \cdot B_{2}(t)+\cos (4 \pi / 3) \cdot B_{3}(t)\right) .
\end{aligned}
$$

Naudojami šeši jutikliai išdèstyti kas 60 elektrinių laipsnių. Elektrinio kampo atžvilgiu priešpriešai išdèstytų jutiklių matavimai sumuojami taip užtikrinant 
žemą triukšmų lygị. Iš viso išmatuoti magnetiniai srautai trimis kryptimis, kurios sudaro 120 elektrinių laipsnių. Magnetinių srautų trajektorijos tokiu atveju gaunamos skaičiuojant projekcijoms ị ortogonalias ašis, t. y. taikant 3.1 ir 3.2 formules.

Pavaros, veikiančios vienos trūkstamos fazės poavarinėmis sąlygomis, statoriaus srovių ir magnetinio srauto sistemų analizè pateikta 3.8 paveiksle.

a)

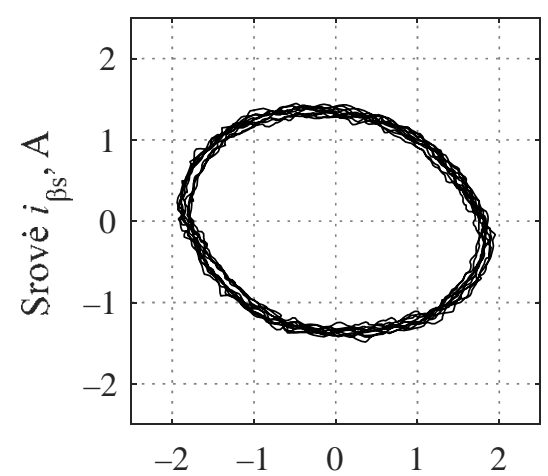

c)

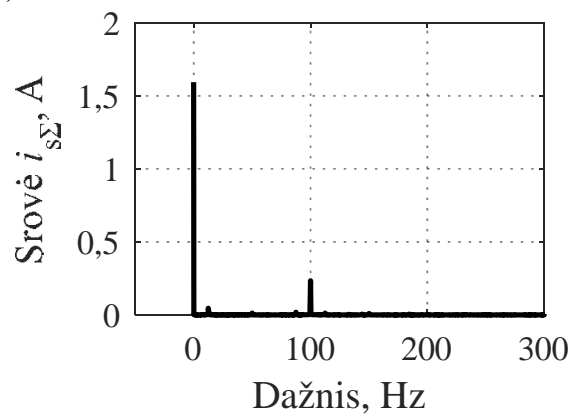

b)

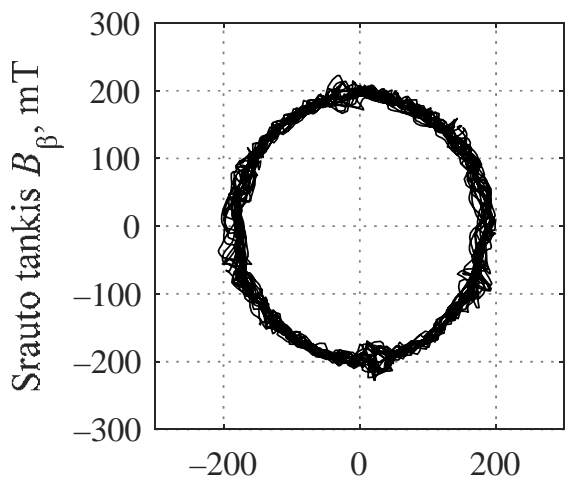

d)

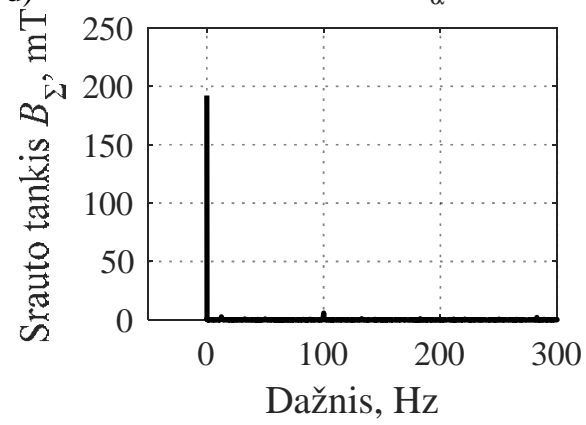

3.8 pav. Eksperimentiniai atstojamieji vektoriai nekompensuoto poavarinio režimo metu - be F fazès: a) statoriaus fazinių srovių atstojamojo vektoriaus trajektorija; b) magnetinio srauto tankio oro tarpe trajektorija; c) statoriaus fazinių srovių atstojamojo vektoriaus amplitudžiu spektras; d) magnetinio srauto tankio oro tarpe amplitudžių spektras

Fig. 3.8. Experimental resultant vector values in uncompensated post-fault condition (loss of phase F): a) resultant vector trajectory of stator currents;

b) resultant vector trajectory of magnetic flux densities in the air gap; c) resultant vector amplitude spectrum of stator currents; d) resultant vector amplitude spectrum of magnetic flux densities in the air gap 
Statoriaus srovių $\alpha-\beta$ projekcijos skaičiuojamos atitinkamai 1.4 formulei. 3.7 paveiksle pateikto atvejo vektoriai pavaizduoti 3.8 paveikslo a ir b dalyse. Poavarinio režimo metu kuriama apskritiminè srovės atstojamojo vektoriaus trajektorija yra elipsinè.

Trajektorijai vertinti taikoma greitoji Furjè transformacija. Tam būtinas laike kintantis signalas, kuriuo nurodomas atstojamojo vektoriaus ilgis - srovès $i_{\mathrm{s} \Sigma}(t)$ arba magnetinio srauto $B_{\Sigma}(t)$. Atstojamųjų vektorių trajektorijų, pavaizduotų 3.8 paveikslo a ir b dalyse, centras yra koordinačių pradžios taškas, todèl analizuojamas vektorių ilgis yra šių elipsinių trajektorijų spindulys. Gautuose atstojamųjų vektorių ilgių amplitudžių spektruose (3.8 pav. c ir d) matyti, kad trajektorijų elipsiškumas pasireiškia $100 \mathrm{~Hz}$ spektro dedamąja, t. y. pavaros maitinimo fazinio dažnio kartotiniu.

Literatūroje sutinkama mažai tiesioginio magnetinio srauto oro tarpe matavimo atvejų. Dažnai apsiribojama magnetinio srauto išskaičiavimu iš statoriaus srovių matavimų. Kartais taikoma prielaida, kad magnetinio lauko trajektorija bus elipsinè dèl elipsinės srovès vektoriaus trajektorijos. Lyginant 3.8 a ir b dalyse pateiktas trajektorijas, toks reiškinys yra mažai pastebimas.

Srovès vektoriaus 100 hercų spektro dedamosios amplitudė sudaro $15 \%$ nulinès spektro dedamosios. Atitinkamai magnetinio srauto tankio vektoriaus - tik $3 \%$.

Paklaidų ịvertinimui 3.9 paveiksle yra pateiktas normaliojo režimo atvejis. Trajektorijos turètų būti visiškai apskritiminès. Srovès vektoriaus $100 \mathrm{~Hz}$ spektro dedamosios amplitudès atitinkamas santykis - $1 \%$ ir magnetinio srauto tankio $3 \%$. Idealiu atveju šios amplitudès lygios nuliui. Šios procentinès išraiškos yra matavimų paklaidos, todèl galima teigti, kad poavarinio režimo metu magnetinio srauto tankio atstojamojo vektoriaus trajektorijos elipsiškumas nebuvo užfiksuotas.

Taip galèjo nutikti, nes magnetinis srautas magnetolaidyje pasiskirsto maždaug tolygiai, nepriklausomai nuo atjungtos statoriaus apvijos pozicijos.

Nulinio dažnio spektro dedamosios amplitudè atitinka naudingą darbą. Pavarai dirbant poavariniu režimu magnetinio srauto tankio vektoriaus ilgis sumažėjo 2 \%. Šio vektoriaus ilgio mažèjimas rodo, kad pavaros galia krito, tačiau šis kritimas yra labai mažas. Preliminarūs tyrimai, parodè, kad mechaninè charakteristika beveik nekito lyginant su normaliuoju režimu.

Taikomas neigiamų padarinių kompensavimo metodas paremtas maitinimo įtampų fazinių kampų reguliavimu (Pitrenas et al. 2017). Tuose tyrimuose daryta prielaida, kad srovés trajektorijos atstatymas yra būtinas. Nebuvo eksperimentiškai ištirta, kokị poveikị nesimetrinès statoriaus maitinimo ịtampos turi magnetinio lauko trajektorijai. Pastaroji trajektorija yra svarbesnè už statoriaus srovių sistemos trajektoriją. 
a)
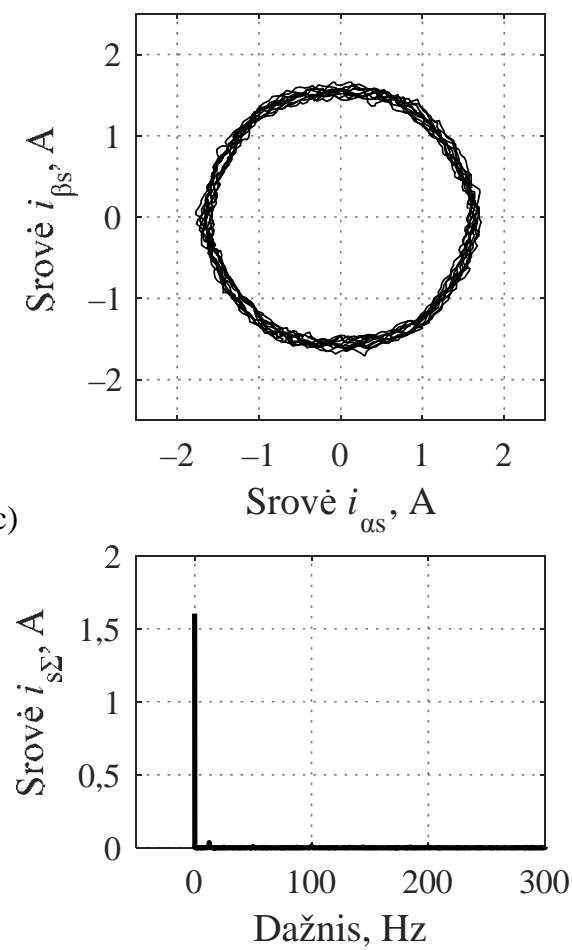

b)
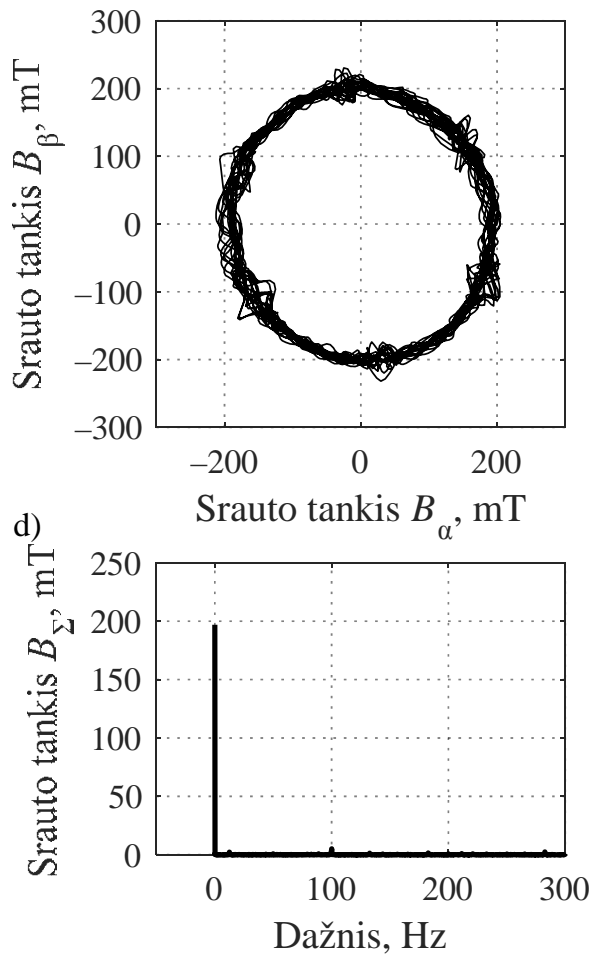

3.9 pav. Eksperimentiniai atstojamieji vektoriai normaliojo režimo metu:

a) statoriaus fazinių srovių atstojamojo vektoriaus trajektorija;

b) magnetinio srauto tankio oro tarpe trajektorija; c) statoriaus fazinių srovių atstojamojo vektoriaus amplitudžių spektras; d) magnetinio srauto tankio oro tarpe amplitudžių spektras

Fig. 3.9. Experimental resultant vector values in normal operating conditions (loss of phase F): a) resultant vector trajectory of stator currents;

b) resultant vector trajectory of magnetic flux densities in the air gap; c) resultant vector amplitude spectrum of stator currents; d) resultant vector amplitude spectrum of magnetic flux densities in the air gap

3.10 paveikslo a ir b dalyse stebimos trajektorijos yra artimos apskritiminèm. Toks rezultatas pasiektas pritaikius tokius statoriaus maitinimo ịtampų fazinius kampus: [ $2^{\circ} 61^{\circ} 115^{\circ} 179^{\circ} 243^{\circ}-$ ]. Kadangi atjungta faze F, tai šeštojo fazinio kampo skaitinè vertė yra visiškai nesvarbi. Dažninės amplitudès charakteristikos (3.10 pav. c ir d) patvirtina, kad gautas pageidaujamas rezultatas. 
a)
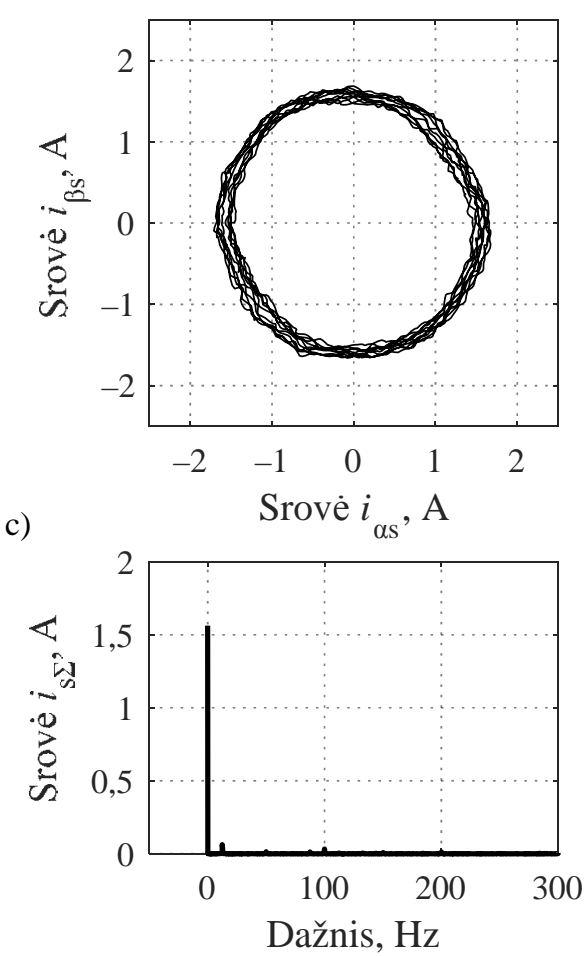

b)
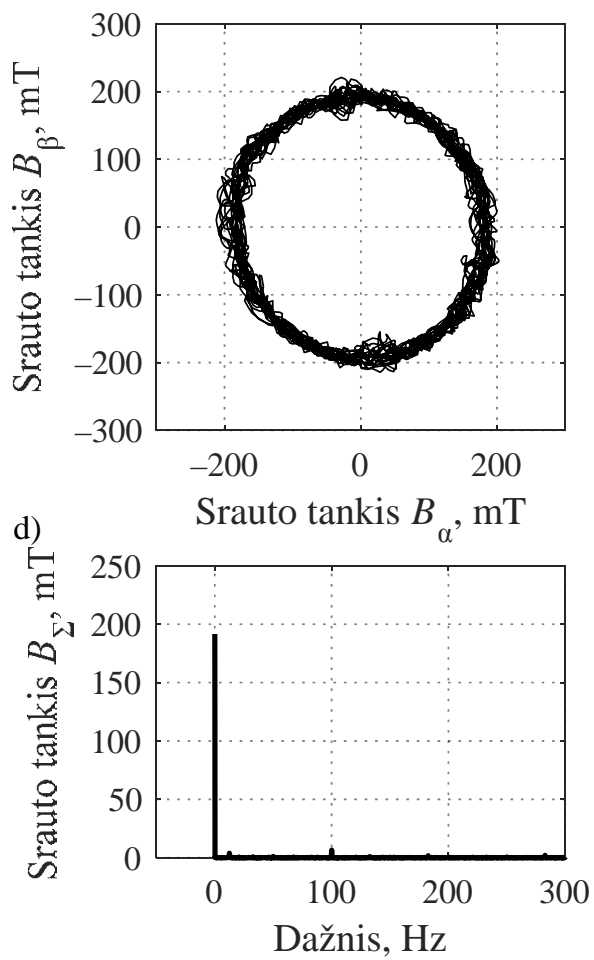

3.10 pav. Eksperimentiniai atstojamieji vektoriai kompensuojant trajektoriją poavarinio režimo metu - be F fazės: a) statoriaus fazinių srovių atstojamojo vektoriaus trajektorija; b) magnetinio srauto tankio oro tarpe trajektorija; c) statoriaus fazinių srovių atstojamojo vektoriaus amplitudžių spektras; d) magnetinio srauto tankio oro tarpe amplitudžių spektras

Fig. 3.10. Experimental resultant vector values in trajectory-compensated post-fault condition (loss of phase F): a) resultant vector trajectory of stator currents; b) resultant vector trajectory of magnetic flux densities in the air gap; c) resultant vector amplitude spectrum of stator currents; d) resultant vector amplitude spectrum of magnetic flux densities in the air gap

Pastebėta, kad statoriaus srovės atstojamojo vektoriaus apskritiminès trajektorijos atstatymui tinka daug sprendinių. Buvo prieita išvados, kad vienu metu galima atstatyti ne tik trajektoriją, o tuo pačiu sumažinti viršsrovius. Tokio bandymo rezultatai pateikti 3.11 paveiksle. Tai nėra geriausias įmanomas rezultatas, tačiau tinkamas patikrinti metodo teisingumą. Statoriaus maitinimo įtampų faziniai kampai yra: $\left[3^{\circ} 63^{\circ} 120^{\circ} 180^{\circ} 245^{\circ}-\right.$ ]. 
Pastebimas $2 \%$ magnetinio srauto tankio pagrindinès harmonikos kritimas (3.11 pav. c ir d), tačiau srauto elipsiškumas nepadidejo. Viršsrovių kompensavimas taikomu metodu neturi ženklaus šalutinio poveikio. Statoriaus maitinimo ịtampų fazinių kampų postūmiai, kurie reikalingi poavarinio režimo padariniams pašalinti, yra pakankamai maži, kad metodas nesukurtų nepageidaujamų pašalinių efektų.

a)

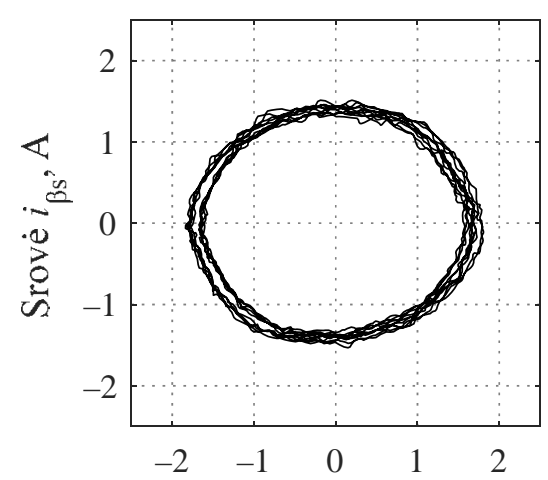

c)

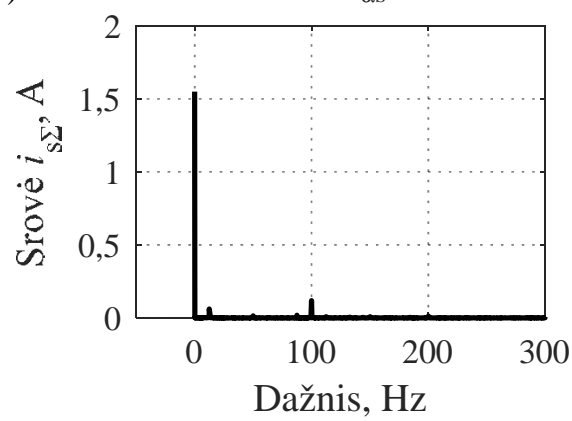

b)

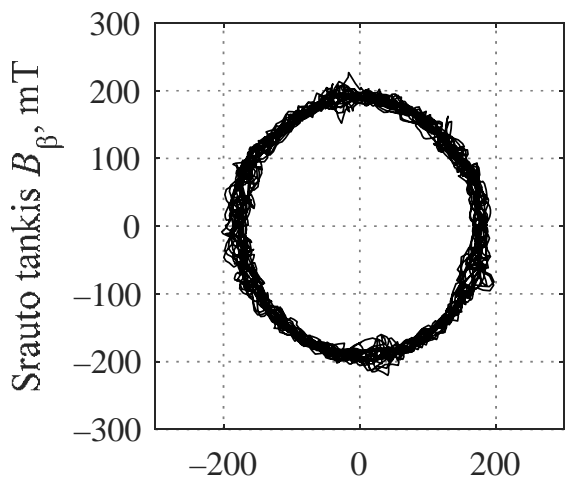

d)

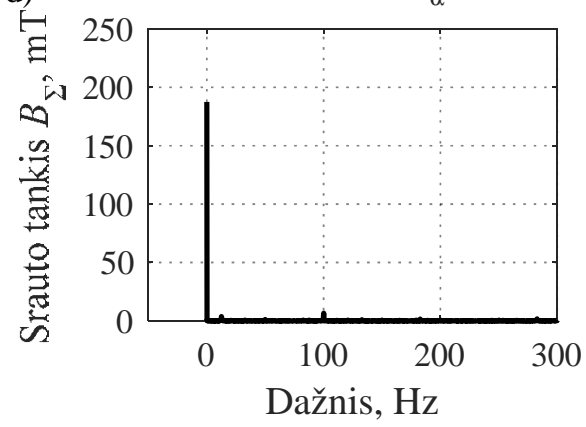

3.11 pav. Eksperimentiniai atstojamieji vektoriai kompensuojant viršsrovius poavarinio režimo metu - be F fazès: a) statoriaus fazinių srovių atstojamojo vektoriaus trajektorija; b) magnetinio srauto tankio oro tarpe trajektorija; c) statoriaus fazinių srovių atstojamojo vektoriaus amplitudžių spektras; d) magnetinio srauto tankio oro tarpe amplitudžių spektras

Fig. 3.11. Experimental resultant vector values in over-currentcompensated post-fault condition (loss of phase F): a) resultant vector trajectory of stator currents; b) resultant vector trajectory of magnetic flux densities in the air gap; c) resultant vector amplitude spectrum of stator currents; d) resultant vector amplitude spectrum of magnetic flux densities in the air gap 
a)
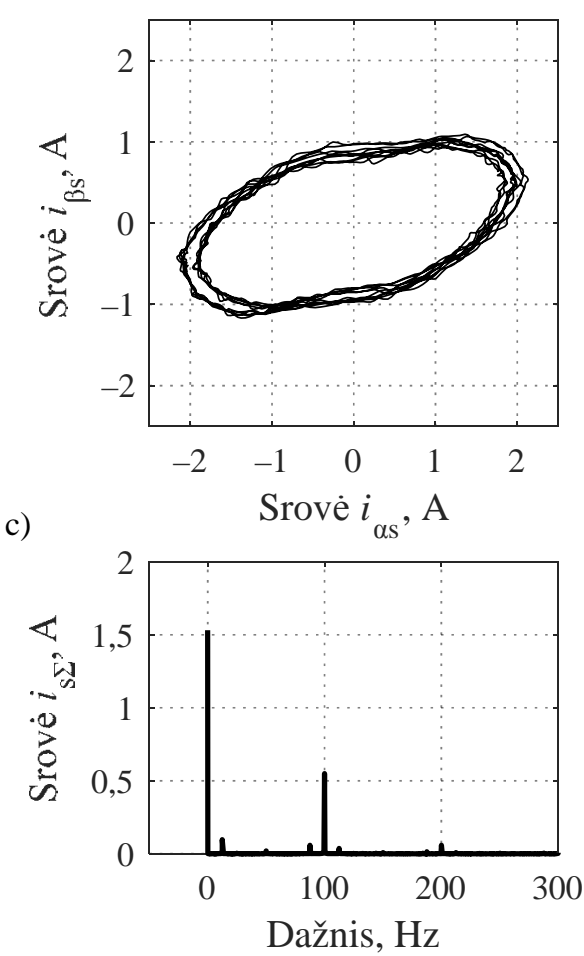

b)
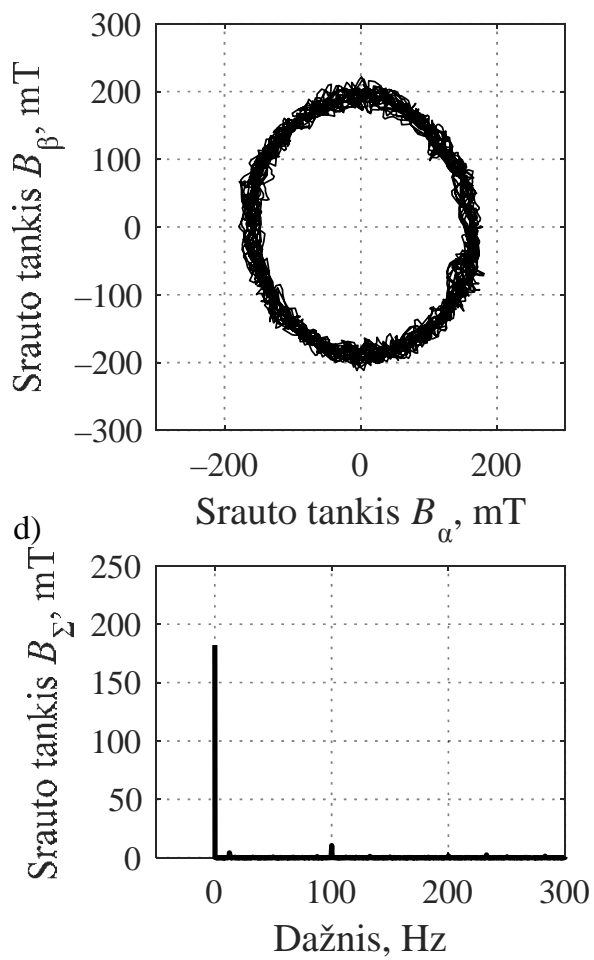

3.12 pav. Eksperimentiniai atstojamieji vektoriai nekompensuoto poavarinio režimo metu - be E ir F fazių: a) statoriaus fazinių srovių atstojamojo vektoriaus trajektorija; b) magnetinio srauto tankio oro tarpe trajektorija; c) statoriaus fazinių srovių atstojamojo vektoriaus amplitudžių spektras; d) magnetinio srauto tankio oro tarpe amplitudžių spektras

Fig. 3.12. Experimental resultant vector values in uncompensated post-fault condition (loss of phases $\mathrm{E}$ and $\mathrm{F}$ ): a) resultant vector trajectory of stator currents; b) resultant vector trajectory of magnetic flux densities in the air gap; c) resultant vector amplitude spectrum of stator currents; d) resultant vector amplitude spectrum of magnetic flux densities in the air gap

Siekiant išsiaiškinti, koki poveikị trūkstamos statoriaus fazės turi magnetiniam srautui oro tarpe, atjungtos dvi gretimos fazès. Rezultatas pateiktas 3.12 paveiksle. Matoma pati mažiausia pagrindinè amplitudė lyginant su normaliuoju režimu (3.9 pav. d) - 5 \% mažesnè, o $100 \mathrm{~Hz}$ spektro dedamosios amplitudès ir pagrindinès amplitudès santykis pats didžiausias - 6 \% (3.12 pav. d). Magnetinis laukas magnetolaidyje pasiskirstęs netolygiau. 
Statoriaus srovès atstojamojo vektoriaus ilgis (pagrindinè amplitudè, 3.12 pav. c) taip pat sumažèjęs - kritęs keturiais procentais. Tai gali būti magnetinio srauto tankių atstojamojo vektoriaus ilgio sumažèjimo priežastimi, nes vertès koreliuoja. Didžiausias šio režimo trūkumas - labai dideli viršsroviai, nes beveik nepakitusi galia (lyginant su normaliuoju režimu) pasiskirsto tarp keturių apvijų vietoje šešių.

\subsection{Poavarinio režimo kompensatoriaus sudarymo metodika}

Kompensuoti poavarinio režimo padarinius galima skaliariniu būdu, kuris nereikalauja grị̌tamųjų ryšių ir, tuo pačiu, brangių matavimo ịtaisų (Pitrènas et al. 2017). Juo galima atstatyti apskritiminę suminio statoriaus srovių vektoriaus trajektoriją ir suvienodinti pavienių statoriaus fazinių srovių efektines vertes. Taip galima pagerinti dinaminių procesų dinaminius rodiklius ir apsaugoti variklio apvijas nuo viršsrovių.

Ankstesniame poskyryje pateikiami statoriaus maitinimo įtampų faziniai kampai vienam darbo taškui, tačiau, esant daugiau kaip vienam darbo taškui ar kitokioms poavarinio režimo sąlygoms, eksperimentinis optimalių taškų radimas tampa sudètingu. Šiuo tikslu grindžiant veiksmus vektorinėmis diagramomis sudaryti eksperimentinès fazinių ịtampos kampų paieškos principai. Taikant šiame poskyryje pateiktą algoritmą galima artèti prie optimalaus sprendinio.

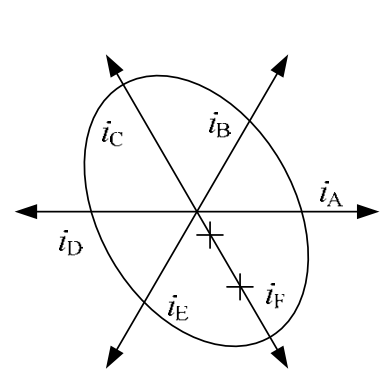

a)

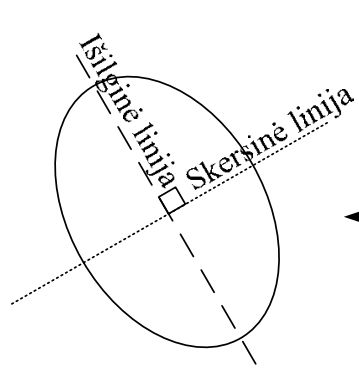

b)

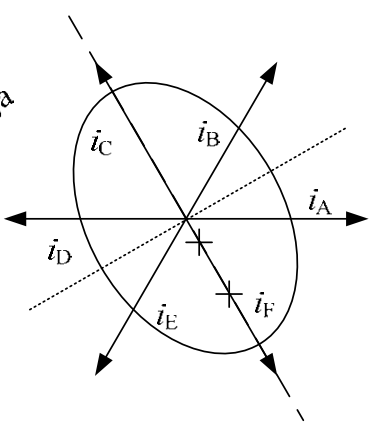

c)

3.13 pav. Statoriaus srovių suminio vektoriaus trajektorija, kai trūksta fazès F: a) susieta su statoriaus apvijų išdėstymu; b) su pagalbinèmis linijomis, žyminčiomis simetriją; c) susieta su statoriaus apvijų faziniais kampais ir su pagalbinėmis linijomis

Fig. 3.13. Trajectory of stator current resultant vector under loss of phase F:

a) fixed to stator windings distribution; b) with auxiliary lines marking symmetry; c) fixed to stator windings distribution and with auxiliary lines 
Pirmiausia, vienos fazès trūkumo poavarinio režimo metu suminio statoriaus srovių vektoriaus trajektorija tampa elipsinè, tačiau nejudama statoriaus apvijų atžvilgiu (3.13 pav. a). Šios trajektorijos elipsiškumą galima aprašyti ilgiausio ir trumpiausio spindulių santykiu, tačiau formuojant statoriaus ịtampų vektorius yra labai svarbi šios elipsès kryptis. Elipsè yra simetriška ilgiausio ir trumpiausio spindulių kryptims, kurios šiame darbe pavadintos išilgine ir skersinè linijomis (3.13 pav. b).

Galima pastebėti, kad poavarinio režimo metu suminio statoriaus srovių vektoriaus trajektorijos kryptis - išilginè linija - sutampa su trūkstamos fazès vektoriaus kryptimi (3.13 pav. c). Tai galioja visiems daugiafaziams varikliams. Šešiafazio variklio atveju, išilginè linija sutampa su vienos iš fazių vektoriumi ir skersinè linija nesutampa su jokios fazès vektoriumi. Fazinių kampų paieška kitokio fazių skaičiaus ar apvijų išdėstymo daugiafaziams varikliams aptariama poskyrio pabaigoje.

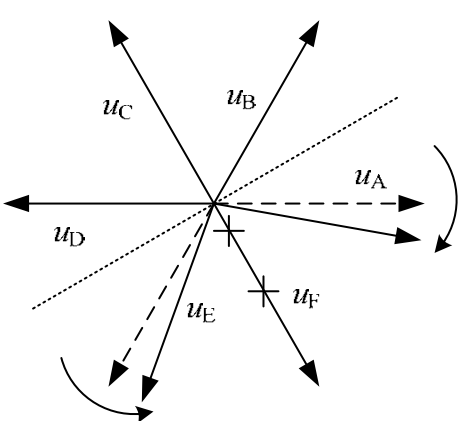

a)

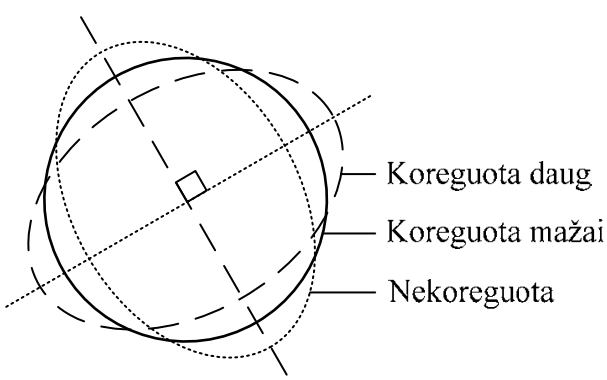

b)

3.14 pav. Statoriaus srovių suminio vektoriaus trajektorijos kompensavimas keičiant formuojamų statoriaus ịtampų fazinius kampus: a) dviejų fazinių kampų koregavimo būdas, kai dvi fazès artinamos link nutrūkusios fazès;

b) statoriaus srovių suminio vektoriaus trajektorijos prieš ir po kompensavimo

Fig. 3.14. Compensation for trajectory of stator current resultant vector by means of shifting generated stator voltage phase angles: a) approach by shifting of two phase angles closer to the lost phase; b) trajectories of stator current resultant vector before and after compensation

Vadovaujantis publikacija (Pitrėnas et al. 2017), eksperimentiškai nustatyta, kad suminio statoriaus fazinių srovių vektoriaus trajektorijos elipsiškumas priklauso nuo formuojamų statoriaus ịtampų fazinius kampus. Paprasčiausias būdas 
pavaizduoti ši kompensavimo principą yra braižant formuojamų statoriaus įtampos vektorių diagramą. 3.14 paveikslo a dalyje yra sužymèti statoriaus įtampų faziniai vektoriai, pažymèta trūkstama statoriaus fazė ir skersinè simetrijos linija. Taip pat 3.14 paveikslo a dalyje yra pažymètos formuojamų statoriaus įtampų fazinių kampų postūmių kryptys.

Keičiant formuojamų statoriaus ịtampų fazinių kampus kaip nurodyta 3.14 paveikslo a dalyje, gaunamas poveikis pavaizduotas 3.14 paveikslo b dalyje. Su fazinių kampų poslinkiu, kuris yra mažesnis nei 10 elektrinių laipsnių, eksperimentiškai gautos suminio statoriaus fazinių srovių vektoriaus trajektorijos, kurių dalis yra artimos apskritiminei ir dalis yra elipsinès, bet priešingos krypties nei nekompensuoto režimo atveju.

Suminio statoriaus fazinių srovių vektoriaus trajektorijos atstatymo ị apskritiminę uždavinys turi daug sprendinių - yra labai didelis formuojamų statoriaus įtampų fazinių kampų poslinkių kombinacijų, duodančių tinkamą rezultatą. 3.14 paveiksle a dalyje pateiktas sprendinio paieškos būdas yra ne vienintelis, nes jame keičiami tik du faziniai kampai, tų fazių, kurios yra arčiausiai trūkstamos fazès. Identišką poveikị trajektorijai galima išgauti artinant kitus formuojamos ịtampos vektorius link išilginès linijos, taip kaip pateikta 3.15 paveiksle.

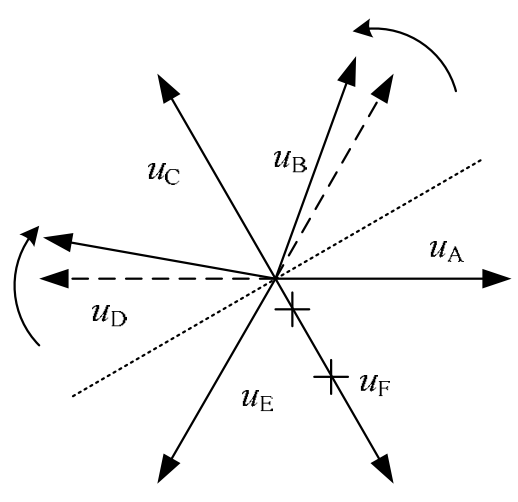

a)

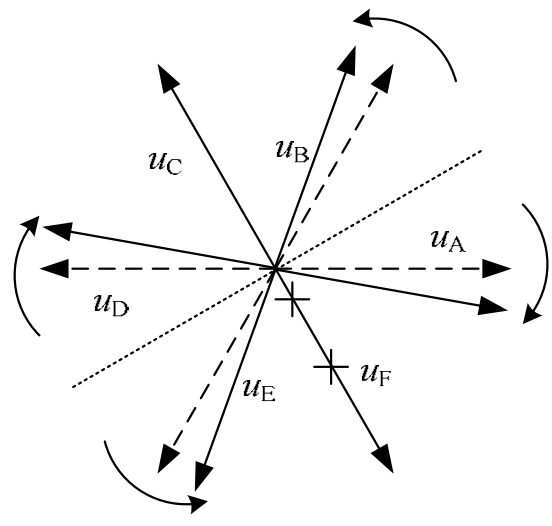

b)

3.15 pav. Statoriaus srovių suminio vektoriaus trajektorijos kompensavimas keičiant formuojamų statoriaus ịtampų fazinius kampus: a) dviejų fazinių kampų koregavimo būdas, kai dvi fazès artinamos link priešingos krypties nei nutrūkusios fazès; b) daugelio fazinių kampų koregavimo būdas

Fig. 3.15. Compensation for trajectory of stator current resultant vector by means of shifting generated stator voltage phase angles: a) approach by shifting of two phase angles closer to the opposite direction of the lost phase; b) approach by shifting of multiple phase angles 
Kompensuojant suminio statoriaus fazinių srovių vektoriaus trajektoriją reikia laikytis simetrijos parenkant fazinių kampu poslinkius (3.14 pav. a ir 3.15 pav.). Naudojamas eksperimentinis tyrimų stendas leidžia keisti fazinius kampus po 1 laipsnį. Tokiu atveju tikslinga keisti visus reikiamus kampus vienodais poslinkiais - po 1 laipsnị. Nesilaikant tokio reikalavimo, trajektorijos nubrèžta elipsè keis kryptị ir nebesutaps su simetrijos linijomis. Tokị variantą gali pavykti sukompensuoti taikant sudètingesnes fazinių kampų poslinkių kombinacijas, tačiau tai apsunkintų paiešką. Tikslingiau paprastesnị būdą kartoti, kol trajektorija atstatoma ị apskritiminę.

Poslinkiai turi būti taikomi fazèms, kurios yra skirtingose išilginèse pusėse, tačiau tose pačiose skersinès simetrijos linijos pusėse (3.14 pav. a ir 3.15 pav.). Taip išlaikoma simetrija ir išvengiama tokių pačių sudètingų situacijų, kurios gaunamos taikant skirtingas poslinkių vertes.

Apskritiminè suminio statoriaus fazinių srovių vektoriaus trajektorija nereiškia simetriško fazinių srovių pasiskirstymo. Viena ar daugiau fazių gali būti stipriai išaugusios ir todèl gali susidaryti viršsroviai. Kompensuojant tik trajektoriją, ši vertė gali dar labiau išaugti. Tokiu tikslu formuojamos statoriaus ịtampos fazinių kampų optimalumo kriterijus yra sudarytas iš dviejų reikalavimų: apskritiminés trajektorijos ir vienodų efektinių verčių.

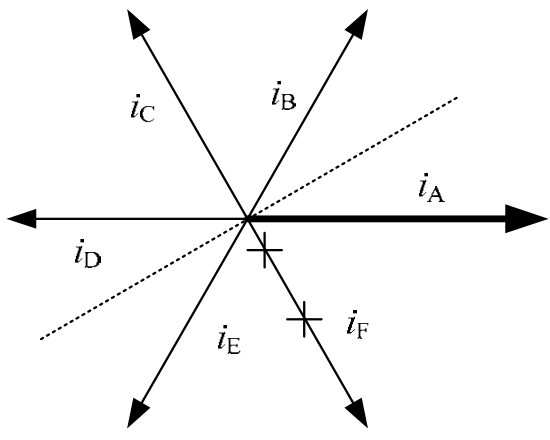

a)

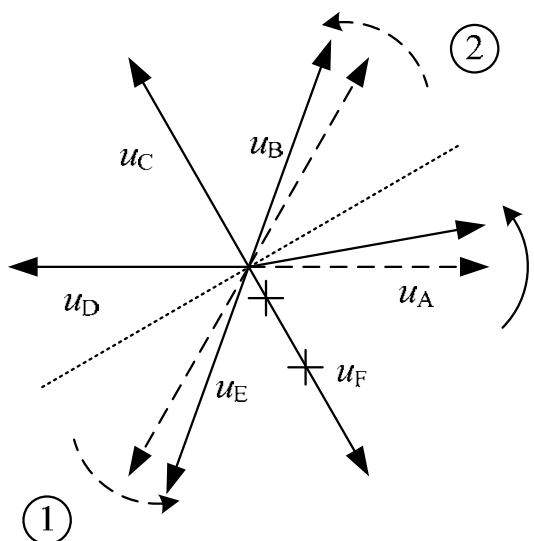

b)

3.16 pav. Nevienodų statoriaus srovių efektinių verčiu kompensavimas

keičiant formuojamų statoriaus įtampų fazinius kampus:

a) nekompensuotos srovių amplitudès; b) ịtampų fazinių kampų postūmiai

Fig. 3.16. Compensation for unequal effective values of stator currents by means of shifting generated stator voltage phase angles: a) uncompensated phase current amplitudes; b) voltage phase angles shift 
Kompensuoti išaugusias statoriaus fazinių srovių efektines vertes tikslingiausia po apskritiminès suminio statoriaus fazinių srovių vektoriaus trajektorijos atstatymo. 3.16 paveikslo b dalyje pateiktas būdas keičia srovių efektines vertes (3.16 pav. a) beveik neįtakodamas trajektorijos. Skaičiais pažymèti du galimi variantai abu turi panašų poveikị mažinamai fazinei srovei. Tačiau čia galima parinkti, kuri srovė bus didinama. Kartojant ši veiksmą, srovès po kelių iteracijų yra suvienodinamos sukuriant mažą poveikị trajektorijai.

Taikant statoriaus fazinių srovių efektinių verčių būdą kitoms fazėms nei pateikta 3.16 paveikslo b dalyje, reikia laikytis simetrijos linijų. Galimi variantai yra simetriški išilginei arba skersinei simetrijos linijai. Taip šešiafazio variklio poavarinio režimo atveju kompensuojamos keturios iš penkių fazių.

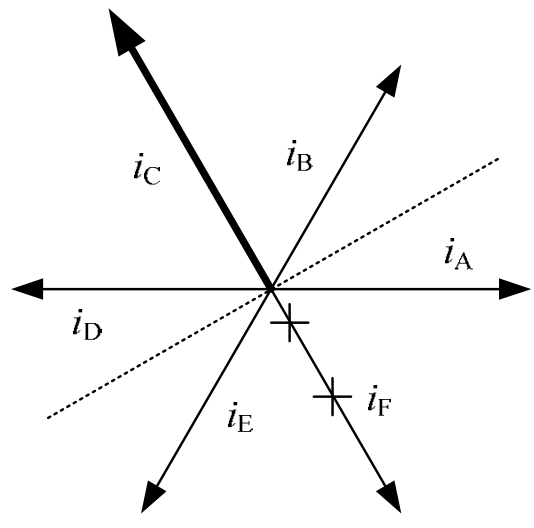

a)

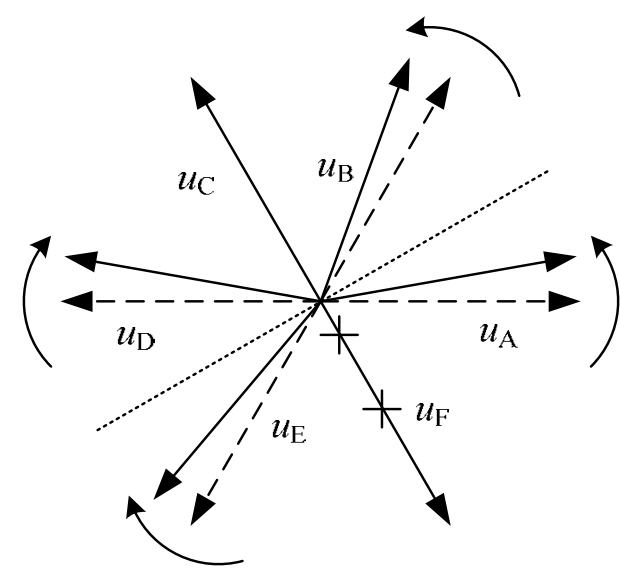

b)

3.17 pav. Nevienodų statoriaus srovių efektinių verčių kompensavimas keičiant formuojamų statoriaus įtampų fazinius kampus, kai kompensuojama statoriaus srové, kurios vektoriaus kryptis sutampa su išilgine simetrijos linija: a) nekompensuotos srovių amplitudès; b) ịtampu fazinių kampų postūmiai

Fig. 3.17. Compensation for unequal effective values of stator currents by means of shifting generated stator voltage phase angles when the compensated stator current's vector direction matches the longitudinal symmetry line: a) uncompensated phase current amplitudes; b) voltage phase angles shift

Likusi fazès padètis yra visiškai priešinga trūkstamai fazei (3.17 pav. a), todèl keisti jos ịtampos fazinị kampą yra netikslinga - išilginè simetrijos linija ir vektorius ant jos yra atskaitos taškas. Toks atvejis sprendžiamas kitu būdu, pateiktu 
3.17 paveiksle b dalyje. Visus ịtampos fazinius kampus pasukant link kompensuojamos fazės vektoriaus, ši srovè sumažinama ir padidinamos visos likusios. Artinant mažiau nei keturis vektorius, pakistų suminio statoriaus fazinių srovių vektoriaus trajektorija.

Šie eksperimentinės paieškos principai reikalingi siekiant sumažinti iteracijų skaičių ieškant sprendinių. Dèl techninių sunkumų nèra galimybės atlikti dešimčių ar šimtų bandymų kiekvienam pasirinktam darbo taškui per priimtiną laiką. Tai ịtakoja pereinamųjų procesų trukmè, techninès ịrangos pažangumas. Universalūs paieškos metodai, tokie kaip simpleksinis paieškos metodas, reikalautų daug iteracijų siekiant gauti rezultatą identišką 3.11 paveiksle pateiktam atvejui. Todèl verta taikyti ekspertines žinias.

Statoriaus maitinimo ịtampų fazinių kampų eksperimentinès paieškos rezultatai pateikti 3.2 lentelëje.

3.2 lentelė. Eksperimentinės fazinių kampų paieškos rezultatai

Table 3.2. Experimental results of phase angle search

\begin{tabular}{|l|l|l|l|l|}
\hline Nr. & Maitinimo ịtampu faziniai kampai & Elipsiškumas & $\begin{array}{l}\text { Didžiausios } \\
\text { srovès } \\
\text { amplitudè, A }\end{array}$ & $\begin{array}{l}\text { Tikslo } \\
\text { funkcijos } \\
\text { rezultatas }\end{array}$ \\
\hline 1 & {$\left[0^{\circ} 60^{\circ} 119^{\circ} 180^{\circ} 241^{\circ}-\right]$} & 0,277 & 2,285 & 1,300 \\
\hline 2 & {$\left[0^{\circ} 60^{\circ} 118^{\circ} 180^{\circ} 242^{\circ}-\right]$} & 0,255 & 2,277 & 1,245 \\
\hline 3 & {$\left[0^{\circ} 60^{\circ} 117^{\circ} 180^{\circ} 243^{\circ}-\right]$} & 0,238 & 2,290 & 1,235 \\
\hline 4 & {$\left[0^{\circ} 60^{\circ} 116^{\circ} 180^{\circ} 244^{\circ}-\right]$} & 0,229 & 2,309 & 1,307 \\
\hline 5 & {$\left[1^{\circ} 60^{\circ} 115^{\circ} 180^{\circ} 244^{\circ}-\right]$} & 0,216 & 2,359 & 1,440 \\
\hline 6 & {$\left[2^{\circ} 60^{\circ} 115^{\circ} 180^{\circ} 243^{\circ}-\right]$} & 0,161 & 2,945 & 1,545 \\
\hline 7 & {$\left[2^{\circ} 61^{\circ} 115^{\circ} 179^{\circ} 243^{\circ}-\right]$} & 0,090 & 2,891 & 1,391 \\
\hline 8 & {$\left[2^{\circ} 61^{\circ} 115^{\circ} 178^{\circ} 242^{\circ}-\right]$} & 0,040 & 2,787 & 1,346 \\
\hline 9 & {$\left[2^{\circ} 61^{\circ} 115^{\circ} 177^{\circ} 241^{\circ}-\right]$} & 0,067 & 2,670 & 1,085 \\
\hline 10 & {$\left[1^{\circ} 60^{\circ} 115^{\circ} 177^{\circ} 241^{\circ}-\right]$} & 0,072 & 2,522 & 1,134 \\
\hline 11 & {$\left[0^{\circ} 59^{\circ} 115^{\circ} 177^{\circ} 241^{\circ}-\right]$} & 0,082 & 2,517 & 1,062 \\
\hline 12 & {$\left[-1^{\circ} 58^{\circ} 115^{\circ} 177^{\circ} 241^{\circ}-\right]$} & 0,105 & 2,496 & 0,982 \\
\hline 13 & {$\left[-2^{\circ} 58^{\circ} 115^{\circ} 176^{\circ} 241^{\circ}-\right]$} & 0,119 & 2,461 & 0,965 \\
\hline 14 & {$\left[-2^{\circ} 58^{\circ} 115^{\circ} 175^{\circ} 240^{\circ}-\right]$} & 0,138 & 2,436 & 0,925 \\
\hline & & & & \\
\hline
\end{tabular}


Taikant šiame poskyryje nurodytus maitinimo įtampų fazinių kampų koregavimo veiksmus buvo rasti parametrai, kuriais atstatytos srovių atstojamojo vektoriaus trajektorijos (3.10 pav. a) ir sumažinti viršsroviai (3.11 pav. a). Atliktos paieškos iteracijos yra pateiktos 3.2 lentelèje.

Atstatytos trajektorijos atveju (3.2 lentelè, 7 iteracija) statoriaus srovių atstojamojo vektoriaus trajektorijos elipsiškumas siekia tik 4 \%. Normaliojo režimo atveju gautas 3,6 \% elipsiškumas. Ivertinus matavimo paklaidas, galima teigti, kad trajektorijos nesiskiria. Elipsiškumas apskaičiuotas taip:

$$
e=1-\frac{b}{a},
$$

čia $b$ - trumpasis elipsès spindulys, $a$-ilgasis elipsès spindulys.

3.2 lentelèje pateikiamas ir tikslo funkcijos rezultatas. Atliekant paiešką reikalingas rodiklis nusakantis, ar gauti parametrai pagerina valdomus procesus. Kadangi siekiama atstatyti vektoriaus apskritiminę trajektoriją ir sumažinti viršsrovius, sukurta tikslo funkcija yra:

$$
\begin{aligned}
& f\left(e, I_{\mathrm{A}}, I_{\mathrm{B}}, I_{\mathrm{C}}, I_{\mathrm{D}}, I_{\mathrm{E}}\right)= \\
& e+k \cdot \frac{\sigma\left(I_{\mathrm{A}}, I_{\mathrm{B}}, I_{\mathrm{C}}, I_{\mathrm{D}}, I_{\mathrm{E}}\right)}{I_{\text {vid. }}}+\left(\frac{I_{\text {norm.r. }}-I_{\text {vid. }}}{I_{\text {norm.r. }}}\right)^{2},
\end{aligned}
$$

čia $\sigma$ - standartinè nuokrypa, $I_{\mathrm{A}-\mathrm{E}}$ - fazinių srovių amplitudès, $I_{\text {vid. }}$ - fazinių srovių vidurkis, $I_{\text {norm.r. }}$ - normaliojo režimo fazinių srovių amplitudžių vidurkis, $k$ - viršsrovių kompensavimo svoris lygus 5.

Siekiant tikslo funkciją taikyti bet kokių parametrų varikliui, visi tikslo funkcijos nariai išreikšti santykiniais dydžiais, įskaitant standartinę nuokrypą. Užtikrinus, kad visų statoriaus srovių amplitudès yra lygios (standartinei paklaidai artẻjant link nulio), gaunami mažiausi įmanomi viršsroviai. Sudaryta tikslo funkcija yra minimizavimo funkcija.

Jei paieškai būtų taikoma automatinė paieška ir tarpiniai rezultatai nėra validuojami, galima susidurti su situacija, kai dèl didelių fazinių kampų postūmių atstojamojo įtampų vektoriaus ilgis stipriai sumažètų ir tai reikštu galios kritimą. Todèl paskutinysis tikslo funkcijos narys yra santykinès paklaidos kvadratas, užtikrinantis, kad statoriaus srovių atstojamojo vektoriaus ilgis išliktų artimas normaliojo režimo vektoriaus ilgiui.

Tikslo funkciją sudaro trys nariai, kurių itaka nėra vienoda. Pirmojo ir antrojo narių reikšmingumas suvienodintas įvedus svorị $k$, t. y. vertinant nekompensuotą vienos nutrūkusios statoriaus fazès poavarinị režimą šie nariai yra apytikriai lygūs. Apskritiminès trajektorijos ir mažiausių viršsrovių užtikrinimas yra vienodai svarbai. Iprastai trečiojo nario vertė yra pati mažiausias, tačiau viršytų likusius 
narius, jei statoriaus srovių vidurkis lyginant su normaliuoju režimu kristų 30 \% arba daugiau.

Atlikus fazinių kampų paiešką, maksimalią statoriaus srovių pagrindinės harmoniką pavyko sumažinti 9 \% lyginant su nekompensuotu vienos trūkstamos fazès poavarinio režimo atveju. Šis rezultatas yra sąlyginis ir gali būti svarbus priklausomai nuo pavaros konstrukcijos, pavyzdžiui, apvijų izoliacijos.

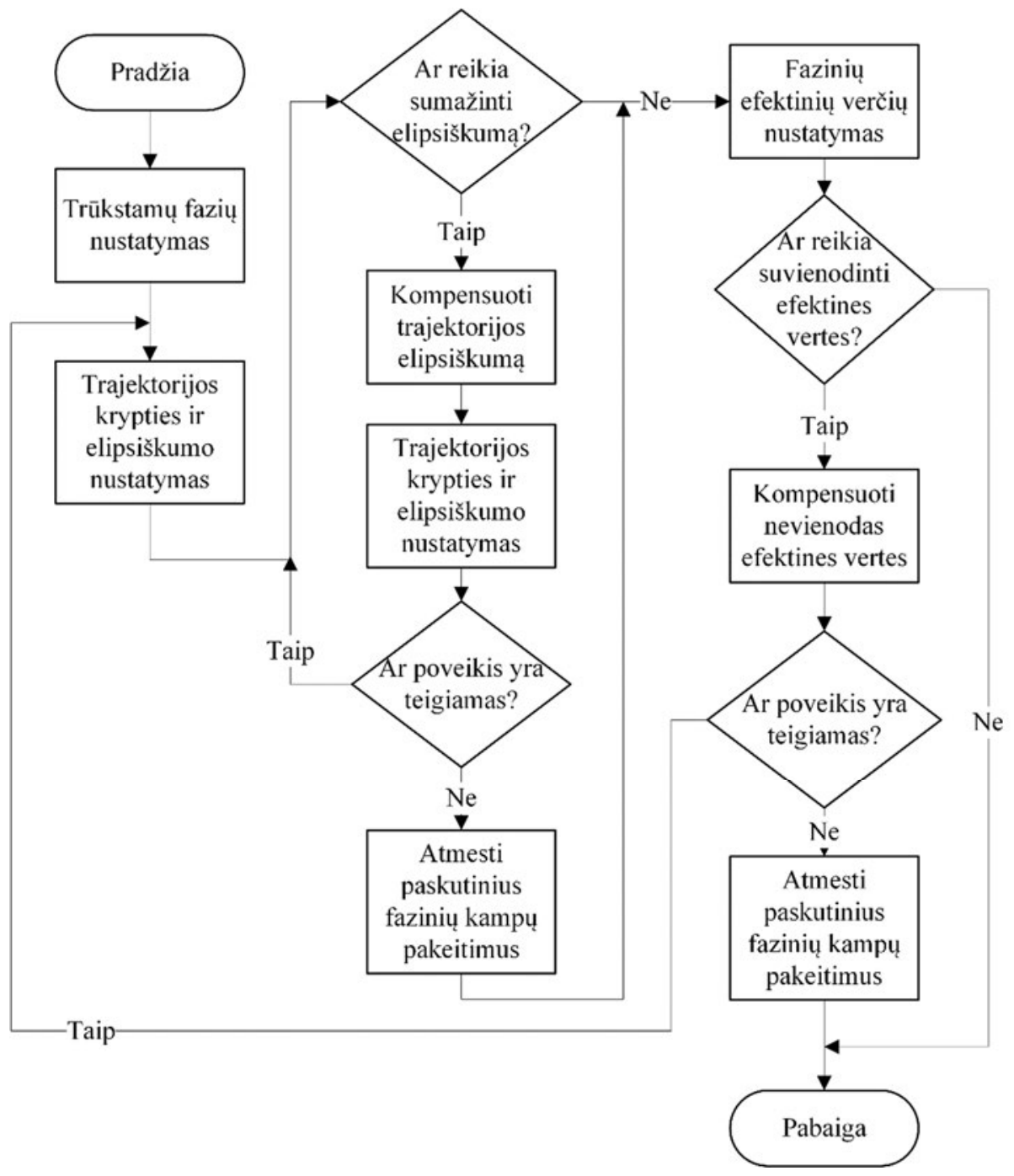

3.18 pav. Statoriaus įtampos fazinių kampų paieškos algoritmas

Fig. 3.18. Search algorithm for stator voltage phase angles 
Šis viršsrovių kompensavimo būdas būtų labai efektyvus poavariniuose režimuose, kuriuose trūksta daugiau nei vienos fazès. Pavyzdžiui, trūkstant dviejų gretimų fazių, viena iš srovių išaugo 126 \% lyginant su normaliuoju režimu. Teoriškai šią vertę pavyktų sumažinti iki 50 \%.

Bendru atveju galima laikytis tokios tvarkos: atstatyti trajektoriją, tada vienodinti sroves, vèliau patikrinti, ar nesugadinta trajektorija, ir esant poreikiui ciklą pakartoti. Smulkiau procesas išdėstytas 3.18 paveiksle - paieškos algoritme.

Dèl dažnio keitiklio valdymo programos ypatumų, maitinimo įtampų kampai keičiami vieno pilno laipsnio žingsniais. Tai sumažina iteracijų skaičių, bet tuo pačiu ir rezultato optimalumą.

Siekiant šiuos poavarinio režimo padarinių kompensavimo principus taikyti praktiškai, neužtenka pritaikyti vieno sprendinio. Skirtingomis sąlygomis gaunami skirtingi sprendiniai tai pačiai pavarai. Pavyzdžiui, valdant greitị rastas sprendinys nebetiks. Reiktų taikyti reguliatorių, kuris keistų maitinimo įtampų fazinius kampus dinamiškai.

Jei užtenka reguliavimo pagal vieną kintamajji, visiškai pakaktų verčių parinkimo lentelès (angl. look-up table). Jei ịvertinama daugiau dydžių, pavyzdžiui, apkrovos srovė ar įtampos krytis, tokia priemonè jau nebetenkintų poreikių.

Siūlomas sprendimas yra neraiškiosios logikos reguliatorius.

Neraiškiosios logikos reguliatoriui sudaryti naudotas Matlab programinis paketas Fuzzy Logic Toolbox, kuris siūlo Mamdani ir Sugeno tipo reguliatorius. Kadangi ekspertinès žinios apie sistemą apsiribotų eksperimentiškai gautais paieškos sprendiniais, taikomas Sugeno reguliatoriaus tipas.

Kartu su reguliatoriaus karkasu pateiktas ir automatinis apmokymo įrankis. Suvedus visus skirtingiems darbo taškams rastus sprendinius kaip apmokymo duomenis ir pasirinkus ịejjimo ir išẻjimo signalų struktūrą, automatiškai sudaromos visos lingvistinès taisyklès, bei priskiriamos vertės pasirinktai struktūrai.

Šešiafazès elektros pavaros poavarinio režimo padarinių kompensavimo sistemos su neraiškiosios logikos reguliatoriumi funkcinè schema pateikta 3.19 paveiksle.

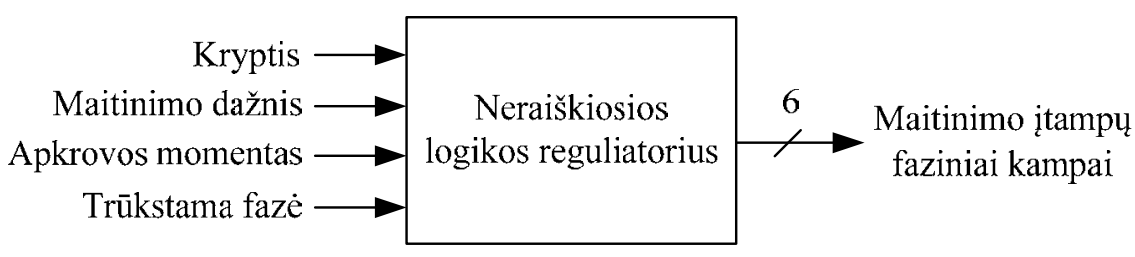

3.19 pav. Poavarinio režimo kompensatoriaus funkcinè schema

Fig. 3.19. Functional block diagram of post-fault condition compensator 
Dèl paprastumo apsiribota tokiais įejjimo signalais: variklio rotoriaus sukimosi kryptimi, statoriaus maitinimo ịtampų faziniu dažniu, apkrovos momentu ir trūkstama faze (3.19 pav.). Kadangi tiriama skaliarinè U/f valdymo pavara, tai dažnio keitimas prilygsta greičio reguliavimui.

Jei vertinama, kad nutrūkusi fazè $\mathrm{F}$, užtenka keturių fazinių kampų reguliatoriui apmokyti. Maitinimo ịtampų fazinių kampų parinkimo lentelè (3.3 lentelė) sudaryta simetriškai, tačiau tai galioja ne visais atvejais. Pavyzdžiui, kai kurie varikliai yra suprojektuoti suktis viena kryptimi (kitokia statoriaus ir/ar rotoriaus griovelių konstrukcija).

Laikoma, kad variklis yra simetriškas, todèl vadovaujantis 3.3 lentele užpildyta visa apmokymo duomenų lentelè. Joje numatyti atvejai kai trūksta kitos fazės nei F. Galutinis rezultatas - 48 ịejjimo signalų rinkiniai kiekvienam iš išèjimo signalų.

3.3 lentelè. Maitinimo įtampų fazinių kampų parinkimo lentelè, kai fazė $F$ yra atvira

Table 3.3. Source voltage phase angle selection table when stator phase F is open

\begin{tabular}{|l|l|l|l|l|l|l|l|l|}
\cline { 4 - 9 } \multicolumn{2}{c}{} & \multicolumn{6}{|c|}{ Maitinimo itampu faziniai kampai, } \\
\hline Kryptis & $\begin{array}{l}\text { Maitinimo } \\
\text { dažnis, Hz }\end{array}$ & $\begin{array}{l}\text { Apkrovos } \\
\text { momentas, N·m }\end{array}$ & A & B & C & D & E & F \\
\hline Pirmyn & 50 & 0,5 & 3 & 63 & 120 & 180 & 245 & 300 \\
\hline Pirmyn & 50 & 2,5 & 3 & 64 & 120 & 178 & 244 & 300 \\
\hline Pirmyn & 30 & 0,5 & 2 & 62 & 120 & 180 & 244 & 300 \\
\hline Pirmyn & 30 & 2,5 & 2 & 63 & 120 & 178 & 243 & 300 \\
\hline Atgal & 30 & 0,5 & 356 & 60 & 120 & 178 & 238 & 300 \\
\hline Atgal & 30 & 2,5 & 357 & 62 & 120 & 177 & 238 & 300 \\
\hline Atgal & 50 & 0,5 & 355 & 60 & 120 & 177 & 237 & 300 \\
\hline Atgal & 50 & 2,5 & 356 & 62 & 120 & 176 & 237 & 300 \\
\hline
\end{tabular}

Taikant programinius Fuzzy Logic Toolbox įrankius apmokomas neraiškiosios logikos reguliatorius. Jis užtikrintų, kad visame numatytame įejjimo signalų diapazone reguliatorius išduotų reikšmes artimas optimalioms.

3.20 paveiksle pateikta vieno iš išèjimo signalų priklausomybè nuo maitinimo dažnio ir apkrovos momento. Matyti, kad pavaizduotame paviršiuje nèra trūkio taškų, o vertės priimtinos visame numatytame dažnių diapazone nuo 30 iki $50 \mathrm{~Hz}$. 


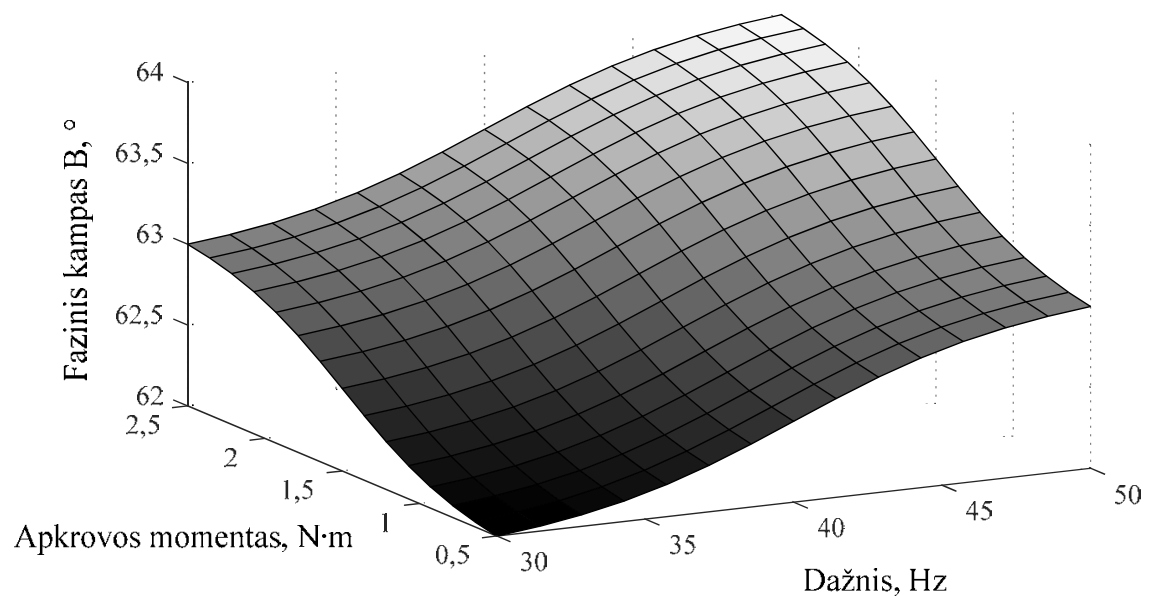

3.20 pav. Kompensatoriaus fazinio kampo B išèjimo priklausomybių paviršius

Fig. 3.20. Compensator surface of phase angle B output membership functions

Dèl neraiškiosios logikos reguliatorių ypatumų, yra įvairių galimybių nesudètingai pakoreguoti esamą rezultatą:

- pakeisti ịejimo ir išẻjimo signalų struktūrą apmokymo metu;

- papildyti apmokymo duomenų lentelę naujais sprendiniais ir pakartotinai apmokinti reguliatorių;

- taikyti ekspertines žinias patikslinti priklausomybių funkcijų koeficientus tiesiogiai.

Naudotas keitiklis turi vieno laipsnio valdymo signalo žingsni, todèl kompensatorius turi kvantuoti išèjimo signalus.

\subsection{Trečiojo skyriaus išvados}

1. Nustatyta, kad magnetinio srauto tankių atstojamojo vektoriaus trajektorija yra artima apskritiminei. Tokie rezultatai gauti ne tik normaliojo, bet ir poavarinio režimų metu, kai atjungta viena ar dvi gretimos šešiafazio variklio statoriaus fazès. 
2. Sukurti fazinių kampų paieškos principai ir paieškinis algoritmas, skirti statoriaus srovių atstojamojo vektoriaus trajektorijos kompensavimui ir statoriaus viršsrovių sumažinimui keičiant formuojamas statoriaus įtampas.

3. Taikant vektorinėmis diagramomis pagrịstus eksperimentinès paieškos principus pavyko atstatyti visiškai apskritiminę statoriaus srovių atstojamojo vektoriaus trajektoriją - tokią kaip veikiant normaliuoju režimu.

4. Pagal paieškos algoritmą atlikus keturiolika iteracijų, viršsroviai sumažinti 9 \%. Plačiai taikomos simpleksinès paieškos atveju, iteraciju skaičius būtų daug didesnis, o penkių kintamụjų uždavinys gali būti neišsprendžiamas. 



\section{Bendrosios išvados}

1. Sukurtas neraiškiosios logikos reguliatorius vektoriniam tiesioginio momento valdymo būdui, kuris pakeičia histerezès kilpos reguliatorius bei ịtampos vektorių parinkimo lentelę ir pagerina daugiafazès pavaros dinamines charakteristikas lyginant su tipiniu tiesioginio momento valdymu.

2. Pritaikius neraiškiają logiką tiesioginio momento valdymo pavarai, išspręstas pradinio magnetinio lauko kūrimo klausimas ir tuo pačiu apribotos magnetinio lauko nuokrypos.

3. Tiesioginis momento valdymas su neraiškiosios logikos reguliatoriumi pagerino dinaminius rodiklius lyginant su tipiniu tiesioginio momento valdymo atveju - sumažino elektromagnetinio momento pulsacijas $26 \%$, o statoriaus magnetinio srauto - $26 \%$, kai užduotas mažas magnetinio srauto nuostatis $(0,7 \mathrm{~Wb})$. Uždavus didelę nuostačio vertę (2,1 Wb), elektromagnetinio momento pulsacijos sumažintos $8 \%$, o statoriaus magnetinio srauto - $35 \%$.

4. Nustatyta, kad magnetinio srauto tankių oro tarpe atstojamojo vektoriaus trajektorija yra artima apskritiminei. Tokie eksperimentiniai rezultatai gauti ne tik normaliojo, bet ir poavarinio režimų metu, kai atjungta viena ar dvi gretimos šešiafazio variklio statoriaus fazès. 
5. Taikant statoriaus srovių ir ịtampų vektorinėmis diagramomis pagrịstus paieškos principus pavyko atstatyti apskritiminę statoriaus srovių atstojamojo vektoriaus trajektoriją - tokią kaip normaliuoju režimu.

6. Pagal paieškos algoritmą atlikus keturiolika iteracijų, viršsroviai sumažinti 9 \%. Plačiai taikomos simpleksinès paieškos atveju, iteracijų skaičius būtų daug didesnis, o penkių kintamųjų uždavinys gali būti neišsprendžiamas.

7. Sukurta neraiškiosios logikos reguliatoriaus sudarymo metodika statoriaus viršsrovių ir srovių atstojamojo vektoriaus trajektorijos kompensavimui įvairiuose darbo taškuose poavarinio režimo metu, kai trūksta vienos ar daugiau statoriaus fazių. 


\section{Literatūra ir šaltiniai}

Abbas, M. A.; Christen, R.; Jahns, T.M. 1984. Six-phase voltage source inverter driven induction motor, IEEE Transactions on Industry Applications 20(5): 1251-1259.

Abdel-Khalik, S.; Elgenedy, M. A.; Ahmed, S.; Massoud, A. M. 2016. An improved faulttolerant five-phase induction machine using a combined star/pentagon single layer stator winding connection, IEEE Transactions on Industry Applications 63(1): 618-628.

Abjadi, A. R.; Markadeh, G. A.; Soltani, J. 2010. Model following sliding-mode control of a six-phase induction motor drive, Journal of Power Electronics 10(6): 649-701.

Abu-Rub, H.; Iqbal, A.; Guzinski, J. 2012. High Performance Control of AC Drives with Matlab/Simulink Models. United Kingdom: John Wiley \& Sons Ltd. 492 p. ISBN 978-0470-97829-0.

Ahmed, S. M. 2012. Model predictive current control of a quasi sixphase voltage source inverter, in IEEE International Symposium on Industrial Electronics ISIE, Hangzhou, China, 2012. 2036-2041.

Alnajjar, M.; Gerling, D. 2015. Model predictive control of six-phase variable frequency electrically excited starter generator for more electric aircraft, in IEEE 11th International Conference on Power Electronics and Drive Systems PEDS, Sydney, NSW, Australia. 2328.

Andrese, E.; Bieniek, K. 1981. 6-phase induction motors for current-source inverter drives, in Proc. IEEE Industry Applications Society Annual Meeting IAS, Philadelphia, PA, 1981: 607-618. 
Archana N.; Chudasama A. R. 2012. Control of designed developed six-phase induction motor, International Journal of Electromagnetics and Applications 2(5): 77-84.

Baltatanu, A.; Florea, M. L. 2013. Multiphase machines used in electric vehicles propulsion, in International Conference on Electronics, Computers and Artificial Intelligence ECAI, Pitesti, Romania, 2013: 1-6.

Barrero, F.; Duran, M. J. 2016. Recent advances in the design, modeling and control of multiphase machines-Part 1, IEEE Transactions on Industrial Electronics 63(1): 449458.

Baškys, A.; Bleizgys, V.; Lipinskis, T. 2011. An analysis of the inverter overvoltage generated by the motor, Electrical review 87(5): 275-278. ISSN 0033-2097.

Batista, G. R.; Salvadori, F.; Jacobina, C. B.; Freitas, I. S. 2013. Fault tolerant high performance drive system using six-phase induction machine, in Brazilian Power Electronics Conference, Gramado, Brazil, Brazil: 786-792.

Blaschke, F. 1972. The principle of field orientation as applied to the new transvector closed-loop control system for rotating field machines, Siemens Review 39(5): 217-219.

Bojoi, R.; Cavagnino, A.; Tenconi, A.; Vaschetto, S. 2016. Control of shaft-line-embedded multiphase starter/generator for aero-engine, IEEE Transactions on Industrial Electronics 63(1): 641-652.

Bojoi, R.; Tenconi, A.; Vaschetto, S. 2010. Direct stator flux and torque control for asymmetrical six-phase induction motor drives, in IEEE International Conference on Industrial Technology, Vina del Mar, Chile. 1507-1512.

Boldea, I.; Nasar, S. A. 2005. Electric Drives. Second edition. Boca Raton: Taylor \& Francis, CRC Press. 544 p. ISBN 9780849342202.

Bose, B. 2002. Modern Power Electronics and AC Drives. First edition. USA: Elsevier, Prentice Hall PTR. 736 p. ISBN 978-0130167439.

Bose, B. 2006. Power Electronics and Motor Drives. First edition. San Diego: Elsevier, Academic Press. 851 p. ISBN 978-0-12-088405-6.

Bukšnaitis, J. 2012. Electromagnetical efficiency of the six-phase winding, Elektronika ir Elektrotechnika 3(119): 3-6.

Bukšnaitis, J. 2013. Research of electromagnetic parameters of single-layer three-phase and six-phase chain windings, Elektronika ir Elektrotechnika 19(9): 11-14.

Bukšnaitis, J. 2015. Investigation and comparison of three-phase and six-phase cage motor energy parameters, Elektronika ir Elektrotechnika 21(3): 16-20.

Cao, W.; Mecrow, B. C.; Atkinson, G. J.; Bennett J. W.; Atkinson D. J. 2012. Overview of electric motor technologies used for more electric aircraft (MEA), IEEE Transactions on Industrial Electronics 59(9): 3523-3531.

Cavagnino, A.; Tenconi, A; Vaschetto, S. 2015. Experimental characterization of a beltdriven multi-phase induction machine for $48 \mathrm{~V}$ automotive applications: Losses and temperatures assessments, IEEE Transactions on Industry Applications 52(2): 1321-1330. 
Cheng, F.; Yang, H.; Zhao, R.; Zhu, M. 2009. A PWM strategy for six-phase dual stator induction motor fed by two identical voltage source inverters, in International Conference on Electrical Machines and Systems, ICEMS 2009, Tokyo, Japan: 1-4.

Dente, J.; Labrique, F. 1985. Induction motor-current source inverter systems with phase number greater than 3, in 1st European Conference on Power Electronics and Applications EPE'85, Brussels, Belgium, 1985: 3143-3147.

Ditmanson, C.; Hein, P.; Kolb, S.; Molck, J.; Bernet, S. 2014. A New Modular FluxSwitching Permanent Magnet Drive for Large Wind Turbines, IEEE Transactions on Industry Applications 50(6): 3787-3794.

Draou A.; Miloudi A. 2010. A simplified speed controller for direct torque neuro fuzzy controlled induction machine drive based on a variable gain PI controller, in The 4th International Power Engineering and Optimization Conference, PEOCO 2010, Shah Alam, Selangor, Malaysia: 533-538.

Duran, M. J.; Barrero, F. 2015. Recent advances in the design, modeling and control of multiphase machines_-Part II, IEEE Transactions on Industrial Electronics 63(1): 459468.

Duran, M. J.; Gonzalez-Prieto, I.; Bermudez, M.; Barrero, F.; Guzman, H.; Arahal, M. R. 2016. Optimal fault-tolerant control of six-phase induction motor drives with parallel converters, IEEE Transactions on Industrial Electronics 63(1): 629-640.

Gamesa 5.0 MW - Gamesa Technological Corporation S.A. [interaktyvus]. 2013. [žiūrèta 2016 m. rugsejjo 15 d.]. Prieiga per internetą: http://www.gamesacorp.com/recursos/doc/productosservicios/aerogeneradores/catalogo-g10x-45mw.pdf.

Golubev, A. N.; Ignatenko, S. V. 2000. Influence of number of stator-winding phases on the noise characteristics of an asynchronous motor, Russian Electrical Engineering 71(6): 41-46.

Gonzalez-Prieto, I.; Duran, M. J.; Barrero, F. J. 2016. Fault-tolerant control of six-phase induction motor drives with variable current injection, IEEE Transactions on Power Electronics (99): 7894-7903.

Gopakumar, K.; Sathiakumar, S.; Biswas, S. K.; Vithayathil, J. 1984. Modified current source inverter fed induction motor drive with reduced torque pulsations, IEE Proceedings B - Electric Power Applications 131(4): 159-164

Goyal, G. N.; Aware, M. V. 2012. A comparative performance of six-phase nine switch inverter operation with SPWM and SVPWM, in IEEE International Conference on Power Electronics, Drives and Energy Systems, PEDES 2012, Bengaluru, India: 1-6.

Guzman, H.; Duran, M. J.; Barrero, F.; Zarri, L.; Bogado, B.; Gonzalez-Prieto, I.; Arahal, M. R. 2015. Comparative study of predictive and resonant controllers in fault-tolerant five-phase induction motor drives, IEEE Transactions on Industrial Electronics 63(1): 606-617.

Hasse, K. 1969. On the dynamics of speed control of a static AC drive with a squirrelcage induction machine, PhD Dissertation, Tech. Hochsch. Darmstadt. 
Jacobina, C. B.; Miranda, R. S.; Correa, M. B. D. R.; Lima, A. M. N. 2004. Disturbancefree operation of a six-phase AC motor drive system, in IEEE 35th Annual Power Electronics Specialists Conference, PESC 04, 2004, Aachen, Germany, Germany. 925-931.

Jones, M.; Patkar, F.; Levi, E. 2013. Carrier-based pulse-width modulation techniques for asymmetrical six-phase open-end winding drives, IET Electric Power Applications 7(6): 441-452.

Karttunen, J.; Kallio, S.; Peltoniemi, P.; Silventoinen, P. 2015. Current harmonic compensation in dual three-phase PMSMs using a disturbance observer, IEEE Transactions on Industrial Electronics 63(1): 583-594.

Kianinezhad, R.; Mobarakeh, B. N.; Baghli, L.; Betin, F.; Capolino, G. A. 2008a. Modeling and control of six-phase symmetrical induction machine under fault condition due to open phases, IEEE Transactions on Industrial Electronics 55(5): 1966-1977.

Kianinezhad, R.; Alcharea, R.; Nahid, B.; Betin, F.; Capolino, G. A. 2008b. Analysis and evaluation of DTC and FOC in open phase fault operation of six-phase induction machines, in The 14th IEEE Mediterranean Electrotechnical Conference, MELECON 2008, Ajaccio, France: 447-452.

Kim, H.; Shin, K.; Englebretson, S.; Frank, N.; Arshad, W. 2013. Analytical model of multiphase permanent magnet synchronous machines for energy and transportation applications, in IEEE International Electric Machines \& Drives Conference, IEMDC 2013, Chicago, IL, USA: 172-179.

Kohlrusz, G.; Fodor, D. 2011. Comparison of scalar and vector control strategies of induction motors, Hungarian Journal of Industrial Chemistry 39(2): 265-270.

Kominami, T.; Fujimoto, Y. 2004. Dynamic model and control of six-phase spiral motor, in The 8th IEEE International Workshop on Advanced Motion Control, AMC '04, 2004, Kawasaki, Japan: 629-633.

Kong, W.; Huang, J.; Qu, R.; Kang, M.; Yang, J. 2016. Nonsinusoidal power supply analysis for concentrated-full-pitch-winding multiphase induction motor, IEEE Transactions on Industrial Electronics 63(1): 574-582.

Kundrotas, B. 2013. Sutelktosios dvisluoksnès šešiafazės apvijos sudarymas, Mokslas Lietuvos ateitis: elektronika ir elektrotechnika 5(2): 160-163. Vilnius: Technika. ISSN 2029-2341.

Kundrotas, B. 2014. Šešiafazių asinchroninių variklių pereinamųjų vyksmų tyrimas. Daktaro disertacija. Vilniaus Gedimino technikos universitetas. 103 p.

Kundrotas, B.; Lisauskas, S.; Rinkevičienè, R. 2011. Model of multiphase induction motor, Elektronika ir Elektrotechnika 5(111): 111-114. ISSN 1392-1215.

Kundrotas, B.; Petrovas, A.; Rinkevičienè, R.; Smilgevičius, A. 2014. Research of sixphase induction motor windings. Elektronika ir Elektrotechnika 1(20): 15-18. ISSN 13921215.

Leonhard, W. 2001. Control of Electrical Drives. $3^{\text {rd }}$ edition. Berlin: Springer. 460 p. ISBN 3-540-41820-2. 
Levi, E. 2008. Multiphase electric machines for variable-speed applications, IEEE Transactions on Industrial Electronics 55(5): 1893-1909.

Levi, E. 2016. Advances in converter control and innovative exploitation of additional degrees of freedom for multiphase machines, IEEE Transactions on Industrial Electronics 63(1): 433-448.

Levi, E.; Bojoi, R.; Profumo, F.; Toliyat, H. A.; Williamson, S. 2007. Multiphase induction motor drives - a technology status review, IET Electric Power Applications 1(4): 489-516.

Levi, E.; Jones, M.; Vukosavic, S. N. 2006. A series-connected two-motor six-phase drive with induction and permanent magnet machines, IEEE Transactions on Energy Conversion 21(1): 121-129.

Levi, E; Jones, M.; Vukosavic, S. N.; Toliyat, H. A. 2008. Steady-state modeling of seriesconnected five-phase and six-phase two-motor drives, IEEE Transactions on Industry Applications 44(5): 1559-1568.

Lipinskis, T. 2013. Daugiafazių dažnio keitiklių įtampos formavimo metodų analizè, Mokslas - Lietuvos ateitis: elektronika ir elektrotechnika 5(2): 119-123. ISSN 2029-2341.

Lipinskis, T. 2014. Asimetrinis erdvinio vektoriaus moduliavimo metodas šešių fazių įtampai formuoti, Mokslas - Lietuvos ateitis: elektronika ir elektrotechnika 6(2): 168-171. ISSN 2029-2341.

Lipinskis, T.; Baškys, A.; Bleizgys, V.; Platakis, A. 2014. True six-phase space vector modulation scheme with reduced low order harmonics, Elektronika ir Elektrotechnika 9(20): 46-49. ISSN 1392-1215.

Lipinskis, T.; Baškys, A.; Rutkauskas, A. 2013. Six-phase voltage forming method using the largest magnitude space vectors, Elektronika ir Elektrotechnika 19(10): 99-102. ISSN 1392-1215.

Lipinskis, T.; Bleizgys, V. 2016. Šešių fazių dažninės pavaros eksperimentinis tyrimas, Mokslas - Lietuvos ateitis: elektronika ir elektrotechnika 8(3): 339-344. ISSN 2029-2341.

Lipinskis, T.; Zlosnikas, V. 2015. Erdvinių vektorių perjungimo tvarkos ịtaka komutavimo triukšmams dažnio keitiklio išèjimo įtampoje, Mokslas - Lietuvos ateitis: elektronika ir elektrotechnika 7(3): 357-360. ISSN 2029-2341.

Mansour, N.; Djahbar, A.; Mazari, B. 2008. Matrix converter for six-phase induction machine drive system, Acta Electrotechnica et Informatica 8(2): 64-69.

Markadeh, G. R. A.; Soltani, J.; Abjadi, N. R.; Hajian, M. 2009. Sensorless control of a six-phase induction motors drive using FOC in stator flux reference frame, World Academy of Science, Engineering and Technology 58: 890-896.

Metidji, B.; Taib, N.; Baghli, L.; Rekioua, T.; Bacha, S. 2012. Low-cost direct torque control algorithm for induction motor without AC phase current sensors, IEEE Transactions on Power Electronics 27(9): 4132-4139. 
Microsemi. Park, Inverse Park and Clarke, Inverse Clarke Transformations MSS Software Implementation [interaktyvus]. 2013. [žiūrèta 2016 m. rugsèjo 15 d.]. Prieiga per internetą: http://www.microsemi.com/document-portal/doc_view/132799-park-inverse-parkand-clarke-inverse-clarke-transformations-mss-software-implementation-user-guide.

Miranda, R. S.; Toliyat, H. A.; Jacobina, C. B.; Lima, A. M. N. 2007. Short-circuit fault mitigation in six-phase induction machine drives, in IEEE Vehicle Power and Propulsion Conference, VPPC 2007, Arlington, TX, USA: 370-376.

Moghadasian, M.; Kianinezhad, R.; Betin, F.; Capolino, G. A. 2010. Torque ripple minimization in direct torque control of six-phase induction machines using fuzzy inference systems, in XIX International Conference on Electrical Machines, ICCEM 2010, Rome, Italy. 1-6.

Munim, W. N. W. A.; Che, H. S.; Hew, W. P. 2016. Fault tolerant capability of symmetrical multiphase machines under one open-circuit fault, in 4th IET Clean Energy and Technology Conference, CEAT 2016, Kuala Lumpur, Malaysia: 1-6.

Nabi, H. P.; Dadashi, P.; Shoulaie, A. 2011. A novel structure for vector control of symmetrical six-phase induction machines with three current sensors, ETASR - Engineering, Technology and Applied Science Research 1(2): 23-29.

Nanoty, A.; Chudasama, A. R. 2012. Control of designed developed six-phase induction Motor, International Journal of Electromagnetics and Applications 2(5): 77-84.

Nategh, S.; Ghasemi, A.; Kianinezhad, R.; Seifossadat, S. Gh.; Saneie, M. 2008. An improved fuzzy model based sensorless control for six-phase induction machines, in 3rd IEEE Conference on Industrial Electronics and Applications, ICIEA 2008, Singapore, Singapore: 1469-1474.

Nguyen, N. K.; Meinguet, F.; Sandulescu, P.; Semail, E.; Kestelyn, X. 2015. Fault-tolerant operation of an open-end winding five-phase PMSM drive with short-circuit inverter fault, IEEE Transactions on Industrial Electronics 63(1): 595-605.

Oleschuk, V.; Bojoi, R.; Griva, G.; Profumo, F. 2007. Six-phase drives with combined synchronized space-vector modulation, in The International Conference on "Computer as a Tool", EUROCON 2007, Warsaw, Poland. 1864-1871.

Oleschuk, V.; Griva, G. 2009. Synchronous PWM control of dual neutral clamped converters for electric vehicle drive, in International Conference on Clean Electrical Power, 2009, Capri, Italy: 574-579.

Oleschuk, V; Ermuratskii, V. 2014. Combined topology of quad-inverter six-phase motor drive with synchronized PWM, in 16th International Power Electronics and Motion Control Conference and Exposition, PEMC 2014, Antalya, Turkey. 973-978.

Patel, V. I.; Wang, J.; Nugraha, D. T.; Vuletic, R.; Tousen, J. 2015. Enhanced availability of drivetrain through novel multiphase permanent-magnet machine drive, IEEE Transactions on Industrial Electronics 63(1): 469-480. 
Pavithran, K. N.; Parimelalagan, R.; and Krishnamurthy, M. R. 1988. Studies on inverterfed five-phase induction motor drive, IEEE Transactions on Power Electronics 3(2): 224235.

Pitrènas, A. 2014. Modelling of inverter fed six-phase motor. 65-oji moksline ir techniné konferencija studentams ir magistrantams: moksliniu straipsniu rinkinys. Minskas. 417421. ISBN 978-985-530-380-1.

Pitrènas, A. 2017. Srovių sistemos šešiafazèje dažninèje asinchroninèje pavaroje kompensavimas esant poavariniam režimui. Daktaro disertacija. Vilniaus Gedimino technikos universitetas. $103 \mathrm{p}$.

Pitrènas, A.; Uznys, D. 2016. Tranzistorių valdymo signalų vẻlinimo grandinès šešiafaziame dažnio keitiklyje, Mokslas - Lietuvos ateitis: elektronika ir elektrotechnika 8(3): 345-350. ISSN 2029-2341.

Renukadevi, G.; Rajambal, K. 2012. Generalized d-q model of n-phase induction motor drive, International Journal of Electrical, Computer, Energetic, Electronic and Communication Engineering 6(9): 1066-1075.

Renukadevi, G.; Rajambal, K. 2013. Modeling and Analysis of Multi-Phase Inverter Fed Induction Motor Drive with Different Phase Numbers, Transactions on Systems and Control 8(3): 73-80.

Reznik, L. 1997. Fuzzy Controllers. Newness, Printed in Great Britain by Biddles Ltd, Guildford and King's Lynn: 307 p.

Santos, E. C.; Jacobina, C. B.; Rocha, N.; Silva, E. R. C. 2010. Parallel converters supplying a six-phase machine with circulating current cancellation, in IEEE Energy Conversion Congress and Exposition, ECCE 2010, Atlanta, GA, USA. 3883-3888.

Santos, E. C.; Jacobina, C. B.; Silva, O. I. 2011. Six-phase machine drive system with nine-switch converter, in 37th Annual Conference on IEEE Industrial Electronics Society, IECON 2011, Melbourne, VIC, Australia. 4204-4209.

Shao, L.; Hua, W.; Dai, N.; Tong, M.; Cheng, M. 2015. Mathematical modeling of a 12phase flux-switching permanent-magnet machine for wind power generation, IEEE Transactions on Industrial Electronics 63(1): 504-516.

Sheidaei, F.; Sedighizadeh, M.; Mohseni-Zonoozi, S. H.; Alinejad-Beromi, Y. A. 2007. A fuzzy logic direct torque control for induction motor sensorless drive, in 42nd International Universities Power Engineering Conference, UPEC 2007, Brighton, UK. 197-202.

Taheri, A.; Rahmati, A.; Kaboli, S. 2012. Comparison of efficiency for different switching tables in six-phase induction motor DTC drive, Journal of Power Electronics 12(1): 128135.

Toufouti, R.; Meziane, S.; Benalla, H. 2007. Direct torque control for induction motor using intelligent techniques, Journal of Theoretical and Applied Information Technology 3(3): 35-44. 
Vukosavic, S.N.; Jones, M.; Levi, E.; Varga, J. 2005. Rotor flux oriented control of a symmetrical six-phase induction machine, Electric Power Systems Research 75(2-3): 142-152.

Wang, H.; Zhao, R; Cheng, F; Yang, H. 2011. Six-phase induction machine driven by the matrix converter, in International Conference on Electrical Machines and Systems, ICEMS 2011, Beijing, China: 1-5.

Ward, E. E.; Härer, H. 1969. Preliminary investigation of an invertor-fed 5-phase induction motor, Proceedings of the Institution of Electrical Engineers 116(6): 980-984.

Zadeh, L. A. 1965. Fuzzy sets, Information and Control 8(3): 338-353.

Zhang, G.; Hua, W.; Cheng, M.; Liao, J. 2016. Design and comparison of two novel sixphase hybrid-excited flux-switching machines for EV/HEV applications, IEEE Transactions on Industrial Electronics 63(1): 481-493. 


\section{Autoriaus mokslinių publikacijų disertacijos tema sąrašas}

\section{Straipsniai recenzuojamuose mokslo žurnaluose}

Pitrènas, A.; Uznys, D.; Beištaras, D. 2017. Production of Circular Stator Current Trajectory in Multi-Phase Induction Drive Under Open Phase Fault Condition. Balkan Journal of Electrical \& Computer Engineering 5(1): 1-4. ISSN: 2147-284X.

Uznys, D. 2015. Šešiafazio variklio modeliavimas, Mokslas - Lietuvos ateitis: elektronika ir elektrotechnika 7(3): 361-364. ISSN 2029-2341.

Lisauskas, S.; Udris, D.; Uznys, D. 2013. Direct torque control of induction drive using fuzzy controller, Elektronika ir elektrotechnika 19(5): 13-16. ISSN 1392-1215. (Clarivate Analytics Web of Science).

\section{Straipsniai kituose leidiniuose}

Rinkevičienė, R.; Savickienė, Z.; Uznys, D.; Pitrènas, A.; Šlepikas, A. 2017. Scalar control of six-phase induction motor, in Open conference of Electrical, Electronic and Information Sciences (eStream): proceedings of the conference, April 27, 2017, Vilnius, Lithuania / Organized by: Vilnius Gediminas technical university. New York: IEEE, 2017. 16. ISBN 9781538639986. (Clarivate Analytics Web of Science). 



\section{Summary in English}

\section{Introduction}

\section{Formulation of the problem}

Based on scientific literature research multi-phase electric induction machines are gaining interest. These motors have numerous advantages when compared to three-phase induction machines. Main advantages being lower stator phase currents, higher efficiency, lower levels of higher order current harmonics and, most importantly, the ability to reliably continue operation with the loss of one or more stator phases. Control and post-fault condition compensation methods of multi-phase drives are becoming increasingly popular research topics.

The spread of multi-phase machines is limited by absence of multi-phase electric grid. Therefore, they are used in localized systems where three-phase grid voltage is converted to required multi-phase voltage source.

A six-phase induction direct torque controlled drive using fuzzy logic controller is researched in the current thesis. Compensation of post-fault condition effects using scalar control and fuzzy logic controller is researched as well.

\section{Relevance of the thesis}

High reliability of multi-phase machines is the reason of their application in defence and aeronautics industries, nuclear energetics, etc. Growing electric and hybrid cars market is supporting the spread of these machines due to their ability to manage reliable work in post-fault conditions. Research into torque and velocity controlled drives is relevant. 
Compared to normal operating conditions the post fault mode has power loss and distortions in stator current system and magnetic field. Compensation of these aftereffects requires their precise evaluation. Based on scientific literature survey the most common approach is evaluating the aftereffects based on calculation magnetic flux instead of direct measurement. Magnetic flux research is relevant to development of post-fault condition compensation methods.

\section{Object of the research}

The research object is the six-phase electric induction drives control methods designed for normal operating and post-fault conditions.

\section{Aim of the thesis}

The main aim of the thesis is development of six-phase induction drive control methods using fuzzy logic controllers for improved performance of stator currents and magnetic flux production.

\section{Tasks of the thesis}

The aim of this thesis can be achieved by accomplishing these tasks:

1. Development of fuzzy logic controller for direct torque control method that would improve dynamic qualities of a multi-phase drive.

2. Development of search method for finding stator voltage phase angles that are used in of post-fault condition compensation method.

3. Development of controller for compensation of over-currents and elliptic trajectory of stator current resultant vector in post-fault conditions.

\section{Research methodology}

Six-phase motors and drives are researched in this thesis using mathematical modelling. Simulations were carried out using Matlab Simulink software. Experiments of six-phase transients were carried out for normal operating mode and post-fault conditions. Experimental test rig consisted of six-phase induction motor, six-phase voltage source inverter, mechanical load - DC generator, rotary speed and torque sensor, current sensors, magnetic flux sensors, data acquisition board.

Experiments were carried out in Vilnius Gediminas technical university Faculty of electronics Department of automation (recently renamed to Department of electrical engineering). The data acquisition board that was used in research is owned by State research institute Center for Physical Sciences and Technology.

\section{Scientific novelty of the thesis}

The following results that are relevant to Electrical and Electronic engineering field of science were obtained:

1. New controller for direct torque control method of six-phase induction drives using fuzzy logic was developed.

2. New search method for finding stator voltage phase angles that are used in six-phase scalar control drive post-fault condition compensation of 
over-currents and stator current resultant vector trajectory was developed.

3. New controller for compensation of over-currents and elliptical stator current resultant vector trajectory in post-fault conditions using fuzzy logic was developed.

\section{Practical value of the research findings}

Based on this thesis results multi-phase induction drives can be designed and researched. Developed simulation models can be used for multi-phase drive research in real time.

Developed computer models of six-phase induction drives can be used for further research and development of drive control methods.

Developed experimental test rig of six-phase induction frequency drive will be used for future works.

\section{Defended statements}

1. Developed fuzzy logic controller for direct torque control method reduces ripples of electromagnetic torque by $8 \%$ and more, it also reduces ripples of stator's magnetic flux by $26 \%$ and more when compared to typical direct torque control method.

2. Developed search method that consists of objective function, iterations based on vector diagrams and a search algorithm finds stator voltage phase angles that reduce over-currents and ellipticity of stator current resultant vector trajectory in post-fault conditions.

3. Developed fuzzy logic controller for post-fault condition compensation reduces over-currents and ellipticity of stator current resultant vector trajectory using multiple feedback signals.

\section{Approval of the research findings}

The research results are published in 4 scientific publications: one article is printed in a peer-reviewed scientific journals listed in a Clarivate Analytics Web of Science database and having impact factor (Lisauskas et al. 2013); one in international conference proceedings listed in Clarivate Analytics Web of Science database (Rinkevičienè et al. 2017); two articles are printed in peer-reviewed scientific journals listed in other databases (Uznys 2015; Pitrènas et al. 2017).

The research results were given 9 presentations in scientific conferences:

- $\quad$ Lisauskas, S.; Udris, D.; Uznys, D. 2013. Direct Torque Control of Induction Drive Using Fuzzy Controller. 17th International Conference “Elektronika 2013”. Palanga, Lithuania, 17-19 June 2013.

- Uznys, D. 2014. Šešiafazio variklio modeliavimas. 17th Lithuanian conference "Science - Future of Lithuania”. Vilnius, Lithuania, 21 March 2014. 
- Uznys, D. 2015. Šešiafazio variklio valdymas. 18th Lithuanian conference "Science - Future of Lithuania". Vilnius, Lithuania, 20 March 2015.

- Uznys, D. 2016. Šešiafazio variklio gedimo režimo modeliavimas. 19th Lithuanian conference "Science - Future of Lithuania”. Vilnius, Lithuania, 18 March 2016.

- $\quad$ Pitrènas, A.; Uznys, D. 2016. Daugiafazio variklio apskritiminès srovès trajektorijos kūrimas asimetriniu darbo režimu. Open Conference of Electrical, Electronic and Information Sciences, eStream 2016. Vilnius, Lithuania, 19 April 2016.

- Uznys, D. 2017. Modeling of Six-Phase Induction Drives in Post-Fault Conditions. Open Conference of Electrical, Electronic and Information Sciences, eStream 2017. Vilnius, Lithuania, 27 April 2017.

- $\quad$ Rinkevičienè, R.; Savickienė, Z.; Uznys, D.; Pitrènas, A.; Šlepikas, A. 2017. Scalar Control of Six-Phase Induction Motor. Open Conference of Electrical, Electronic and Information Sciences, eStream 2017. Vilnius, Lithuania, 27 April 2017.

- Uznys, D.; Pitrėnas, A.; Beištaras, D.; Lisauskas, S. 2017. Direct Measurement of Six-Phase Induction Drive Magnetic Flux in the Air Gap. 13th International Conference "Mechatronic Systems and Materials". Vilnius, Lithuania, 3-5 July 2017.

- $\quad$ Rinkevičienè, R.; Savickienè, Z.; Lisauskas, S.; Petrovas, A.; Uznys, D.; Pitrènas, A.; Šlepikas, A. 2017. Fuzzy Controllers in Rotor Flux Orientation Control System of Six-Phase Induction Motor. 13th International Conference "Mechatronic Systems and Materials". Vilnius, Lithuania, 3-5 July 2017.

\section{Structure of the dissertation}

The dissertation consists of introduction, three chapters and general conclusions.

The dissertation consists of 98 pages, excluding three annexes. It includes 51 figures, 9 tables, and 48 numerated equations. In total 94 references are cited in the thesis.

\section{Survey and analysis of multi-phase electric drives}

Multi-phase electric machines can be controlled using control methods of the three-phase machines. This includes scalar and vector control methods such as $U / f$ and direct torque control.

In regards to control methods, three-phase machines do not have compensation methods for loss of one or more stator phase. This fault in a three-phase drive results in significant power loss which is not the case for multi-phase drives. Therefore, compensation methods are relevant to multi-phase drives that can maintain reliable operating mode in post-fault conditions.

The typical solution for managing post-fault conditions is disabling three windings that have symmetrical winding distribution, i.e. 120 electrical degrees between phases. 
This keeps the machine symmetric and, therefore, easy to control. Typically, each set of three phases has a separate three-phase source inverter.

This solution is acceptable for multi-phase drives that have great number of phases, e.g. 15 or 21. For drives with low number of windings, such as six-phase machines, this would mean significant power loss. Without more refined compensation methods, multiphase drives are limited to very high powered application such as ship propulsion systems.

Interest in electric cars means increasing interest in average powered multi-phase drives. These have the advantage of reliability in post-fault conditions when compared to three-phase drives. Most faults can be solved by isolating problematic phases, e.g. disabling a short-circuited inverter transistor using fuses.

Aftereffects of loss of one or more stator phases include stator over-currents that can cause further damage to the machine and the inverter. Then there is also ellipticity of rotating magnetic field that increases electric losses and can cause electromagnetic torque ripples. Typically, investigation of rotating magnetic field is limited to calculations based on stator currents. Research based on direct magnetic flux measurement are scarce.

A compensation method for a six-phase frequency drive was developed by researchers of the same department in the university. The main principle is producing source voltage with shifted phase angles, e.g. setting phase angles to $\left[-6^{\circ}, 60^{\circ}, 120^{\circ}, 180^{\circ}, 243^{\circ},-\right]$ instead of the typical $\left[0^{\circ}, 60^{\circ}, 120^{\circ}, 180^{\circ}, 240^{\circ},-\right]$ when sixth phase is lost. Research results proved that stator over-currents were reduced. Ellipticity of stator current resultant vector trajectory was reduced also.

In this thesis the aforementioned post-fault condition compensation method is investigated. A search method for finding source voltage phase angles is developed.

Fuzzy logic is a concept for implementing non-linear controllers based on expert knowledge of the system. By expressing the process in a "if-then" syntax, fuzzy logic controllers are designed and used in all kinds of automatic control systems. They are used for solving various problems when PID controllers and look-up tables are not enough.

\section{Six-phase drive modelling and control in normal operating condition}

Direct torque control (DTC) method is considered a very precise method. It has the advantages of precise speed control when speed feedback is used. It can also be used in sensorless mode when speed feedback is not used and electromagnetic torque is controlled directly. This is a vector control method which does not rely on a PWM generator. The output of control loop is not duty cycle and instead the inverter arms are controlled directly.

Typical DTC method has two input parameters: stator's magnetic flux reference $\Psi_{\text {s,ref. }}(t)$ and electromagnetic torque reference $T_{\text {e,ref. }}(t)$. In standard applications, magnetic flux reference is set to a constant and torque reference is a dynamic value - a feedback signal processed by a PID controller. In typical DTC method these input methods are processed in two steps: firstly, by a dedicated hysteresis bands and, secondly, by a selection table for voltage vector.

Electromagnetic torque and stator's magnetic flux ripples are considered as disadvantages of this control method. In this thesis a controller is designed for reducing these ripples. Fuzzy logic is used. The proposed controller replaces the hysteresis bands and 
vector selection table completely. Functional block diagram of the modified DTC is presented in figure S2.1.

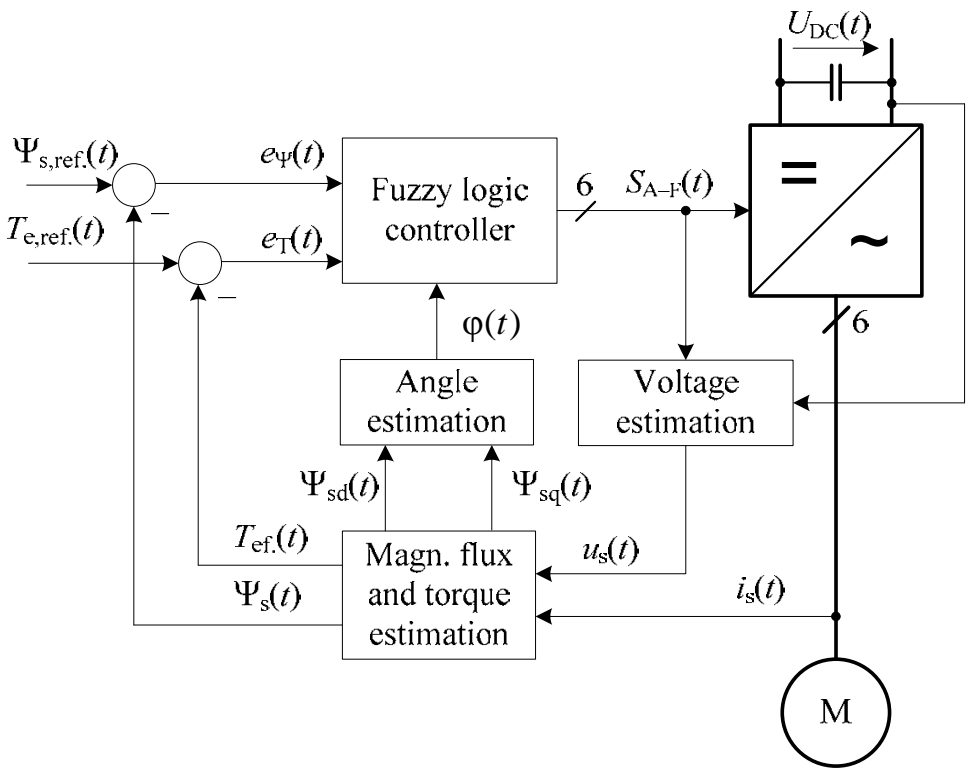

Fig. S2.1. Functional block diagram of direct torque fuzzy control

In figure S2.1, input signals and estimated parameters are exactly the same as in typical DTC scheme. The fuzzy logic controller replaced vector selection but it did keep the same principles of operation. Based on three values - two error values and estimated electromagnetic flux angle - a stator source voltage vector is produced. The vector selection table is used as rules for fuzzy logic controller. It is presented in table S2.1.

Table S2.1. Rules for fuzzy logic controller

\begin{tabular}{|l|l|l|l|l|l|l|l|}
\hline$e_{\Psi}$ & $e_{\mathrm{T}}$ & S. 1 & S. 2 & S. 3 & S. 4 & S. 5 & S. 6 \\
\hline$>1$ & - & $U_{1}$ & $U_{2}$ & $U_{3}$ & $U_{4}$ & $U_{5}$ & $U_{6}$ \\
\hline \multirow{5}{*}{+1} & +1 & $U_{2}$ & $U_{3}$ & $U_{4}$ & $U_{5}$ & $U_{6}$ & $U_{1}$ \\
\cline { 2 - 8 } & 0 & $U_{7}$ & $U_{0}$ & $U_{7}$ & $U_{0}$ & $U_{7}$ & $U_{0}$ \\
\cline { 2 - 8 } & -1 & $U_{6}$ & $U_{1}$ & $U_{2}$ & $U_{3}$ & $U_{4}$ & $U_{5}$ \\
\hline \multirow{3}{*}{-1} & +1 & $U_{3}$ & $U_{4}$ & $U_{5}$ & $U_{6}$ & $U_{1}$ & $U_{2}$ \\
\cline { 2 - 8 } & 0 & $U_{0}$ & $U_{7}$ & $U_{0}$ & $U_{7}$ & $U_{0}$ & $U_{7}$ \\
\cline { 2 - 8 } & -1 & $U_{5}$ & $U_{6}$ & $U_{1}$ & $U_{2}$ & $U_{3}$ & $U_{4}$ \\
\hline$<<-1$ & - & $U_{4}$ & $U_{5}$ & $U_{6}$ & $U_{1}$ & $U_{2}$ & $U_{3}$ \\
\hline
\end{tabular}


In table S2.1, lines 2 to 7 match the typical selection table while lines 1 and 8 are introduced as means of initial stator magnetic flux production and handling of big dynamic flux errors.

Typical DTC and DTC with fuzzy logic controller (DTFC) was simulated in multiple operating conditions:

- $\quad$ soft start with acceleration of $100 \mathrm{rad} / \mathrm{s}^{2}$ (time 0 to $0.5 \mathrm{~s}$ ),

- $\quad$ no-load mode at velocity of $50 \mathrm{rad} / \mathrm{s}$ (time 0.5 to $1.5 \mathrm{~s}$ ),

- $\quad$ load of $25 \mathrm{~N} \cdot \mathrm{m}$ (time 1.5 to $4.5 \mathrm{~s}$ ),

- $\quad$ no-load mode (time 4.5 to $5.5 \mathrm{~s}$ ),

- $\quad$ breaking with deceleration of $100 \mathrm{rad} / \mathrm{s}^{2}$ (time 5.5 to $6.0 \mathrm{~s}$ ).

DTC input signals are identical in both cases: stator's magnetic flux reference is set to $0.7 \mathrm{~Wb}$ and electromagnetic torque reference is set by PID control of speed feedback signal. This PID controller is designed for speed control performance and maximum simulated speed error is $1 \%$. Simulated electromagnetic torque shows that the ripples are reduced when fuzzy logic controller is used. These simulation results are presented in figure S2.2.

a)
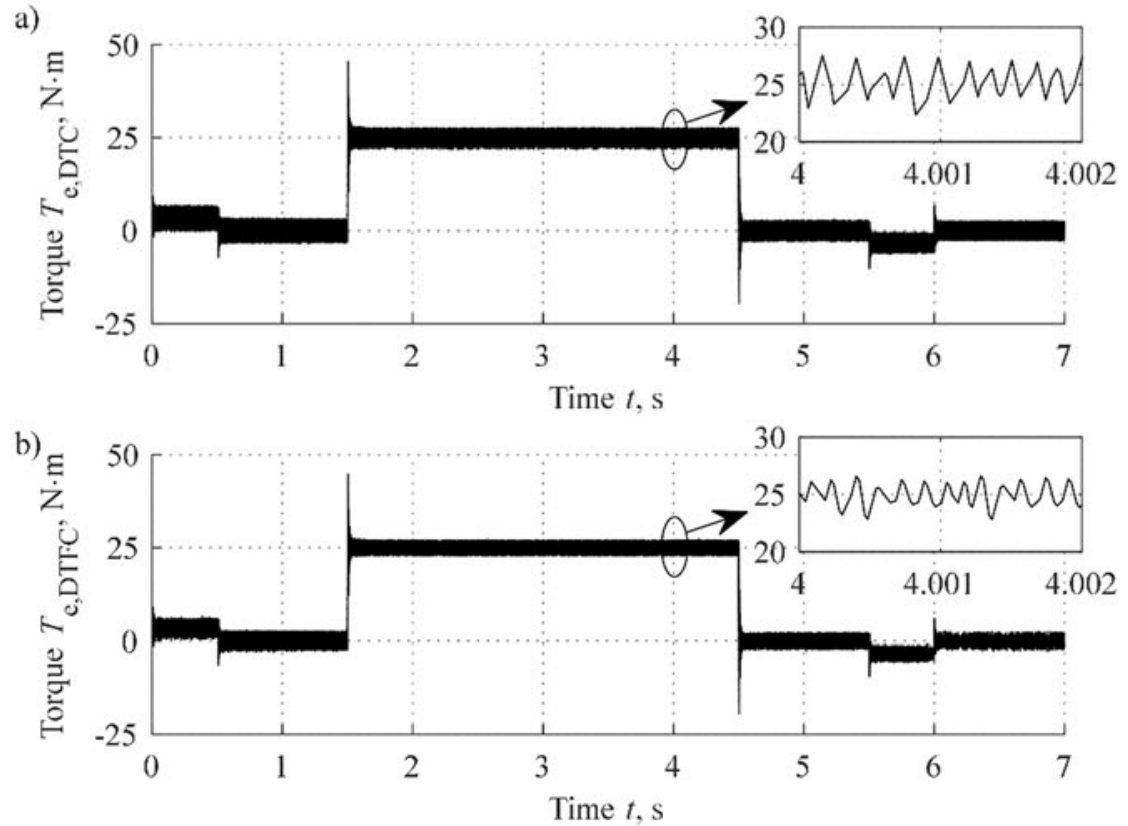

Fig. S2.2. Simulated electromagnetic torque transients of drive using vector control: a) typical direct torque control; b) direct torque control with fuzzy logic controller 
In figure S2.2, electromagnetic torque response is consistently better in DTFC method as seen by the oscillation amplitude. Stator's magnetic flux response shows similar results. This is presented in figure S2.3.

a)

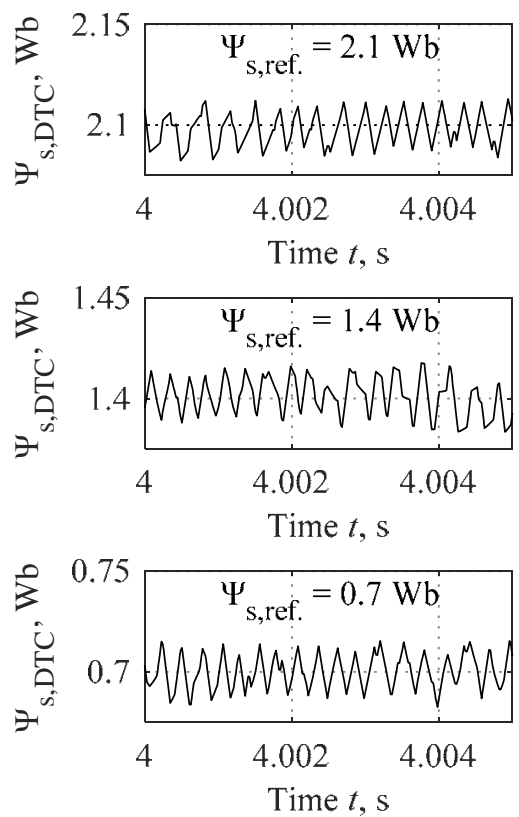

b)
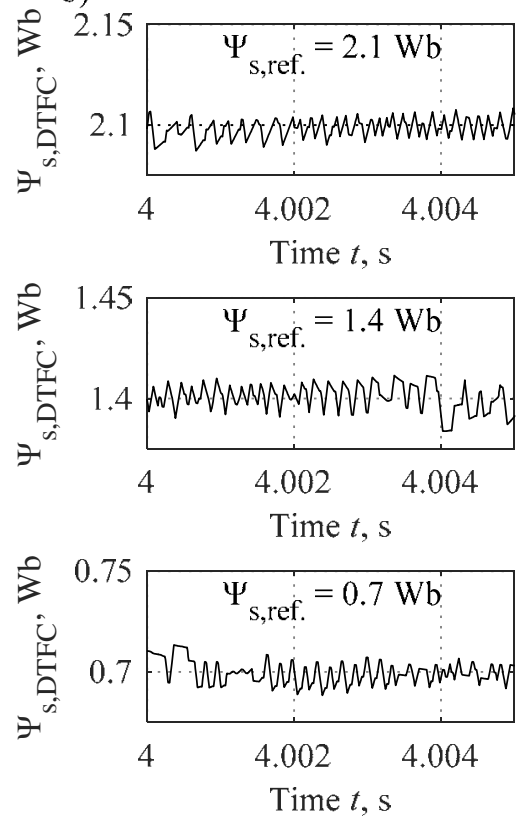

Fig. S2.3. Simulated stator magnetic field vector trajectories: a) typical direct torque control; b) direct torque control with fuzzy logic controller

In figure S2.3, more simulation results are presented. Three reference values are simulated: small of $0.7 \mathrm{~Wb}$, medium of $1.4 \mathrm{~Wb}$ and big of $2.1 \mathrm{~Wb}$. In these conditions stator's magnetic flux error seems smaller in DTFC. The quality is measured by calculating deviations:

$$
\begin{gathered}
\sigma_{\Psi}=\frac{1}{N} \sum_{k=1}^{N}\left|e_{\Psi}(k T)\right|, \\
\sigma_{\mathrm{T}}=\frac{1}{N} \sum_{k=1}^{N}\left|e_{\mathrm{T}}(k T)\right| .
\end{gathered}
$$

Formulas S2.1 and S2.1 are used for calculating deviations of the whole process including soft starting, loading and soft braking. Simulation results of three different stator's magnetic flux set-points are presented in table S2.2. 
Table S2.2. Comparison table for magnetic flux and torque transients

\begin{tabular}{|l|l|l|l|l|l|l|}
\hline \multirow{2}{*}{$\begin{array}{l}\text { Magnetic } \\
\text { flux refer- } \\
\text { ence }\end{array}$} & \multicolumn{4}{|l|}{ Magnetic flux deviation, Wb } & \multicolumn{3}{l|}{ Torque deviation, N·m } \\
\cline { 2 - 7 } & DTC & DTFC & Ratio & DTC & DTFC & Ratio \\
\hline $2.1 \mathrm{~Wb}$ & 0.0068 & 0.0045 & $65 \%$ & 3.63 & 3.34 & $92 \%$ \\
\hline $1.4 \mathrm{~Wb}$ & 0.0068 & 0.0044 & $65 \%$ & 2.25 & 2.05 & $91 \%$ \\
\hline $0.7 \mathrm{~Wb}$ & 0.0068 & 0.0051 & $74 \%$ & 1.02 & 0.75 & $74 \%$ \\
\hline
\end{tabular}

DTC with fuzzy logic controller has consistently better performance (table S2.2). Magnetic flux deviations are reduced by 26 to 35\% and electromagnetic torque ripples are reduced by 8 to $26 \%$.

\section{Six-phase drive control in post-fault conditions}

A compensation method for aftereffects of multi-phase induction drive in post-fault conditions was proposed in (Pitrènas et al. 2018). This method can reduce stator over-currents and ellipticity of stator current resultant vector trajectory when one or more stator phases are open in a frequency drive. This is achieved by producing stator source voltages with phase angles other than standard. Voltage amplitudes are kept constant.

In this thesis the aforementioned compensation method is investigated by performing direct measurement of magnetic flux densities in the six-phase machine air-gap. Positions of the flux density sensors (Hall effect sensors) are important. The experimental six-phase machine had 4 pole pairs and, therefore, sensor placement positons are as in figure S3.1.

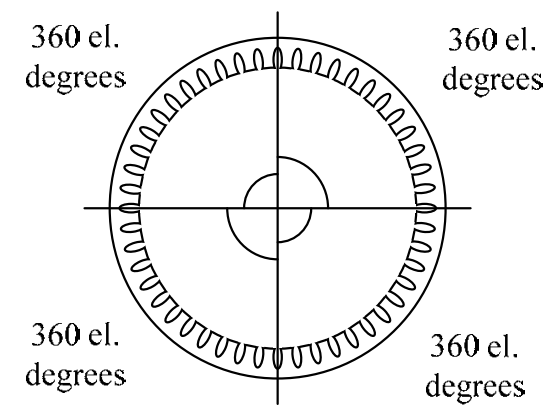

a)

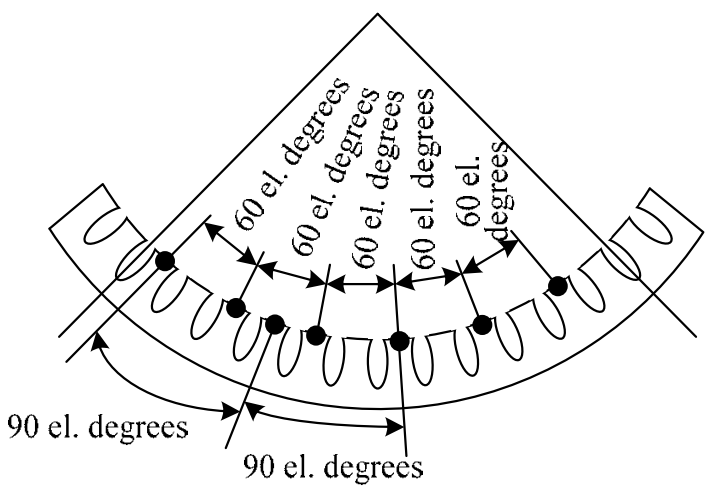

b)

Fig. S3.1. Motor stator cross-section: a) electric angles of stator with four pole pairs; b) positions of magnetic flux sensors in the magnetic circuit

Stator cross-section is split into four segments of 360 electrical degrees (fig. S3.1 part a). All sensors are placed in one segment. They are positioned at electrical angle of 
60 electrical degrees between adjacent sensors (fig. S3.1 part b). In order to measure magnetic flux density in the air-gap, each sensor is in a special slot in the stator's magnetic circuit.

Sensor voltage signals have high levels of low frequency noise. Using fast Fourier transform (FFT), amplitude spectrums are calculated. They presented in figure S3.2.

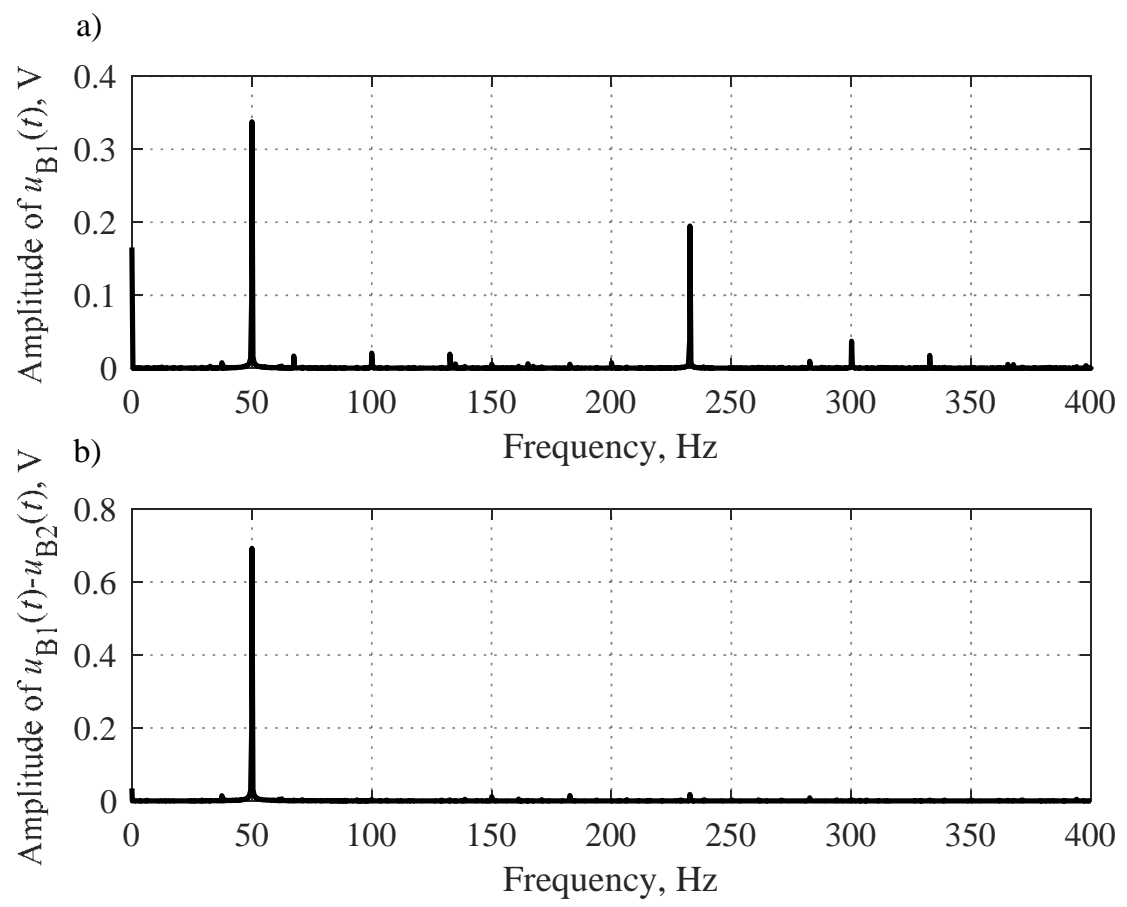

Fig. S3.2. Amplitude spectrums: a) single magnetic flux measurement voltage; b) difference of two magnetic flux measurement voltages with phase shift of $180^{\circ}$

In figure S3.2 part a, high levels of noise are visible $-0.195 \mathrm{~V}$ at frequency $238 \mathrm{~Hz}$ versus $0.338 \mathrm{~V}$ at main source voltage frequency of $50 \mathrm{~Hz}$. They are compensated by calculating difference between two signals of sensors with 180 electrical degree angle. Result is presented in figure S3.2 part b. This signal is then digitally filtered to remove high frequency noise and the scaled result is magnetic flux density in the air-gap at a single direction.

Six sensors are used (fig. S3.1 part b) to measure magnetic flux densities in three directions that have 120 electrical degree angle. This set of magnetic flux density measurements is compared with stator currents measurements. For comparison results are presented in figure S3.3 as resultant vector trajectories and amplitude spectrums of vector lengths. 
a)

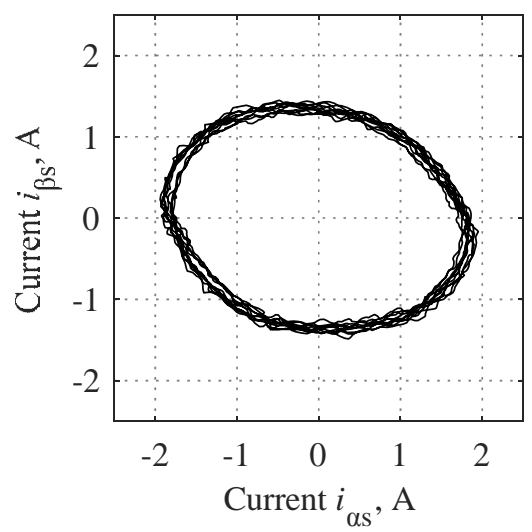

c)

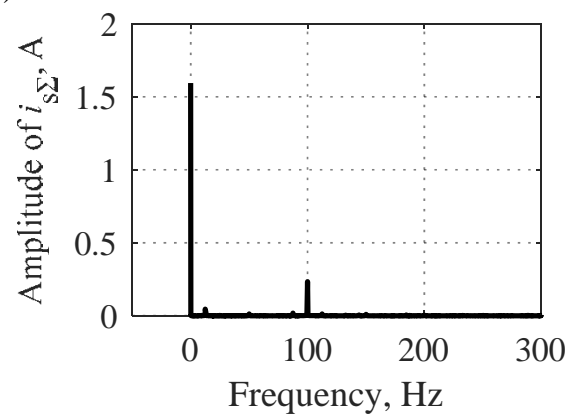

b)
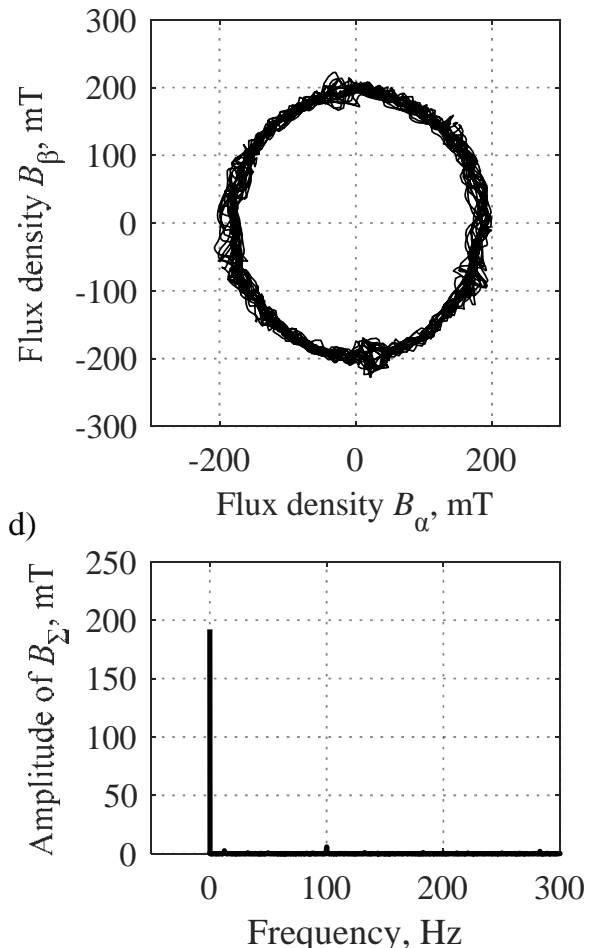

Fig. S3.3. Experimental resultant vector values in uncompensated post-fault condition (loss of phase F): a) resultant vector trajectory of stator currents; b) resultant vector trajectory of magnetic flux densities in the air gap; c) resultant vector length amplitude spectrum of stator currents;

d) resultant vector length amplitude spectrum of magnetic flux densities in the air gap

In figure S3.3, post-fault condition of one open phase are analysed. As expected, stator current resultant vector trajectory is elliptical as opposed to circular trajectory in normal operating condition (fig. S3.3 part a). In amplitude spectrum of figure S3.3 part c, trajectory ellipticity manifests as $100 \mathrm{~Hz}$ spectrum component - it is $15 \%$ of $0 \mathrm{~Hz}$ spectrum component.

In case of magnetic flux density resultant vector trajectory (fig. S3.3 parts b and d), ellipticity is a lot lower. Amplitude of $100 \mathrm{~Hz}$ spectrum component is $3 \%$ of $0 \mathrm{~Hz}$ spectrum component. This is a very low impact of one open phase post-fault condition when compared to stator current qualities.

In compensation method the stator source voltage phase angles are changed to reduce ellipticity of stator current resultant vector trajectory and reduce stator over-currents. The effects on magnetic flux qualities are presented in figure S3.4. 
a)

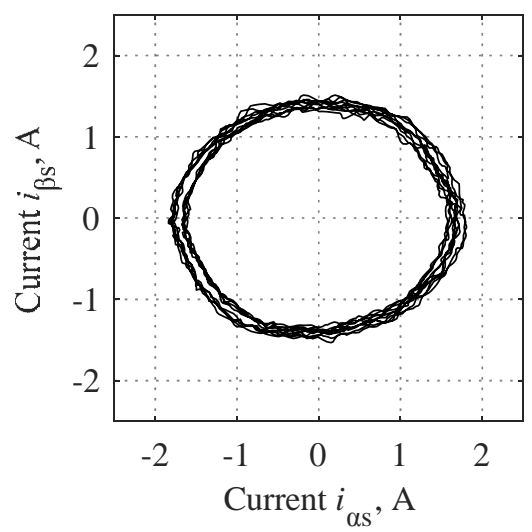

c)

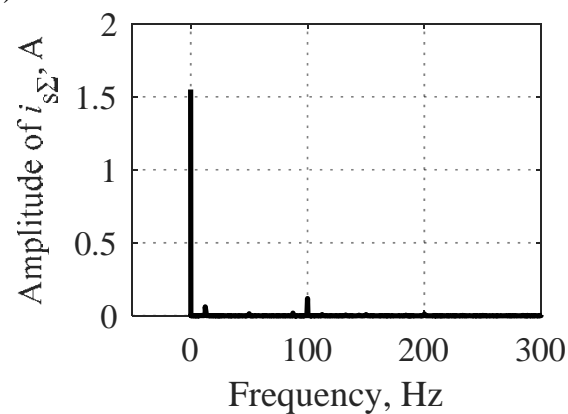

b)
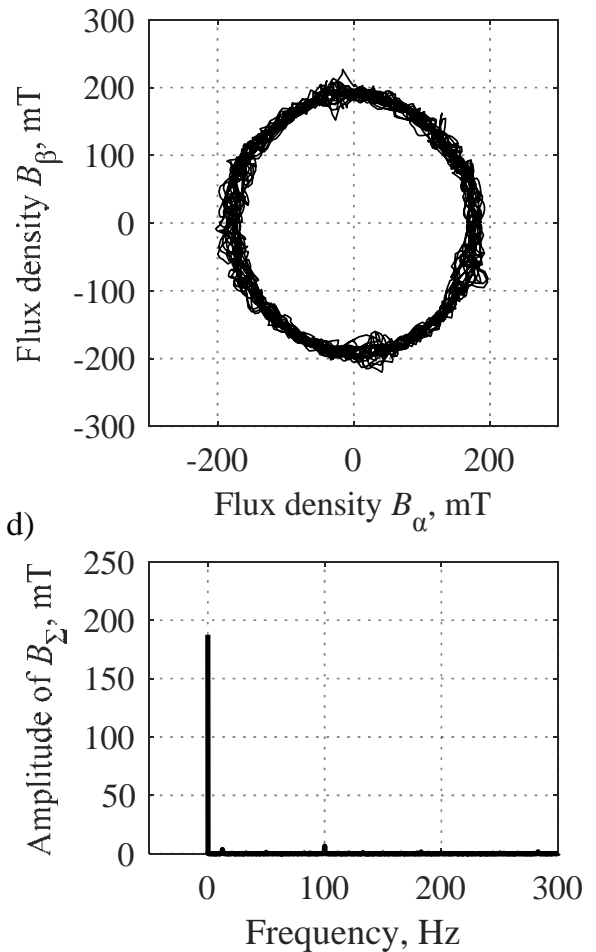

Fig. S3.4. Experimental resultant vector values in over-current-compensated post-fault condition (loss of phase F): a) resultant vector trajectory of stator currents; b) resultant vector trajectory of magnetic flux densities in the air gap; c) resultant vector length amplitude spectrum of stator currents; d) resultant vector length amplitude spectrum of magnetic flux densities in the air gap

In figure S3.4, partial compensation of over-currents and ellipticity of trajectory shows positive results on current qualities. Magnetic flux density in the air-gap is affected very little (fig. S3.4 parts b and d). It can be concluded that this compensation method does not have negative side effects on the magnetic flux density resultant vector trajectory.

In this thesis a search method for stator source voltage phase angles is developed. A single set of phase angles is not suitable for compensation in different operating conditions. For example, the frequency drive can be speed-controlled. Experiments show that stator current system qualities change when source voltage frequency is different. Same goes for load conditions and other less significant parameters.

A single solution can be found by blindly performing numerous experiments and that is acceptable. However, there is a need for multiple phase angle sets to cover a wide range of operating conditions. Systematic search is must be performed. 
Based on vector diagrams of stator currents and voltages, a search method was developed. Iteration for compensating ellipticity of vector trajectory is presented in figure S3.5.

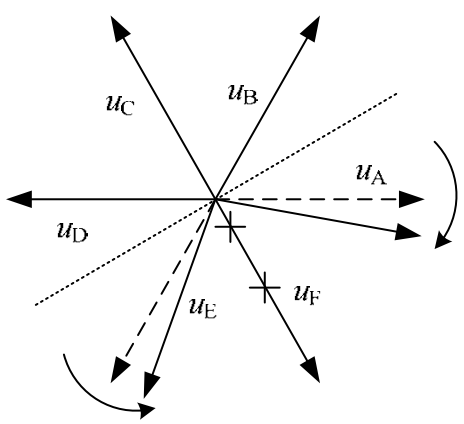

a)

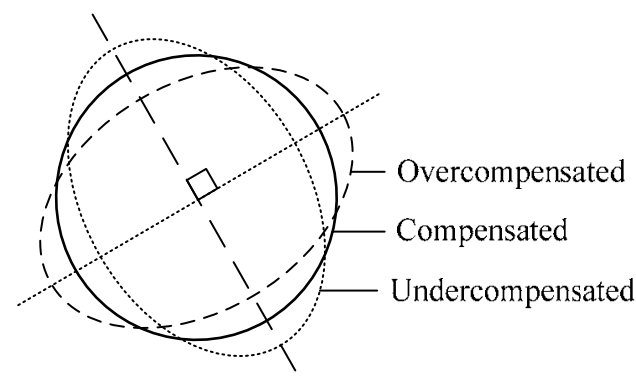

b)

Fig. S3.5. Compensation for trajectory of stator current resultant vector by means of shifting generated stator voltage phase angles: a) approach by shifting of two phase angles closer to the lost phase; b) trajectories of stator current resultant vector before and after compensation

In case phase F is open (fig. S3.5 part a), the ellipse direction of stator current resultant vector trajectory is close to that of open phase (see undercompensated in fig. S3.5 part b). By shifting voltage phase angles closer to the lost phase (fig. S3.5 part a), the ellipticity can be reduced and in ideal case - trajectory can be restored to circular.

Over-currents can be compensated by shifting voltage angles based on stator current vector diagram when greatest over-current or lowest under-current is identified. See full thesis for complete list of proposed iterations.

An objective function is required for assessing effects of each search iteration. The developed objective function consists of three components that rate ellipticity, over-currents and trajectory radius:

$$
\begin{aligned}
& f\left(e, I_{\mathrm{A}}, I_{\mathrm{B}}, I_{\mathrm{C}}, I_{\mathrm{D}}, I_{\mathrm{E}}\right)= \\
& e+k \cdot \frac{\sigma\left(I_{\mathrm{A}}, I_{\mathrm{B}}, I_{\mathrm{C}}, I_{\mathrm{D}}, I_{\mathrm{E}}\right)}{I_{\text {mean }}}+\left(\frac{I_{\text {norm.o.c. }}-I_{\text {mean }}}{I_{\text {norm.o.c. }}}\right)^{2},
\end{aligned}
$$

where $e$ is ellipticity of stator current resultant vector trajectory, $\sigma$ is standard deviation, $I_{\mathrm{A}-\mathrm{E}}$ are amplitudes of stator phase currents, $I_{\text {mean }}$ is mean value of stator phase current amplitudes, $I_{\text {norm.o.c. }}$ is mean value of stator phase current amplitudes in normal operating condition, $k$ is weight of over-current objective component.

The weight $k$ in formula S3.1 is set to 5 . With this value, first and second components are equal in uncompensated post-fault condition when one phase is open.

Third component has the lowest weight when in normal circumstances. The applied search algorithm does not necessarily have to be the proposed one in order for objective 
function to work. In case phase angles shifts are very great, the stator current may drop significantly. Then the third component in objective function (formula S3.1) will be the greatest of all components and, therefore, indicate bad result.

A search algorithm was developed. It is presented in figure S3.6.

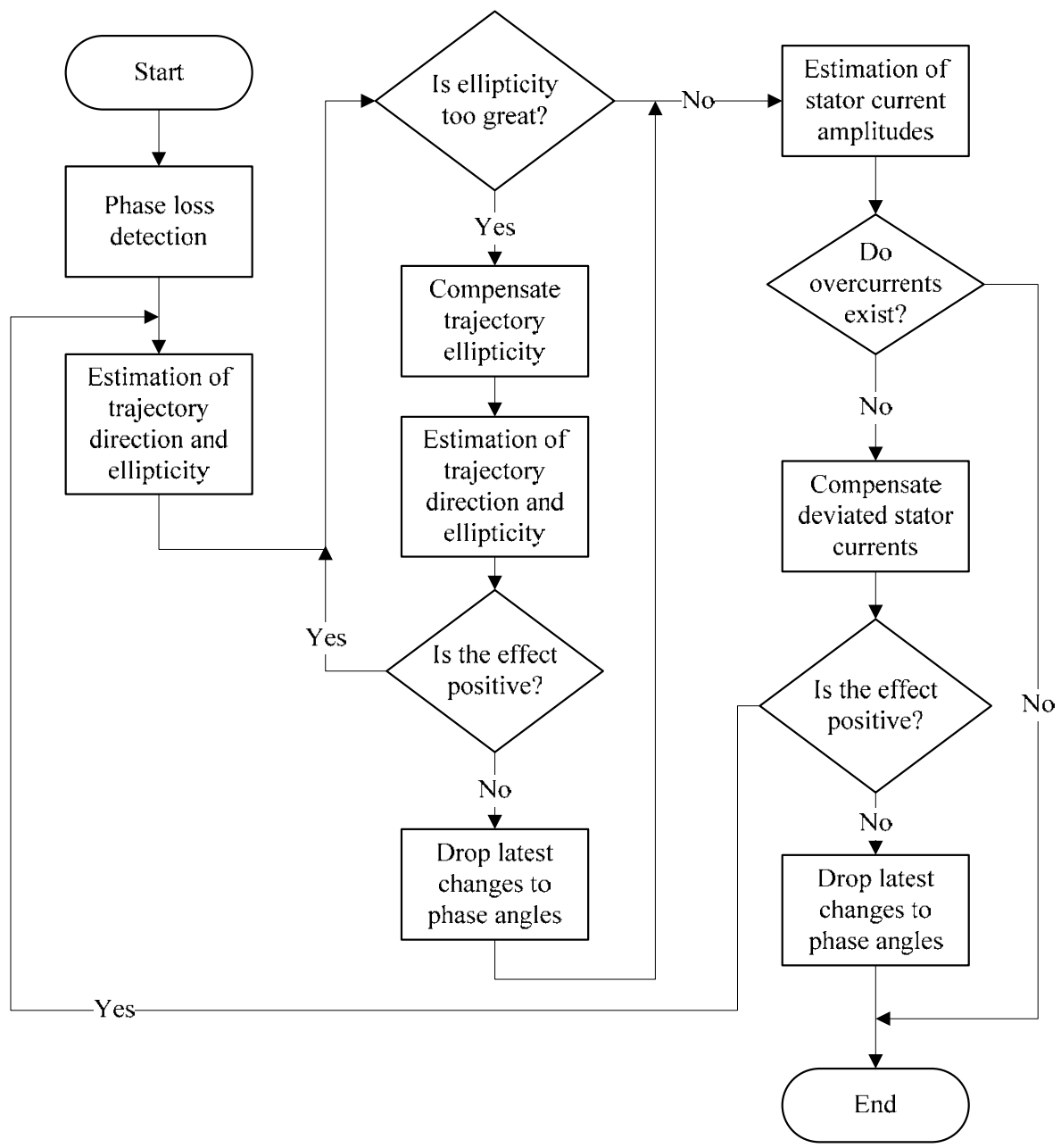

Fig. S3.6. Search algorithm for stator voltage phase angles

Search algorithm in figure S3.6 has two loops. First loop is meant to compensate ellipticity of vector trajectory. Second loop is mean to compensate over-currents. Each loop is escaped when a threshold is met or the last iteration is worse than the one before. Firstly, the ellipticity is compensated. Then an iteration for over-current compensation is performed. Next, the ellipticity is re-estimated and cycle repeats. 
When multiple stator source voltage phase angle sets are found, they should be applied to the frequency drive for post-fault condition compensation in a wide range of operating conditions. With multiple parameters in consideration, a more sophisticated solution than a look-up table is necessary. A fuzzy logic compensator is proposed. Designed fuzzy logic controller is presented in figure S3.7.

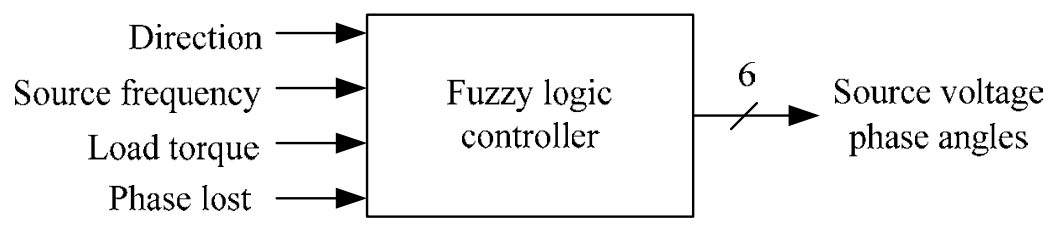

Fig. S3.7. Functional block diagram of post-fault condition compensator

A fuzzy logic controller for multiple input parameters is designed (fig. S3.7). These parameters are direction, source voltage fundamental frequency, load torque and number of phase lost. Parameters for the controller should be selected by considering frequency drive applications. Any number of parameters can be added or removed from the fuzzy logic controller.

Matlab package Fuzzy Logic Toolbox was used for designing the controller. A training data set is prepared with the stator source voltage phase angles found by manual or automated search. A training data table for single lost phase is presented in table S3.1.

Table S3.1. Source voltage phase angle selection table when stator phase F is open

\begin{tabular}{|l|l|l|l|l|l|l|l|l|}
\cline { 4 - 9 } \multicolumn{2}{c}{} & \multicolumn{7}{l|}{ Source voltage phase angles, ${ }^{\circ}$} \\
\hline Direction & $\begin{array}{l}\text { Source frequency, } \\
\text { Hz }\end{array}$ & $\begin{array}{l}\text { Load torque, } \\
\text { N·m }\end{array}$ & A & B & C & D & E & F \\
\hline Forward & 50 & 0.5 & 3 & 63 & 120 & 180 & 245 & 300 \\
\hline Forward & 50 & 2.5 & 3 & 64 & 120 & 178 & 244 & 300 \\
\hline Forward & 30 & 0.5 & 2 & 62 & 120 & 180 & 244 & 300 \\
\hline Forward & 30 & 2.5 & 2 & 63 & 120 & 178 & 243 & 300 \\
\hline Backward & 30 & 0.5 & 356 & 60 & 120 & 178 & 238 & 300 \\
\hline Backward & 30 & 2.5 & 357 & 62 & 120 & 177 & 238 & 300 \\
\hline Backward & 50 & 0.5 & 355 & 60 & 120 & 177 & 237 & 300 \\
\hline Backward & 50 & 2.5 & 356 & 62 & 120 & 176 & 237 & 300 \\
\hline
\end{tabular}

In table S3.1 there are 8 phase angle sets for a single lost phase. In a six-phase drive, full table would consist of 48 sets. The output signals are the source voltage phase angles. 
The experimental drive was limited to voltage phase angle increments of 1 degree. In this case, the outputs of fuzzy logic controller must be quantified.

\section{General conclusions}

1. Developed fuzzy logic controller for direct torque control method replaces hysteresis band controllers and voltage vector selection table. It improves dynamic qualities of six-phase drives when compared to typical direct torque control.

2. Problem of initial magnetic field production was solved and magnetic flux overshoot was limited using fuzzy logic for direct torque control drive.

3. Direct torque control with fuzzy logic controller compared to typical direct torque control method improves dynamic qualities - ripples of electromagnetic torque are reduced by $26 \%$ and that of stator's magnetic field by $26 \%$ when magnetic field set-point is small $(0.7 \mathrm{~Wb})$. When the set-point is great $(2.1 \mathrm{~Wb})$ ripples of electromagnetic torque are reduced by $8 \%$ and that of stator's magnetic field by $35 \%$.

4. It was found that rotating magnetic field in the air-gap is close to circular. These experimental results were obtained when one or two adjacent stator phases of a six-phase motor are open.

5. In post-fault condition, elliptical rotating magnetic field in the air-gap was restored to circular rotating field when using stator phase angles found by executing search which is based on stator current and voltage diagrams.

6. Over-currents were reduced by $9 \%$ in fourteen iterations of proposed search. When using general purpose search method such as simplex search the number of iterations would be a lot greater and search of five parameters may be unsuccessful.

7. Technique for designing fuzzy logic controllers was developed. Such controller is able to reduce over-currents and ellipticity of rotating magnetic field in the air-gap in post-fault conditions with one or more open stator phases of a multi-phase frequency drive. 
Priedai $^{3}$

A priedas. Disertacijos autoriaus sąžiningumo deklaracija

B priedas. Bendraautorių sutikimai teikti publikaciju medžiagą disertacijoje

C priedas. Autoriaus mokslinių publikacijų disertacijos tema kopijos

${ }^{3}$ Priedai pateikiami pridètoje kompaktinèje plokštelëje. 


\section{Donatas UZNYS}

NERAIŠKIĄJA LOGIKA GRĮSTAS ŠEŠIAFAZIŲ ASINCHRONINIŲ PAVARŲ VALDYMAS

Daktaro disertacija

Technologijos mokslai, elektros ir elektronikos inžinerija (01T)

\section{FUZZY LOGIC BASED SIX-PHASE} INDUCTION DRIVE CONTROL

Doctoral Dissertation

Technological Sciences,

Electrical and Electronic Engineering (01T)

201806 12. 11,0 sp. I. Tiražas 20 egz.

Vilniaus Gedimino technikos universiteto

leidykla „Technika“,

Saulètekio al. 11, 10223 Vilnius,

http://leidykla.vgtu.lt

Spausdino Bl UAB „Baltijos kopija“

Kareivių g. 13B, 09109 Vilnius 